\title{
5
}

\section{COMPETITION AND VISIONS}

\begin{abstract}
At a recent meeting on the construction of Magnitogorsk at the Building Committee of the Russian Republic, the workers of Magnitogorsk asked: was it possible to undertake experimental construction not at Magnitogorsk but at some other site? It turned out that arguments about the plan had completely stopped construction, there was nothing they could do about it, and come next year there simply would not be room enough for everyone. If you asked why this was happening you would receive the following answer: because each person carries into Magnitogorsk his own new project for the socialist city expecting the concretization of it at the current moment, and each chooses not to see that the resolution of that question is impossible.
\end{abstract}

-G. V. PuZIS (1929)

The Gosplan economist G. V. PuZis was Sent to MagnitogorsK in the Second half of 1929 to revise the economic plan of the city. In his speech at Gosplan's November conference on socialist settlement, Puzis described to his colleagues the chaos and confusion he encountered on the Ural steppe. Magnitogorsk, he reflected, seemed weighed down with too many irreconcilable ambitions. Workers justifiably worried that disagreements about conceptual Magnitogorsk-the experimental socialist city being shaped through debate by theorists like Leonid Sabsovich and Mikhail Okhitovich-only served to attenuate provisionality in actual, material Magnitogorsk. While a collection of officials in Moscow drafted the brief for the most important design competition of the first Five-Year Plan for an end-of-1929 release, construction workers and their families were living on the site of the future steel city in dugouts, tents, yurts, and single-room barracks.

Magnitogorsk's origin story has been told myriad times and with great archival depth. ${ }^{1}$ This particular narrative focuses on the conceptual version of Magnitogorsk that emerged in text and drawings in late 1929 and early 1930. It forges 
links between the socialist urbanism debates roiling in Moscow, the drafting of the Magnitogorsk design competition brief, and the competition entries submitted for the most prominent new socialist city in the Union. Although the natural outcropping of iron ore known as Magnetic Mountain, and the Iron and Steel Works, were the prime reasons for the site's development, they sit distantly in the background of this portion of the Magnitogorsk story, as they did for the designers drafting competition submissions in other Soviet cities distant from the Urals. ${ }^{2}$

The All-Union Open Design Competition for Magnitogorsk, announced at the end of December 1929, elicited proposals for the design and construction of a socialist city adjacent to the metallurgical plant in the Urals, and for typical residential communes. The brief was exhaustively detailed: the competition entries would test the possibilities of byt transformation in urban and architectonic form and would materialize the programs and relationships discussed in the socialist urbanism debate. To understand the role this competition brief played in the evolution of the socialist spatial project requires borrowing a concept-the instaurational text-from the urban historian Françoise Choay. Choay defines the instaurational text as a written framework for constructing new spaces; it is intellectual work that spawns physical worlds. ${ }^{3}$ By following the conceptual apparatus of the competition brief, it was believed, Soviet designers would finally provide to the jury and public alike images of the new socialist world that could be examined, assessed, critiqued, and hopefully, embraced.

\section{Arrival at the Mountain}

Magnitogorsk was born in 1918. In April of that year Vesenkha announced a competition to design a metallurgic plant in the Urals modeled on the US Steel Plant in Gary, Indiana. This mythic plant would produce "all of the steel that Russia might need." Although it is unclear whether the competition ever occurred-the Russian Civil War began and further information has been lost-the giant iron-ore mountain and the territory surrounding it became lodged in Soviet imaginations as critical to autarkic industrial goals. Work on the Magnitogorsk Iron and Steel Works restarted in 1926 with the establishment of the State Institute for the Design of Metallurgical Factories (Gipromez), but lack of internal technical expertise hamstrung the project from its inception. ${ }^{5}$ In 1927, Vesenkha engaged the Chicago-based design-engineering firm Henry Freyn and Co., the company responsible for designing the Gary plant that Magnitogorsk strove to emulate, as technical consultants for the burgeoning Soviet metallurgical industry. ${ }^{6}$ Design work on Magnitogorsk commenced in the Leningrad office of Gipromez with the assistance of Freyn engineers, while a parallel effort continued at the Urals branch of Gipromez, an office that would soon be renamed Magnitostroi. 
The site for the future factory city was determined by a geological anomaly: a mountain made almost entirely of iron ore that sat alone in the middle of the steppe. As it developed, unplanned, the production zone for the Magnitogorsk Iron and Steel Works consisted of the mountain, a mine to its immediate north, the factory site to the west of the mine, a rail yard nestled between mine and factory, and an industrial lake along the whole western edge, created by damming the Ural River at the city's southern border (figure 5.1). Rail lines marked the city's northern edge, heading west to Ufa, east to Kartaly. In the absence of planning, workers' residential accommodations-such as they were-sprung up within the production zone, in a slice of land between the mine and factory territories.

In March 1929, the first twenty-five people arrived in Magnitogorsk. Through that year, the only construction activity at the site consisted of laying track to connect with the nearest rail station 145 kilometers away, building a small brick

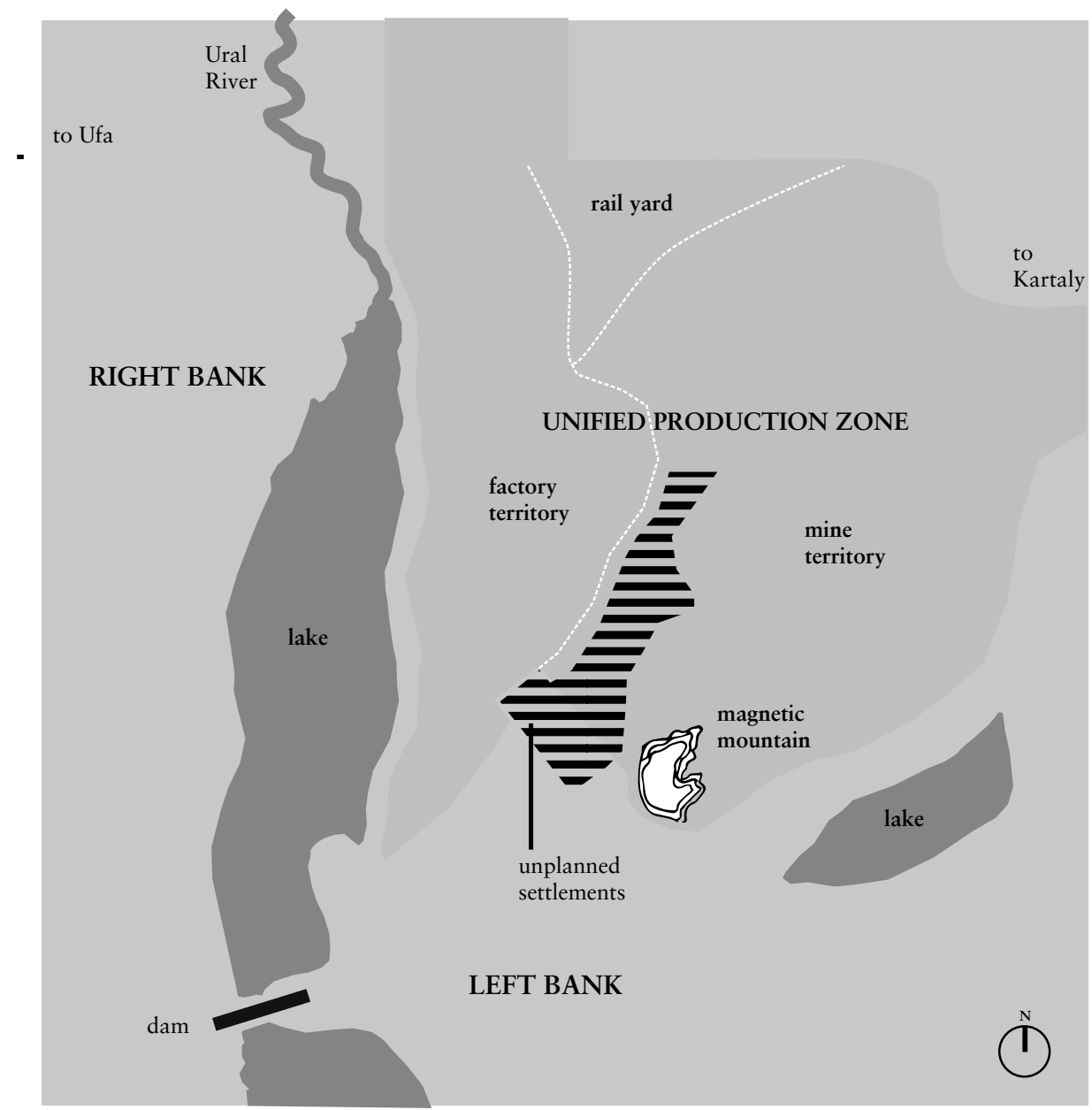

Figure 5.1. Magnitogorsk, 1930. Map by the author, adapted from Sovetskaia arkhitektura, no. 3 (1933): 29. 
factory, and a few wooden barracks. By the end of 1929 there were purportedly already 6,763 workers on the factory site, a population number that did not account for their family members or people not working in construction. ${ }^{7}$

Magnitogorsk at the turn of the decade was a site of extremes, on which the openness of the windswept steppe contrasted unfavorably with crowded, poorly built living quarters. Workers and their families who were either enticed or forced to make the long trip to the construction site found no proper living quarters on arrival, a problem that intensified with the precipitously expanding population. ${ }^{8}$ Photographs show the housing options that were made available to this population or that were built by the workers themselves. For families, the most private option was a stand-alone "dugout" house, constructed from turf harvested on the steppe (figure 5.2). For singles, the administration pitched a tent city and built wooden barracks, while some enterprising workers constructed their own yurts (figure 5.3). S. Gugel', director of Magnitostroi in the later 1930s, estimated that just forty-three proper residential buildings-wooden barracks-were built in the winter of 1929-30 to accommodate a population upward of 10,000 residents (figure 5.4). As it was, the open-plan barracks housed not just the sleeping quarters of workers and engineers but also socialist organizations, banks, the municipal

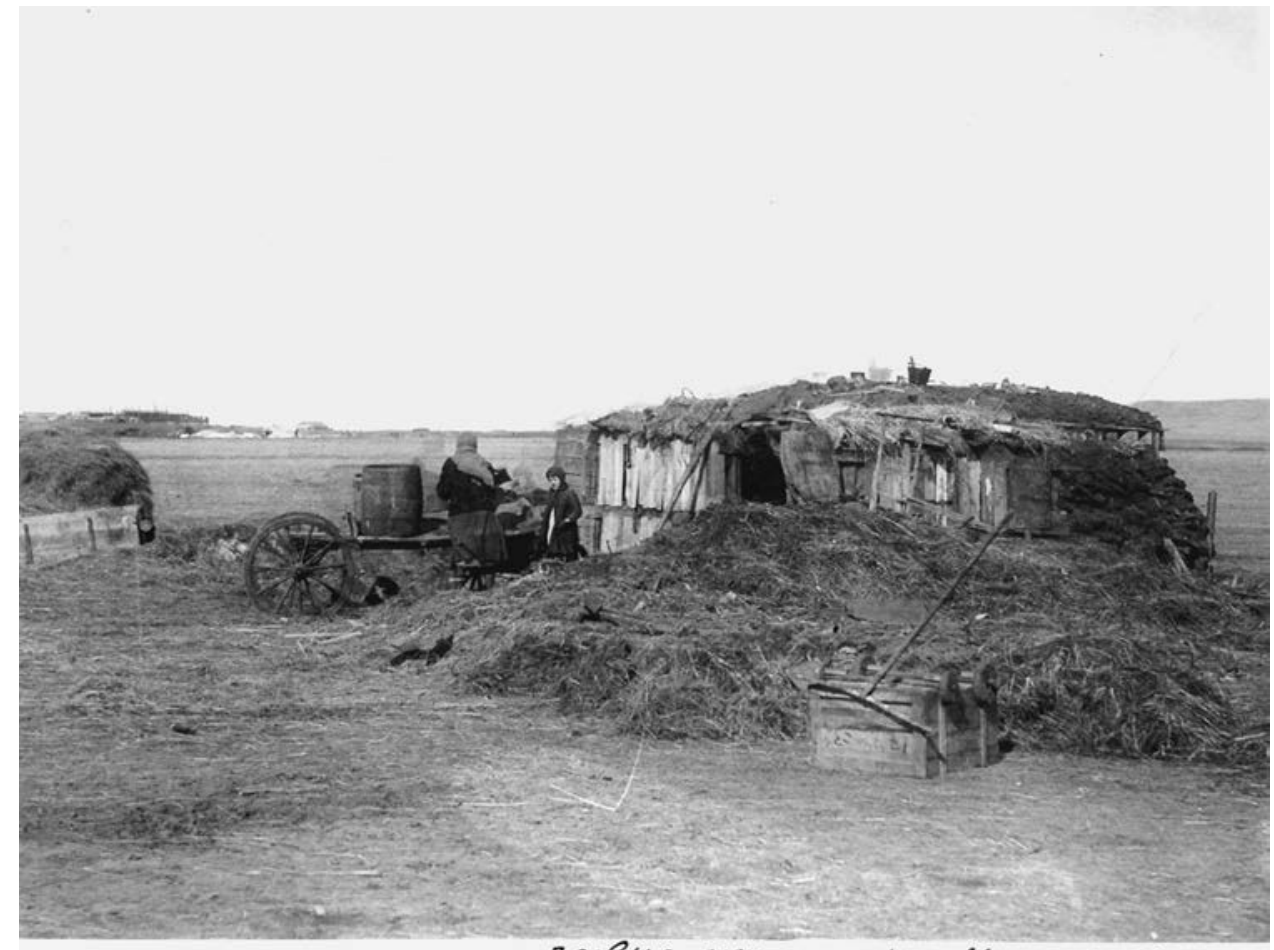

первые мемима на магнитке.

Figure 5.2. Family dugout, "first housing in Magnitka," Magnitogorsk, Russia, 1929. Magnitogorskii kraevedcheskii muzei. 


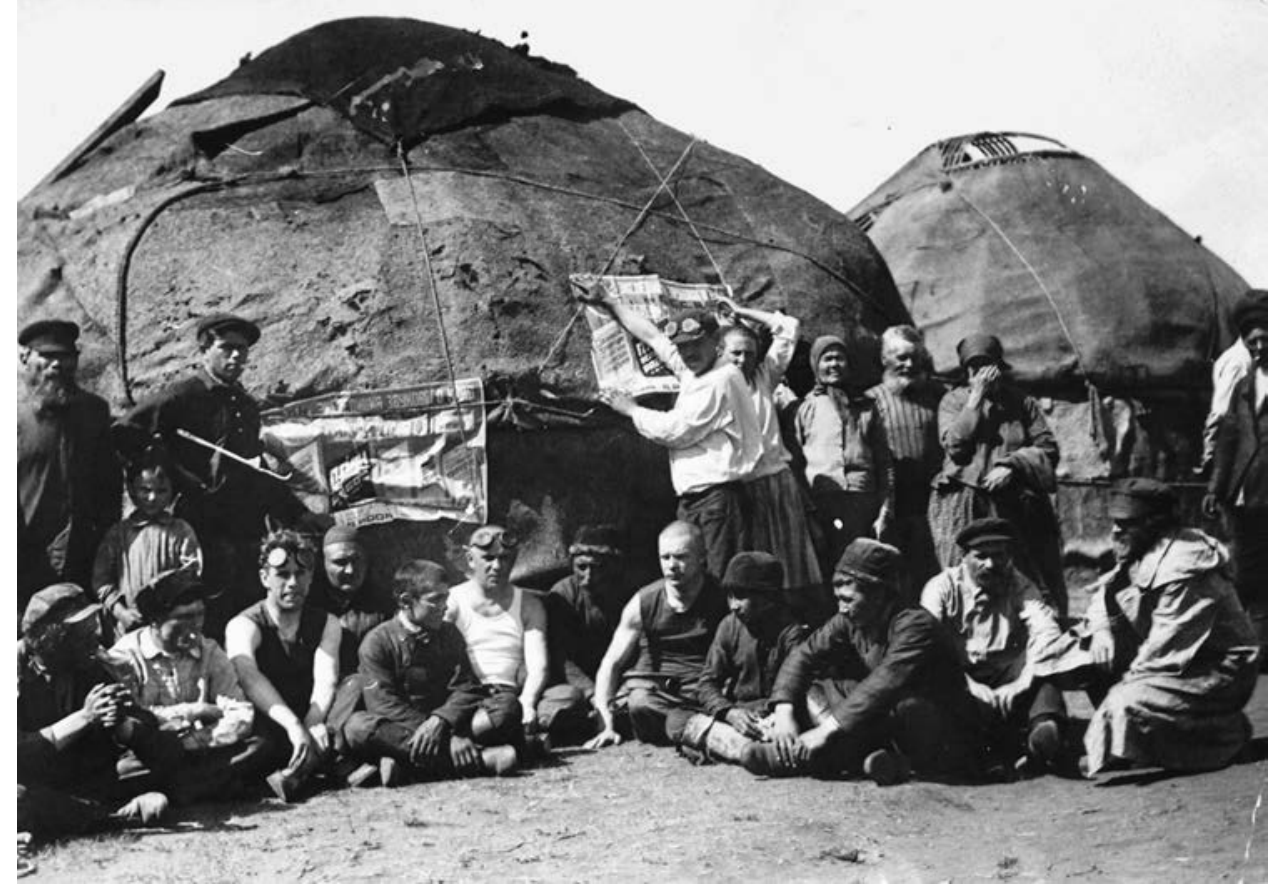

Figure 5.3. Yurt housing, Magnitogorsk, Russia, 1929. Magnitogorskii kraevedcheskii muzei.

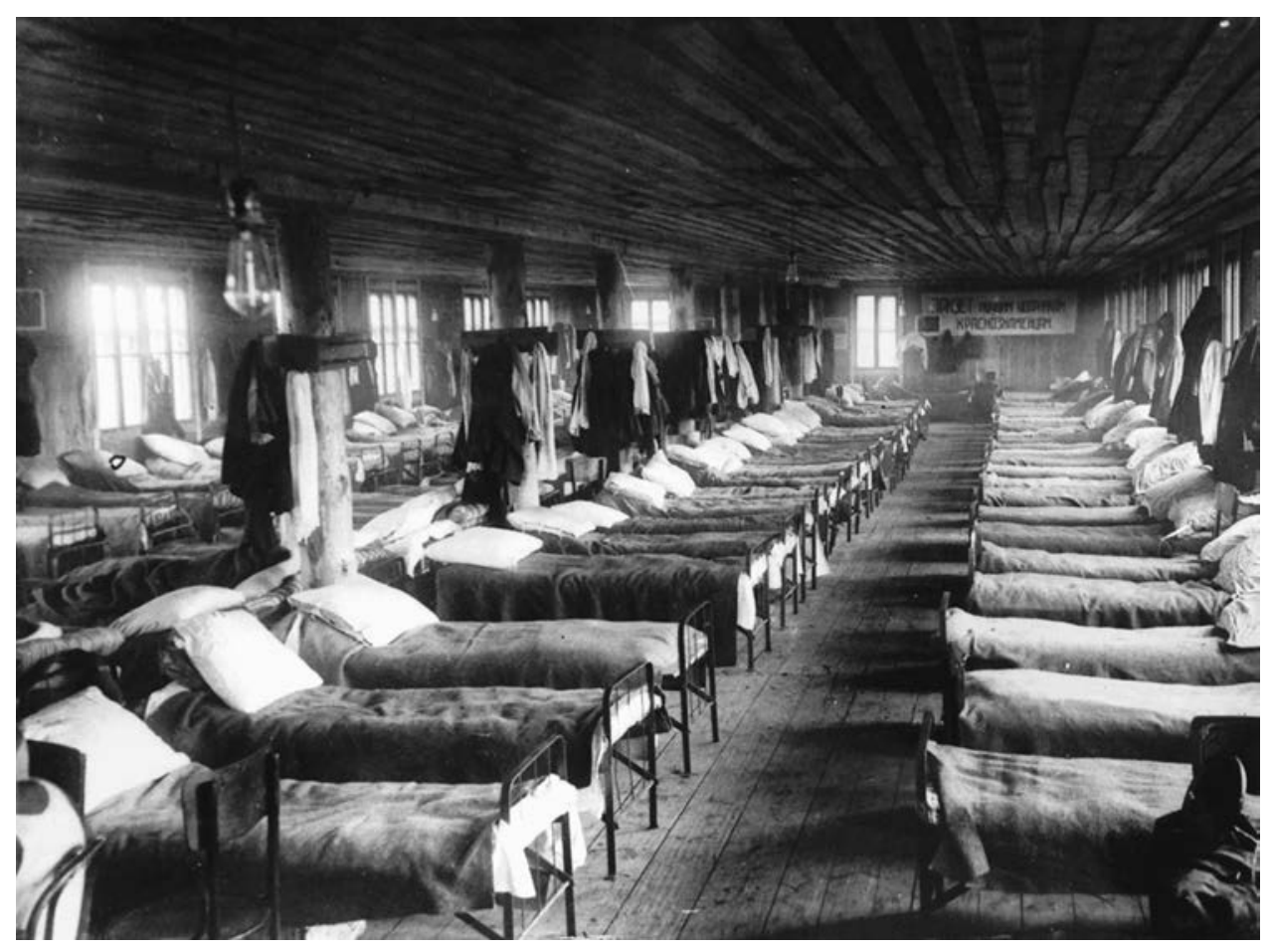

Figure 5.4. Open-plan wooden barrack housing, Magnitogorsk, Russia, 1929-30. Barracks held not only sleeping quarters but also socialist organizations, banks, the municipal government of Magnitogorsk and the Komsomol, stores, hospitals, schools, and worker clubs. Magnitogorskii kraevedcheskii muzei. 
government of Magnitogorsk and the Komsomol (the Young Communist League), stores, hospitals, schools, and worker clubs. ${ }^{9}$ So pervasive and despised was barrack life that Gugel' anticipated "there will be a city-wide celebration in Magnitogorsk on the day when the existence of a cultured city allows us to abandon these barracks. We'll burn them to the ground." 10

The designers of the industrial side of the project, the Iron and Steel Works, encountered difficulties that prefigured those faced by the designers of the socialist settlement. Neither the Leningrad nor Ural offices of Gipromez could keep up with the shifting production goals that, with each revision, changed the scale of the plant they were tasked to design. In its first 1928 iteration, the future Magnitogorsk Works was projected to produce 656,000 tons of pig iron. Over the next year and a half, the target was raised from 1.1 million, to 1.6 million, and finally 2.5 million tons by the start of 1930 , a number that amounted to a four-fold increase. ${ }^{11}$ After two years in the Soviet Union, the Freyn engineers produced a 700-page report filled with charts and graphs that was intended as a roadmap for the project. Construction drawings for the plant were notably absent. In hopes of fast-tracking construction, the Soviet government reformulated its foreign assistance contract from consultancy to concession. The Cleveland engineering firm Arthur McKee and Co. won the bid to become became both designer and part owner of the Magnitogorsk Works in March 1930 and arrived on site in early summer. Responsibility for the design of the plant was handed off to the new US engineers. The design of the city was a far more ideologically freighted endeavor, and one that would take much longer to resolve.

\section{Magnitogorsk Competition Brief as Instaurational Text}

The official brief for the All-Union Open Design Competition for the Socialist City of Magnitogorsk was crafted in Moscow by a collection of officials in November and December 1929. ${ }^{12}$ At a predraft meeting, attendees were reminded that much more than a factory was to be built out beyond the Urals- the project raised critical questions "about how to build socialist culture." ${ }^{13}$ One thing was certain: disorderly conditions on the ground in Magnitogorsk had no bearing on the design competition brief. Instead, discussants, who included Leonid Sabsovich, Vesenkha representative and chief theorist of socialist urbanism, referred to Magnitogorsk as a bare site (golyi uchastok) on which a model socialist city could be built according to prevailing urban theory. ${ }^{14}$ The text's drafters had clear direction from Sovnarkom's November 11 decree, which stated that Magnitogorsk was to be "purely proletarian" and a "significant experiment in constructing the new type of city." 15 After verbal scuffles over terminology (was it a "city" or "settlement"?), family structure (should socialist children live with their parents?), and housing typology (how tall should the buildings be?), the final version of the brief was released 
publicly at 10 am on December 22, 1929. Interested competitors had six weeks to formulate their design proposals. ${ }^{16}$

This brief is arguably the most important textual artifact from the 1929 socialist urbanism debate (figure 5.5). The stapled eight-page brochure-small enough to tuck into a book-presented the ground rules for an entirely unprecedented urban culture, one anchored by industry and predicated on new social relations. It represents a fleeting moment when visionary theorists and state officials (in some cases these were one and the same) agreed on how socialist space, and the people within it, should be organized to break all ties with capitalist models.

Françoise Choay's concept of the instaurational text helps to situate the Magnitogorsk competition brief in its time. Choay defines instaurational texts as "those writings which have the explicit aim of developing an autonomous conceptual apparatus in order to conceive and build new and unknown forms of space." Their goal, in other words, is "to provide a theoretical support and foundation for spaces, whether already built or projected." ${ }^{17}$ Choay breaks these texts into three categories: architectural treatises, utopias, and writings on urbanism. The focus here is on the first two, the treatise and utopia, which are explicit "mechanisms for generating built space." Both treatises and utopias are projective; what separates them is the degree of autonomy allowed the designer. A treatise stipulates principles and makes rules-it provides the framework for future space but leaves room for interpretation. A utopia, by contrast, is a totalized imaginary-it sets both the shape of future space and the relationships between its parts. With a treatise there is loose structure but freedom for the designer, while with utopia there is clarity but constraint.

Utopia is a concept to be summoned with caution in the context of Soviet history since Marx and Engels explicitly rejected it. Utopian socialism, the flawed precursor to their Scientific socialism, pictures clearly what the ideal future society will look like. Scientific socialism instead submits that events in the present continually shape the future. History and social progress are dynamic-and human nature is likewise negotiable-so there can be no fixed spatial model of the future (read: utopia). "We cannot outline Socialism," Lenin announced in assent with this line of reasoning in 1918. "What Socialism will look like when it takes on its final forms we do not know and cannot say." 18 The philosopher Martin Buber later found fault with this line of reasoning in Paths in Utopia. How, Buber asked incredulously, is it possible to build socialism, or anything, without a vision in the mind's eye of what shape that future might take? In asking this question, Buber put his finger directly on the quandary that Soviet planners faced at the start of the first Five-Year Plan. The lack of a clearly articulated vision of Soviet space, or rules with which to create it, resulted most often in Dzerzhinsks: haphazard, chaotic construction projects that did not align with the ideological imperatives of the socialist state. A concrete vision-call it utopia or simply a replicable modelwould have given Soviet planners "something primary and original which [was 


\section{ВСЕСОЮЗНЫЙ}

\section{ОТКРЫТЫЙ КОНКУРС}

\section{НА СОСТАВАЕНИЕ ЭСКИЗНЫХ ПРОЕКТОВ:}

А) планировки и застройки социалистического города Магнитогорска на Урале при горнозаводском комбинате;

Б) типовой жилищной коммуны

(При свободном участии в соревновании всех желающих)

НАРОДНОГОКОМИССАРИАТА ВНУТРЕННИХ ДЕ Л

МUСКВА - 1929

Figure 5.5. The All-Union Open Design Competition for Magnitogorsk, released in December 1929 by the People's Commissariat for Internal Affairs. TsDAMLM Ukrainy, f. 8, po. 1, od. zb. 431, ark. 1. 
their] destiny to build," as Buber put it. ${ }^{19}$ Defined as an instaurational text, the Magnitogorsk competition brief can be analyzed as the long-awaited concrete vision for generating Soviet built space.

The Magnitogorsk competition brief constitutes its own category of instaurational text that sits between Choay's treatise and utopia. The final approved brief is more than treatise but less than utopia; it is a suggestive but not wholly prescriptive text. Each of the published prize-winning entries shares certain characteristics like a commitment to minimal private living quarters, common public servicing, and state-run child-rearing. The competition brief defines these issues, treatise-like, as the axiomatic principles for the city's design. The remainder of the brief veers toward utopian projection, providing specific area, volume, and relational direction to the designers, from the scale of the living cell to the city. Design teams were given the liberty to invent architectural forms, but only to the extent that their solutions met the many programmatic and dimensional limits imposed by the brief. The brief that at first glance is no more than a technocratic bundle of lists yields a clear polemical program for the design of socialist settlements on close reading. An inchoate urban model is woven into the language of the competition brief, but the text remains shy of a priori form.

\section{Axioms of Socialist Urbanism}

The brief for the All-Union Open Design Competition for the Socialist City of Magnitogorsk requests designs for a newly planned industrial city on the east side of the Ural Mountains, 260 kilometers southwest of the village of Troitsk (see the appendix for the English translation of the brief). This new site, hundreds of kilometers from any significant cartographic locale, is to be planned "on the basis of a complete socialization of cultural, educational, and everyday life of all workers." 20

Competitors are asked to design two projects: a socialist city (sotsialisticheskii gorod, or sotsgorod) and a typical residential commune (tipovoi zhilishchnoi kommuny, or zhilkombinat). Both of these terms-sotsgorod and zhilkombinatemerged from the writings of Sabsovich between 1929 and 1930; it is worth clarifying the relationship between them before detailing how they were posed to the competition entrants. ${ }^{21}$ Per Sabsovich's definition, a sotsgorod is a city with a population of 50,000-60,000 that includes all programs and services needed at the municipal level. These include residential, leisure, commercial, and governmental spheres, plus the infrastructural systems to knit these together and link them to the productive sphere (the factory), on which the sotsgorod's existence is predicated. The zhilkombinat is the building block for the residential sphere only, a smaller urban unit with a population of 2,000-3,000 people. These standardized units that hold residential buildings, local schools, a workers' club, and other limited 
recreational facilities must be duplicated until the overall desired urban population of the entire city is reached. Twenty-five zhilkombinaty at 2,000 residents each is needed to reach a sotsgorod population of 50,000, for example.

The main regulations (osnovie polozheniia) for the planning and construction of the model socialist city, listed at the very front of the Magnitogorsk competition brief, can be organized into three axiomatic categories that structure the details to follow: socialist demographics, socialist novyi byt, and socialist construction. First, under the axiom of socialist demography, the brief stipulates that "all adult residents (men and women), except for the elderly, the disabled, and the sick, are involved in productive labor and of various kinds of social work." The new industrial city will be a productive city foremost, and women will be among the working population.

The next four points support the axiom of socialist novyi byt (the new everyday life). Covered by this axiom are directives related to housing type, child-rearing, meal preparation, and provisioning. Residential communes will be the only housing option provided, and complete socialization of life will rely on each worker identifying with and contributing to the communal unit to which they belong. "Aside from production work and visits to city institutions, the life of the workers is concentrated in the housing commune and its environment, liberating the working people from the worries of maintaining individual property, and permitting active participation of the working people in the collective economy and byt of their commune," the brief stipulates. With the full instantiation of the novyi byt, women are liberated from household tasks, most important childcare and cooking. In Magnitogorsk, children under sixteen years of age (the age of able-bodied productivity) will live "under socialized care and in closed nurseries, kindergartens, and boarding schools located near the adult dwellings, not isolated in children's and school campuses" (this last note may have been a minor concession to Nadezhda Krupskaia, Lenin's widow, who vigorously disapproved of separating children from their parents). The degree to which fully socialized parents will be involved in the lives of their offspring is ambiguous in the Magnitogorsk brief. Children will be physically proximate-in institutions located near adult living quarters-but space for children is not to be provided in the living quarters of married couples. Freedom from cooking is ensured by the fact that "meal preparation for the entire population of the city is carried out by a centralized food processing plants that deliver all types of food to each manufacturing facility, public agency, and residential commune." Cooking will occur in factory-kitchens and bakeries, and all meals will be consumed in canteens. Lastly under this axiom, "supplies for the entire population-items of general and individual consumption-will be handled by a department store and a commodity supply network organized by the residential communes." 22 Unlike during the NEP, when small businesses supplied consumer goods that the state was unable to provide, the new socialist city will be entirely free of private enterprise. 
Finally, there is the axiom of socialist construction, which covers guidelines for conveyance, construction organization, land regime, and general building orientation. Busses and automobiles will provide transportation for workers to "more remote manufacturing locations and institutions" and on "countryside excursions." This provision implies that residential communes will be located close enough to the production zone that laborers can walk to work. The residential communes will be constructed by the state as housing cooperatives, and no land will be provided to individual builders. All premises will be "oriented with regard to the most favorable sunlight conditions.” This rather specific environmental directive may have arisen from ongoing mass housing research and construction in Germany, undoubtedly known to the Magnitogorsk competition brief drafters. While no specific solar angle is prescribed in the Magnitogorsk brief, awareness of heliotropism is expected in submitted designs.

The regulations stipulated in these three axiomatic categories set the basic parameters for competition submissions. The following two sections of the brief provide detailed information for the separate (though interrelated) design projects required of competition entries: the socialist city and the typical residential commune. Both projects are described through program elements, dimensional attributes, and in certain cases relationships between building and site. These are the strict rules of operation that give urban and architectural shape to the general principles presented in the brief's opening paragraphs.

\section{Socialist City of Magnitogorsk}

The competition brief stipulates that the socialist city of Magnitogorsk will be built and sustained by proletarian labor. Details for designers begin, therefore, with specific demographic targets. The entire population of the socialist city at full development of the metallurgic plant, silicate factories, and mines will be 50,000 residents, a number to consist of 68 percent able-bodied adults, 24 percent children younger than sixteen, and 8 percent elderly and disabled. These residents will become socialist citizens through programmatic and spatial conditions designed to install the novyi byt. Workers will enjoy communal living and servicing; cultural, educational, and recreational opportunities; and state-provided health care. Cultural life will be centered on the Palace of Labor and Culture with its library reading room, meeting rooms for trade unions and health education, and separate theater and cinema buildings. The primary recreational site for the city will be the Park of Culture and Leisure with a stadium, playing fields, and sporting clubs. A network of public squares and boulevards will offer passive leisure, and municipal greenhouses will furnish the planted matter.

The residential educational institutions required in the brief cover three stages of young life. The youngest citizens, up to age eight, will be taken care of in 
kindergartens and specialized daycare facilities for disabled children. Students up to working age, from eight to sixteen, will be accommodated in large schools with a maximum population of 800 . These schools will have grounds large enough for planting crops and raising animals as part of the standard curriculum. In Socialist Cities, his 1930 book, Sabsovich argued that there would be blanket cost reductions for agricultural food products "due to the fact that farms can employ children as a necessary element of their upbringing and education, as well as the elderly and the feeble, who are not useful in other productive labor." ${ }^{23}$ Juvenile and elderly gardening and animal husbandry in service of communal food provision would wrest productivity out of the least able-bodied members of the population. For working age youth over the age of sixteen, the brief requires inclusion of a higher technical school (vyshee tekhnicheskoe uchebnoe zavedenie or VTUZ) with metallurgical, chemical, and mining departments, on a site near the factory grounds.

The communal services specified in the competition brief are broken down into food provision and sites of everyday civic life. The city of Magnitogorsk will be catered by a centralized food processing plant to prepare hot meals and baked goods. The plant, located next to a rail line, will have specialized sausage, cheese, confectionery, and beverage production facilities to feed 30,000 people in its first phase, with expansion possibilities for an additional 20,000 in the near future. Critical but ancillary food production programs include a slaughterhouse, industrial refrigerators and food warehouses, and a disposal plant. Sites of everyday civic life include venues for shopping (a department store); communications (mail, telegraph, telephone, and radio); laundry; bathing (bathhouse and pool); and a number of technical services like a garage, fire station, repair shops, an incineration plant, and crematorium. Finally, the health of city residents will be overseen in a 400-bed hospital and a central health clinic with two regional branches: one convenient to the industrial complex, the other to the residential area. The description of the wellness program in the competition brief is exhaustive. It details myriad hospital departments-from maternity to morgue - as well as separate isolation units, laboratories, birth homes, and other specialties.

The items that elucidate the particulars of socialist construction in Magnitogorsk give specific temporal, topographic, and relational direction to the competition entrants. Most important in the context of the first Five-Year Plan is the schedule. City construction is to be phased over the first two Five-Year Plans30,000 residents will be accommodated by the end of the first, and the additional 20,000 by the end of the second. The demographic limit set on Magnitogorsk is not a hard one, however, for the brief stipulates that "the city should be planned to accommodate further expansion in future, after the first two five-year plans." The indication toward expansion-although buried among requirements and other data points-sets the competition brief in conflict with Sabsovich's texts. In Socialist Cities, Sabsovich unequivocally supported hard population caps for future urban centers. "We must consider that in a socialist city, public life and the collective 
private life of the population will be developed on an immeasurably large scale, larger than the space available in our cities. Therefore, it is advised that the socialist city should be built to accommodate a population of no more than 50,000-60,000 people." ${ }^{24}$ Sabsovich's argument in favor of fixed demographics hinged on the inextricable interdependencies of full socialization. Production, housing, education, and communal servicing are suspended together in a delicate web. Unexpected inputs or outputs from any of these constituent elements threaten to destroy the communal balance, so the population of a socialist city must be planned for, reached, and frozen. This was exactly the argument that Ivanitskii used against the fixed-population model in discussions with his Baku clients in January 1930 when he cited the industrial city of Zaporizhzhia as his example of why population caps do not work in practice. If the 300,000-person city were planned as a collection of so-called socialist cities, each with a maximum population of 50,000, urban territory and urban life would be artificially fragmented. Redundant roads, utilities, and institutions built for each of these urban units would place an undue fiscal and managerial burden on the greater municipal government. ${ }^{25}$ The Magnitogorsk brief satisfies each position, albeit obliquely. The 50,000-person population target matches Sabsovich's model, but the door is left open for organic urban growth beyond that target, per Ivanitskii's suggestion.

Additional pragmatic planning details also fall under the axiom of socialist construction. Magnitogorsk will be serviced by the "most modern scientific municipal improvements including district heating, water supply, sewage, electrification, and gasification provided by the combined factory installations," the brief stipulates. Taking a lesson from the Dzerzhinsk fiasco, where the city was built downstream of industrial outflow, the Magnitogorsk brief states the precise source of the city's water supply-groundwater aquifers on the Ural floodplain-and the downriver location of sewerage outfall. The "open steppe nature of the city" requires softening, the brief notes in the conclusion of this section. Tree planting, especially in the zone between the factory and residential areas will be necessary. Lastly, the entrants are asked to pay particular attention to the topographic conditions of the site, the location of the production area (already under construction), and the existing rail lines when designing the street network. All of these items and their locations were included on a 1/5000 site plan attached to the brief that has since been lost.

\section{Typical Residential Commune or Zhilkombinat}

The competition brief next turns to instructions for the design of the typical residential commune, or zhilkombinat. Here, the socialist demographics of the communal sub-unit are further refined. Each residential commune, a complex of buildings, will be designed for a capacity of 1,500-3,000 people of all ages who will occupy 
their own respective sectors. Issues related to socialist construction principles are straightforward. Buildings within the residential commune are allowed to be no more than four stories. ${ }^{26}$ The ceiling height of residential spaces will be 2.8 meters (just over 9 feet), and the common areas from 2.8 to 4 meters. The exception to this rule is a large theater space with a minimum 4-meter ceiling height. The limits placed on building and floor height, while seemingly benign, greatly impact the architectonic language of the entries. Not all design teams abided by this rule. The OSA team led by Ivan Leonidov, whose Magnitogorsk competition entry is best known in the West, baldly disregarded the height restriction with slim residential skyscrapers distributed in a diffuse checkerboard pattern.

The balance of the residential commune section of the brief provides details to ensure installation of the novyi byt. The axiomatic principles of the model socialist city, noted at the front of the brief, gesture toward social reconfiguration, but the radical and controversial aspects of the new socialist life become clear here. First and foremost, the nuclear family is entirely liquidated, a process envisioned by Soviet feminist Aleksandra Kollontai nearly a decade before. To enact this process, the population of every Magnitogorsk zhilkombinat is divided into four age groups-babies (0-4), kindergarteners (4-8), school-aged children (8-16), and adults $(16+)$ - each of whom will live in a specially designed sector of the commune. The separation and atomization of each citizen will permit, perhaps paradoxically, a more robust collective sphere, or so argued Sabsovich:

In the socialist city, houses should be constructed in such a way that they provide the greatest convenience for the worker's collective life, collective work, and collective recreation. They should also provide the most comfortable possible conditions for individual work and individual leisure. These houses should not have separate apartments with kitchens, pantries, etc. for individual domestic use since all of the worker's everyday needs will be completely socialized. In addition, they should not include space for private family life, because the idea of family, as we now know it, will no longer exist. In place of the closed, isolated family unit we will have the "collective family" of workers, in which isolation will have no place. ${ }^{27}$

In this prescription for socialist housing outlined in Socialist Cities, Sabsovich summarily eradicated the spaces in which the middle relational scale of the nuclear family might flourish, such as the kitchen table or sitting area within the apartment. All socializing and recreating would occur in "social condensing" spaces like canteens and worker clubs. Either the worker would engage in solo work and leisure in her single room, or she would immerse herself in the collective.

The Magnitogorsk brief assumes nearly all of Sabsovich's recommendations. Competition entrants are instructed that sleeping accommodation for adults can be designed for singles or for two to three people (the unit mix is unspecified). The 
sleeping rooms - for that is what these spaces are exclusively for-will be designed at 9 square meters per person for a single, 7.5 square meters per person for all other types. To make such tight quarters feasible, the brief specifies that all furniture within the sleeping quarters will be collapsible: folding beds, sofas, cupboards, and so on. The social condensing spaces, on the other hand, will be ample: 2-3 square meters per adult will be allocated to these programs located either in the residential buildings or in separate buildings connected by heated passageways. ${ }^{28}$ Designers must provide space to accommodate two scales of communal interaction for the residents. At the local level, each group of sleeping rooms is to be provided a pantry with a gas stove for heating food, a social room for greeting guests, a bathroom, showers, a washroom, toilet, laundry basin, and a common balcony. At the commune level, residents will share dining, laundry, and club facilities; and a commercial area replete with a hair salon, a solarium, and sports playing fields. Limits to full communality are set by population volume: the dining room should hold at maximum 25 percent of the adult population of the zhilkombinat, and the club 20-30 percent. Nonetheless, just a quarter of the adult population eating in the canteen at the same time would tally 570 people, a large enough crowd to engender a sense of community. ${ }^{29}$

And where are the children-the future socialist individuals-in this new arrangement? Without exception, they live separately from the people who spawned them. "The question of joint dwelling for children and their parents can only be answered in the negative," stressed Sabsovich. "Infants are best located in special buildings where the mothers can visit for feeding . . . Preschool and schoolage children should spend most of their time in spaces designed for their learning, productive work, and leisure. It is clearly pointless to provide space for them in the same dwelling as their parents, where they would return at night. Therefore, house-communes should only be built for adults." ${ }^{30}$ In the Magnitogorsk competition brief, adults and children are duly separated. Children are allocated learning and living sectors by developmental stage and are to be accommodated in state-run dormitories: nurseries for children up to age four and kindergartens for four- to eight-year-olds. Competition entrants are asked to provide adjacent play yards for the children, and otherwise should refer to requirements set by the People's Commissariats of Health and Education for dimensional and relational criteria related to these programs. Older children will live in boarding schools (internaty), in which the structure of everyday life mimics that of the adult sector. The brief stipulates that each dormitory room will accommodate sleeping groups of up to ten children. As with the adults, social condensing spaces will be provided for the children at the local and community scale. Toilets, showers, a linen closet, and washing up sink are shared by sleeping group. Common areas for the whole school include a dining room to accommodate half of the children; classrooms; a library and reading room; a red corner; and a large room for entertainment and sport. The schools for all ages must be connected to the rest of the commune by heated passageways. 
The residential commune as described in the Magnitogorsk competition brief was controversial in its time on relational and temporal terms. Controversy number one surrounded the proposition that familial relations be dissolved in toto. The residential commune was to be the solvent, breaking apart deep interpersonal relations between partners and between parents and children. Sabsovich conceded that "some of these rooms (or maybe all) must have a door or sliding partition to connect to adjoining rooms through interior circulation, if the husband and wife wish." Yet he stressed that "there should be no joint living space for husbands and wives." 31 The conjugal door might satisfy immediate sexual desires, but emotional attachment between spouses was a need left unaddressed. As for state-run child-rearing, Krupskaia was not the only Soviet thought leader to question the utility of breaking filial ties. Nikolai Miliutin proposed a more measured approach to socialist child-rearing in the transitional period in his book Sotsgorod (1930), suggesting that "in building special institutions for the life and education of children (closely connected with the adults' home) we are establishing only the necessary conditions so that parents, when they wish, may send their children to these institutions . . . This will not, however, mean compulsion." ${ }^{32}$ Krupskaia, for her part, stressed that cross-generational interaction was of benefit to both children and adults, and not just in the transitional period. "When people talk about kids, they often seem to be thinking of them as disorganized, hooligan-like interferers," she wrote. "But the new socialist house should be organized so that kids can grow in it, develop, learn from adults how to organize themselves, without annoying or disturbing anyone. And, of course, when building, you cannot economize on every centimeter. It is necessary to sew the housing clothes for [cultural] growth, anticipating the development of the inner life of the house, its social life." ${ }^{33}$ Because she advocated for cultural growth, Krupskaia was lumped with the so-called gradualists, who understood the transition from old to new ways of living under socialism as a process that would likely take some time.

Another controversy had to do with tempo. In November 1929, the Gosplan Presidium member N. A. Paskutskii noted that "we are living in a transitional period," and he stressed that the rapid tempo of socialist construction would, in itself, bring about sharp changes in the lives of the working class and laboring peasants. ${ }^{34}$ Intensifying this seismic cultural shift by forcing radical domestic changes too quickly was unwise, Paskutskii argued. The Magnitogorsk brief takes no such equivocal stance: the proposed residential commune was expected to immediately and totally instantiate the new way of life. According to antigradualist Sabsovich, that was its primary asset. To make his argument in favor of the residential commune, Sabsovich first denounced the retrograde Chernyshev version of the Magnitogorsk city plan:

The invention of any kind of "transitional forms" (perekhodnye formy) of dwelling is simply unjustifiable opportunism. The original plans of the new 
socialist city Magnitogorsk, for example, called for the design of dormitory style rooms for four people; it also called for family rooms for a husband, wife, and two children ... The authors of these projects cite the backwardness of the workers, who apparently are unprepared for the abrupt transition to the novyi byt. These authors are advised first to get rid of their own backwardness and prejudices before they assign them to the workers. ${ }^{35}$

In Sabsovich's opinion, there was no benefit to proposing half solutions in deference to the transitional state. He hung his argument on the workers themselves, for whom he purported to speak. The workers were ready for radical change, he asserted-it was the socialist intelligentsia who could not imagine, and were discomfited by, the idea of full communalization. The first Five-Year Plan was the opportunity to overthrow the past and build the future in the here and now, claimed Sabsovich. The Magnitogorsk brief shares this prospective lean forward.

The remainder of the Magnitogorsk brief lays out the substantive submission requirements. The sheer volume of material expected of entrants communicates that this is much more than an "ideas" competition. Design teams are asked to provide a general plan of the city to indicate residential, public, and administrative structures; their parcels; various types of green spaces; and the schematic locations of water and sewer mains. Typical street cross sections are also required. Detailed drawings of the residential commune must include plans at various scales; sections with structural systems; elevations; and axonometric and perspective views. An explanatory text must provide basic information about the scheme and is to be accompanied by a detailed cost estimate (inclusive of the formulas used to generate the results). Additional tables must calculate the area and volume assigned to each program and the percentage of the residential commune allocated to each age group by area and volume. This is an enormous amount of information to generate in six weeks.

\section{Visions of Concentrated Collectivism}

The deadline for receipt of competition entries at Magnitostroi's Moscow office was February 2, 1930. Entries were to be submitted under a verbal or graphic slogan (pod devizom), to obscure authorship and ensure judging fairness. In addition to the seventeen open entries received, the competition organizers invited five well-known design teams to submit proposals: MAO, OSA, Kartoizdatel'stva NKVD (the cartographic office of the People's Commissariat for Internal Affairs), the Stroikom working group, and a team led by Sergei Chernyshev, the project's previous architect. ${ }^{36}$ In total, the jury deliberated over twenty-two schemes for the socialist city of Magnitogorsk and residential commune to select four prizewinning designs that would, as a consequence of their success, become the property of Magnitostroi. 
The jury was composed of a variety of experts in urban planning matters. Former Commissar for Education, Anatolii Lunacharskii, chaired the jury and was assisted by vice chair, Nikolai Miliutin. Among the specialists who adjudicated the competition were local administrators from Magnitostroi and the Ural regional government; representatives from the People's Commissariats for Internal Affairs, Education, and Health; the Construction Committee of the Russian Republic; the Women's Department of the Central Committee; the All-Union Central Soviet of Trade Unions; the Central Committee of the Young Communist League; and Moscow architects Viktor Vesnin, Ivan Mashkov, and Andrei Ivanov. ${ }^{37}$

In their detailed report, the jury divided entries into two categories: "concentrated city planning" (kontsentrirovannaia planirovka goroda) and "linear city planning" (lineinaia planirovka goroda). The formal divergences between the two submission types can be explained by the sociospatial theories that drove them. Entries from the concentrated group hewed to the urbanist writings of Sabsovich, while those from the linear group followed Okhitovich's disurbanist theories. Notable concentrated city entries came from MAO, Kartoizdatel'stva NKVD, and Chernyshev, as well as the prize-winning anonymous teams Black Square, Roman Numeral Five, Two Lines, and Three Lines. Because the competition brief requested a city plan stocked with dense 3,000-person residential communes on Sabsovich's insistence, the prevalence of concentrated city entries is not surprising. The disurbanist schemes submitted by OSA and Stroikom (a team also made up of OSA members) were the sole members of the "linear city" group whose designers disregarded the call for dense residential communes. ${ }^{38}$

As the jury's grouping implies, the concentrated planning schemes share significant formal and organizational characteristics, chief among them embrace of controlled density. On the whole, these entries are cognizant and respectful of the difficult existing conditions on the site. Each of the concentrated city submissions places the future city to the southeast of the intersection of factory, lake, and dam, and between Magnetic Mountain and another hill to the south (figure 5.6). Site planning geometries for the concentrated city designs are generated by connecting the factory gates with the open southeasterly swath of land, and all entries provide a green buffer between the factory and the residential sector of the city. In nearly every case, a single residential commune type is repeated in a regular grid pattern, with strips of green space acting as expansion joints between quadrants. Long midrise housing bars run north-south, almost to an entry. This orientation allows for optimal east-west insolation on the broad sides of the residential buildings.

The site plan of the co-second-place-winning Black Square team entry, a representative concentrated city example, indicates the factory and its snarl of rail lines lightly penciled in at the bottom (west) of the drawing (figure 5.7). The factory gates open onto a green buffer zone that offers access to an administrative center to the left and a cultural/recreational center to the right, while straight ahead stretches a three-kilometer axis lined with identical residential communes. An axonometric 


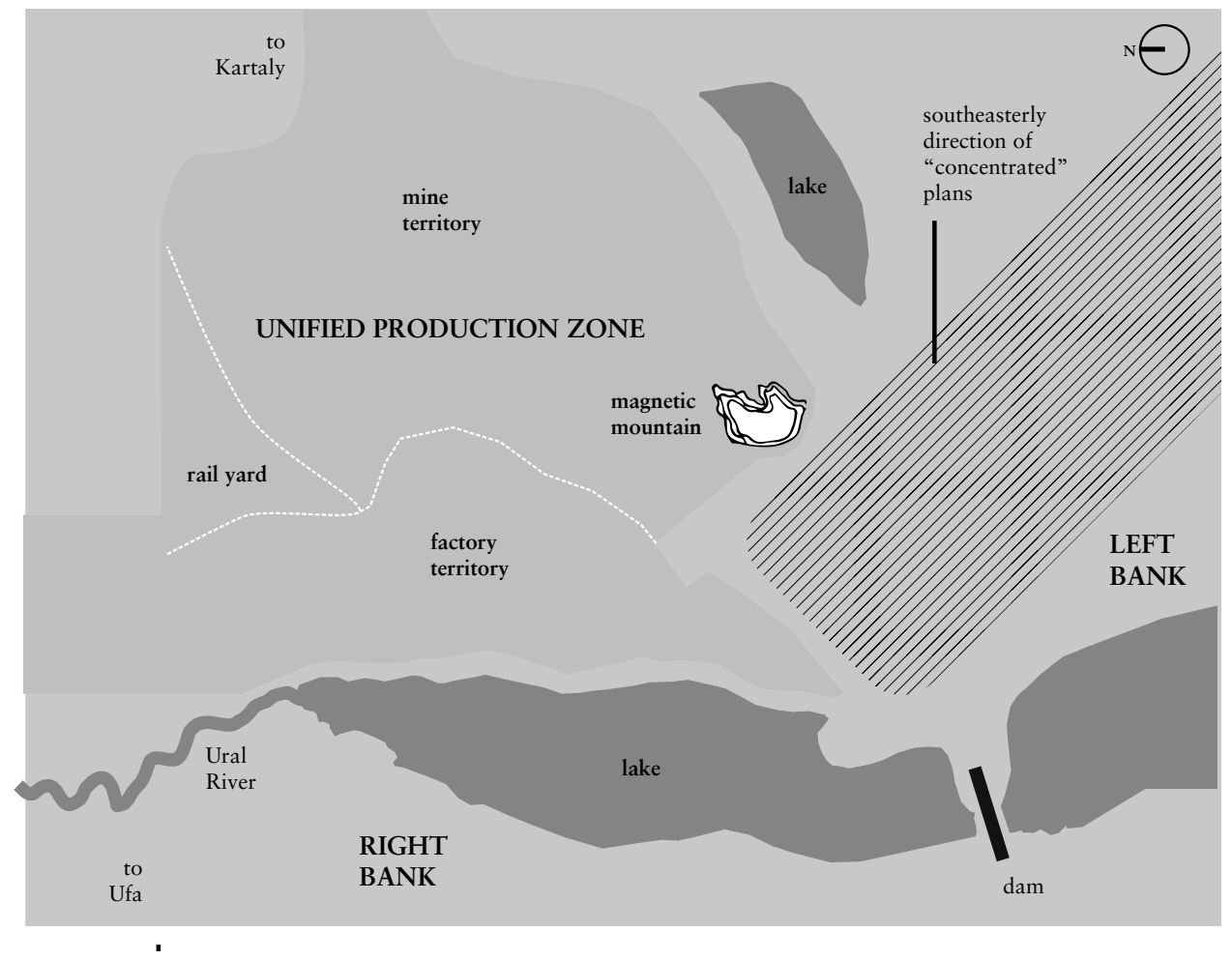

Figure 5.6. Siting key to the All-Union Open Design Competition for Magnitogorsk design entries, 1930. Map by the author, adapted from Sovetskaia arkhitektura, no. 3 (1933): 29.

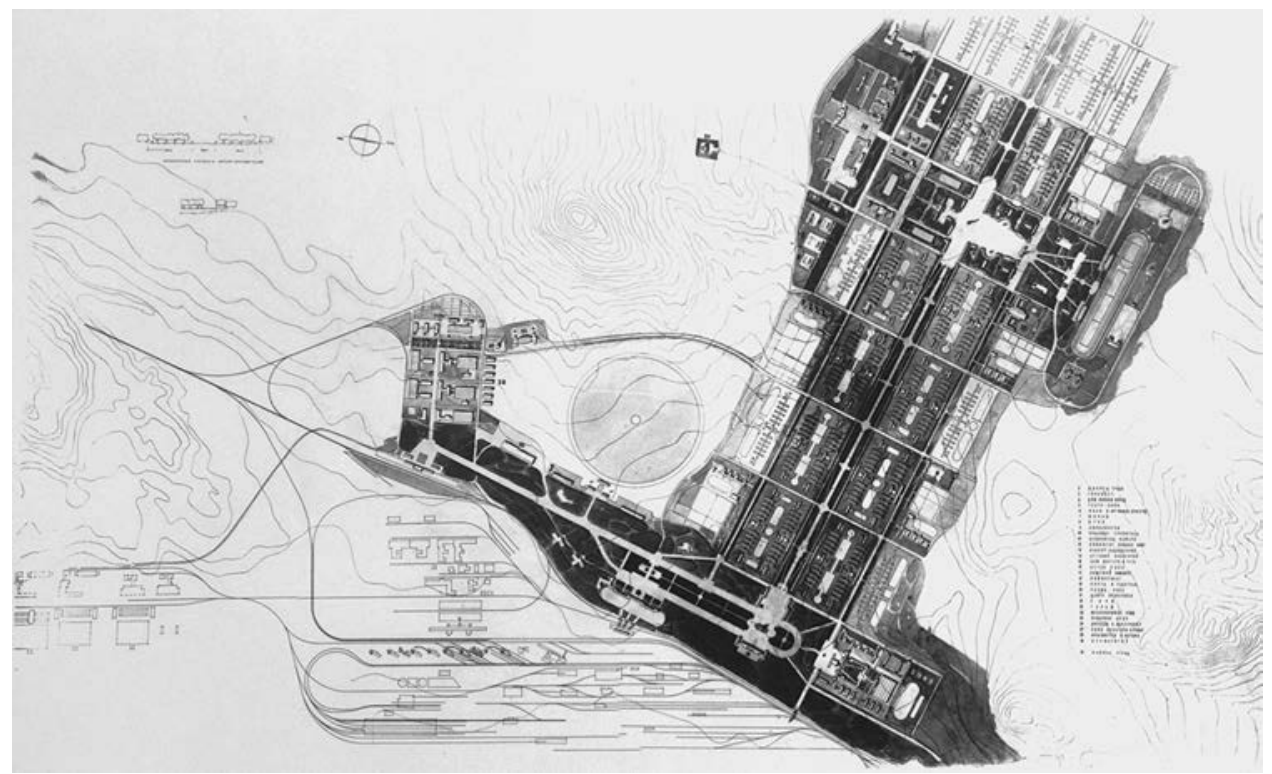

Figure 5.7. Black Square team sotsgorod plan, All-Union Open Design Competition for Magnitogorsk, 1930. 2nd prize (tie). Designers: F. B. Bialostotskaia, Z. Rozenfel'd, and B. Rozenfel'd. TsDAMLM Ukrainy, f. 8 , po. 1 , od. zb. 431 , ark. 61 . 
drawing of the typical residential commune shows a bilaterally symmetrical design (figure 5.8). The long southeasterly park axis-one mirror line-runs through the middle of the scheme. Each of the two residential clusters stretched along the sides of the green spine is entered through a central communal building that marks the second mirroring axis. From the communal entry, residents move right or left through heated passageways to five five-story residential blocks oriented perpendicular to the communicating corridor. At the end of the sequence sits an educational building that once again faces the linear park. Detailed plans and sections explain the complex circulation of the typical residential building (figure 5.9). On the ground floor, a regular grid of slim columns holds most of the building off the ground to allow for open air passage beneath and between the residential bars. A large common stair in the main entryway brings residents up to a single-loaded corridor on the first residential floor. Pairs of shallow single-exposure sleeping cells at 8 and 9 square meters each-one room per worker, with a shared bathroom for

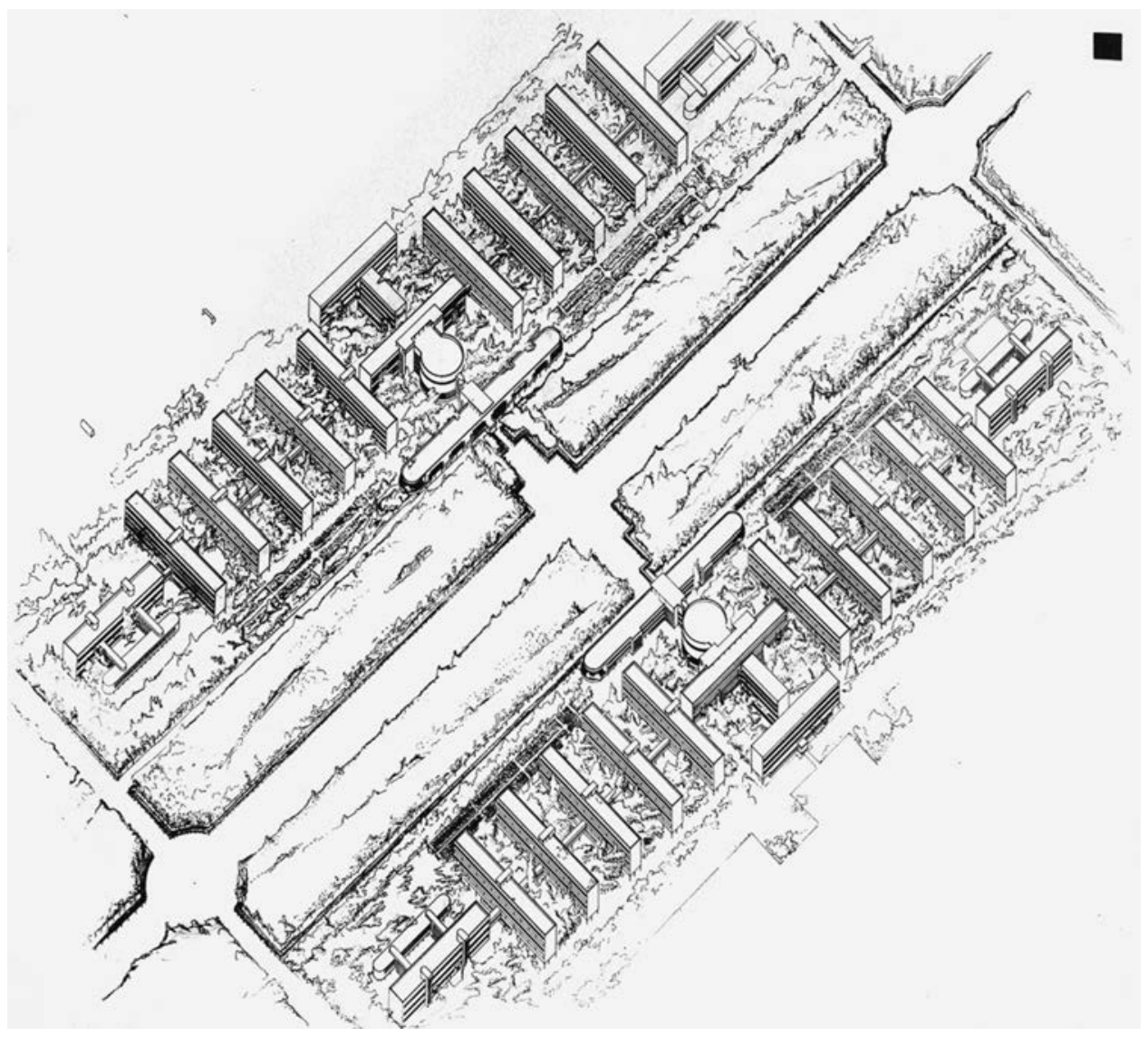

Figure 5.8. Black Square team zhilkombinat axonometric projection, All-Union Open Design Competition for Magnitogorsk, 1930. 2nd prize (tie). Designers: F. B. Bialostotskaia, Z. Rozenfel'd, and B. Rozenfel'd. TsDAMLM Ukrainy, f. 8, po. 1, od. zb. 431, ark. 68. 

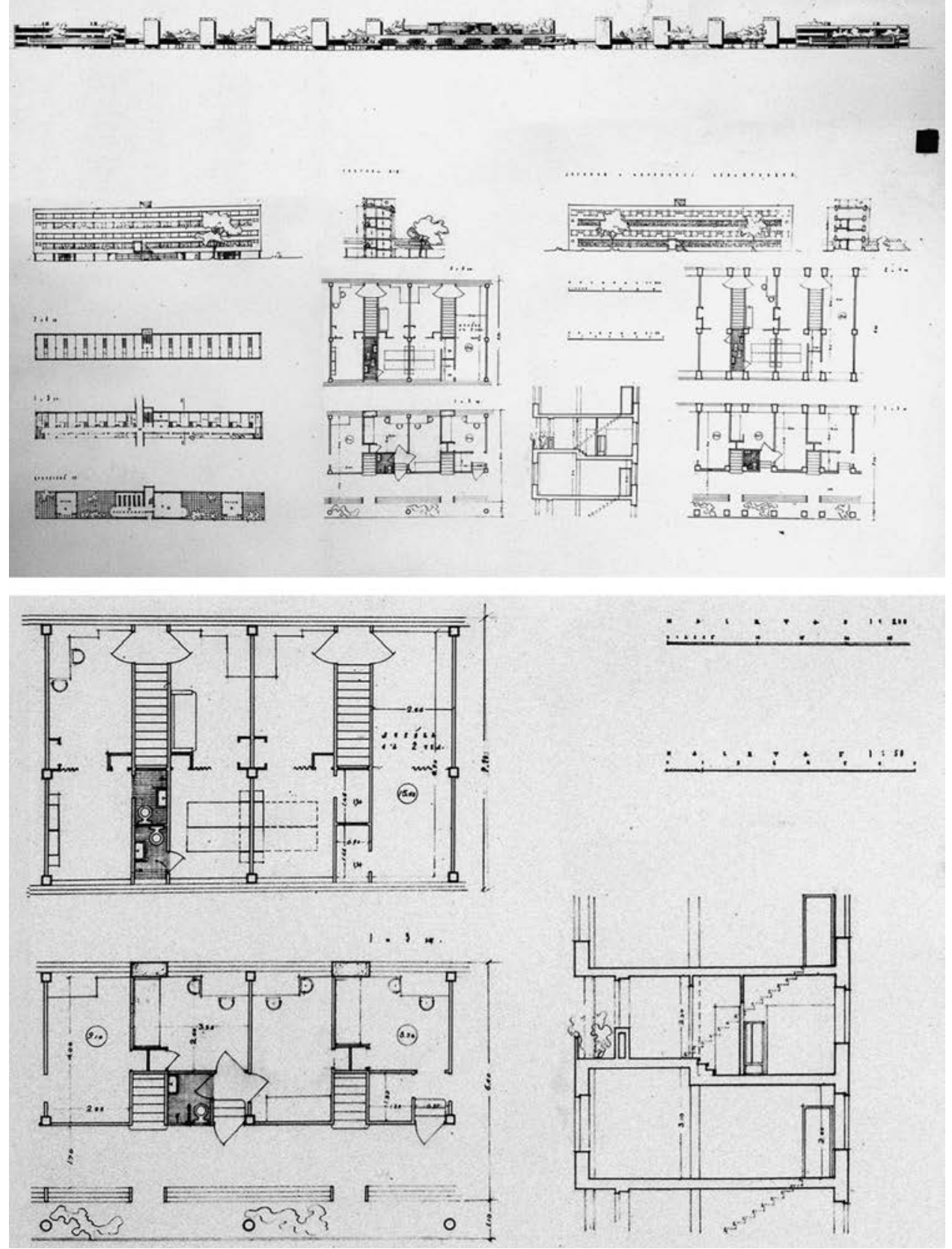

Figure 5.9. Black Square Team zhilkombinat elevation (top), residential building plans and sections (middle), and detail of paired skip-stop floors (bottom), All-Union Open Design Competition for Magnitogorsk, 1930. 2nd prize (tie). Designers: F. B. Bialostotskaia, Z. Rozenfel'd, and B. Rozenfel'd. TsDAMLM Ukrainy, f. 8, po. 1, od. zb. 431, ark. 52, 55.

the pair-are directly accessed from this second story hallway, as are narrow stairways that climb up to the second residential floor. Long double-exposure units on the second floor, each with its own toilet room, accommodate two people each in 
15 square meters. There are no private kitchens in any of the units. The sequence repeats on the third and fourth residential floors. The clever circulation design, with a common corridor only every other floor, is a variation of the so-called skip-stop section that would have been well known to jury vice chair Miliutin who was by this time living in the penthouse of the skip-stop Narkomfin Building in Moscow, designed by his friend, Moisei Ginzburg.

The competition brief is richest in instruction for the residential commune, or zhilkombinat, and it is at this scale that the concentrated entries are most inventive. The axonometric drawing of the Three Lines team zhilkombinat, for instance, is detailed enough that it invites the viewer to inhabit the complex (figure 5.10). Residential, communal, and educational buildings, arranged in a dynamic zipper pattern, surround a park with a running track. Open spaces of various sizes, surfaces, and degrees of privacy nestle between the interlocked buildings. In the drawing, the edges of the complex bleed into planted open spaces on the east and west, while another identical residential commune sneaks into the frame at the southern edge to suggest a regular repeating pattern that is borne out on the large site plan (figure 5.11). Other site plans among this group, like that submitted by the Roman Numeral Five team, share similar organizational principles and aesthetics (figure 5.12). The Roman Numeral Five zhilkombinat is composed of thin,

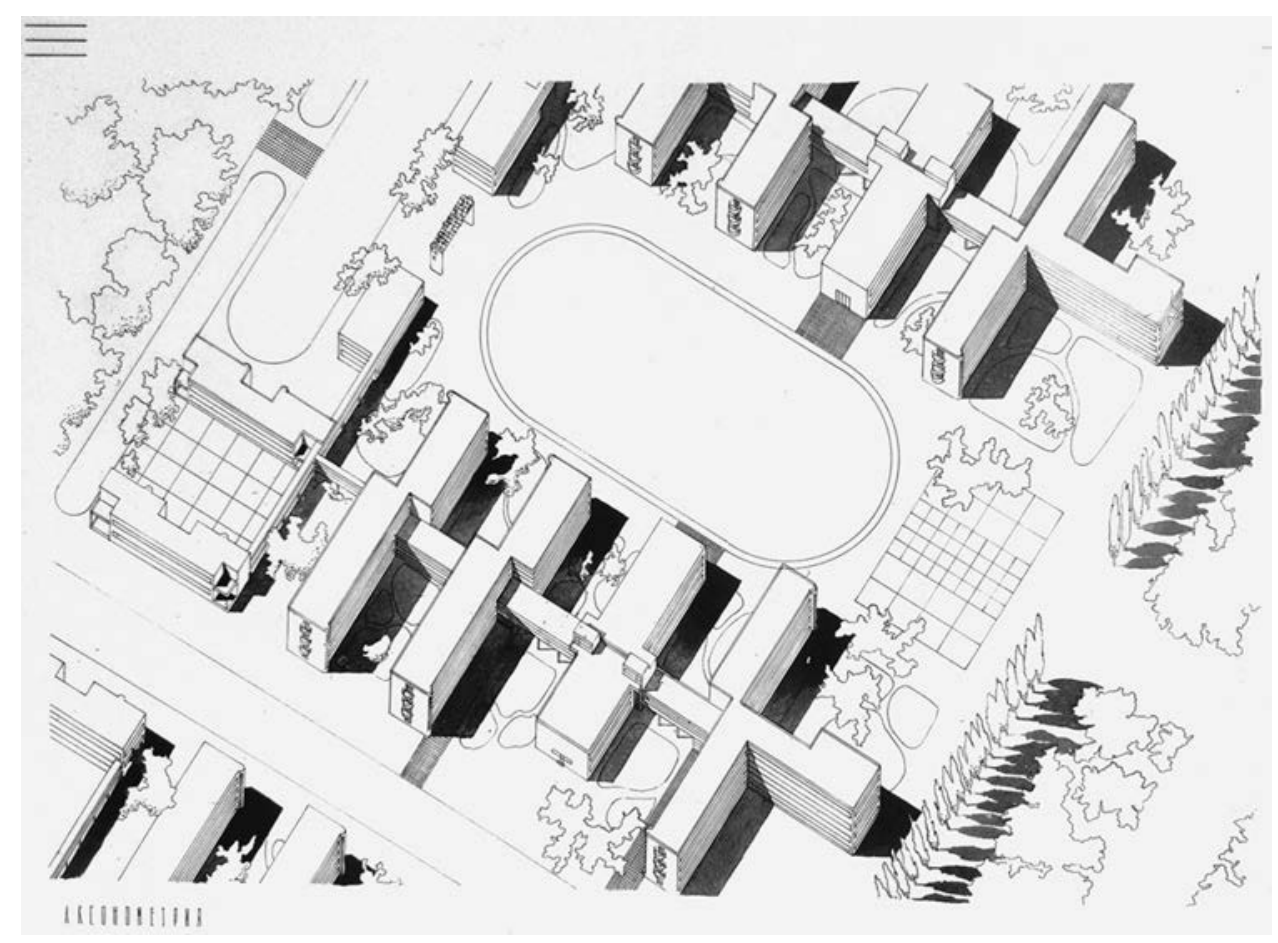

Figure 5.10. Three Lines Team zhilkombinat axonometric projection, All-Union Open Design Competition for Magnitogorsk, 1930. 3rd prize. Designers: R. Val'denberg, S. Leontovich, and D. Meerson. TsDAMLM Ukrainy, f. 8 , po. 1 , od. zb. 431 , ark. 67. 


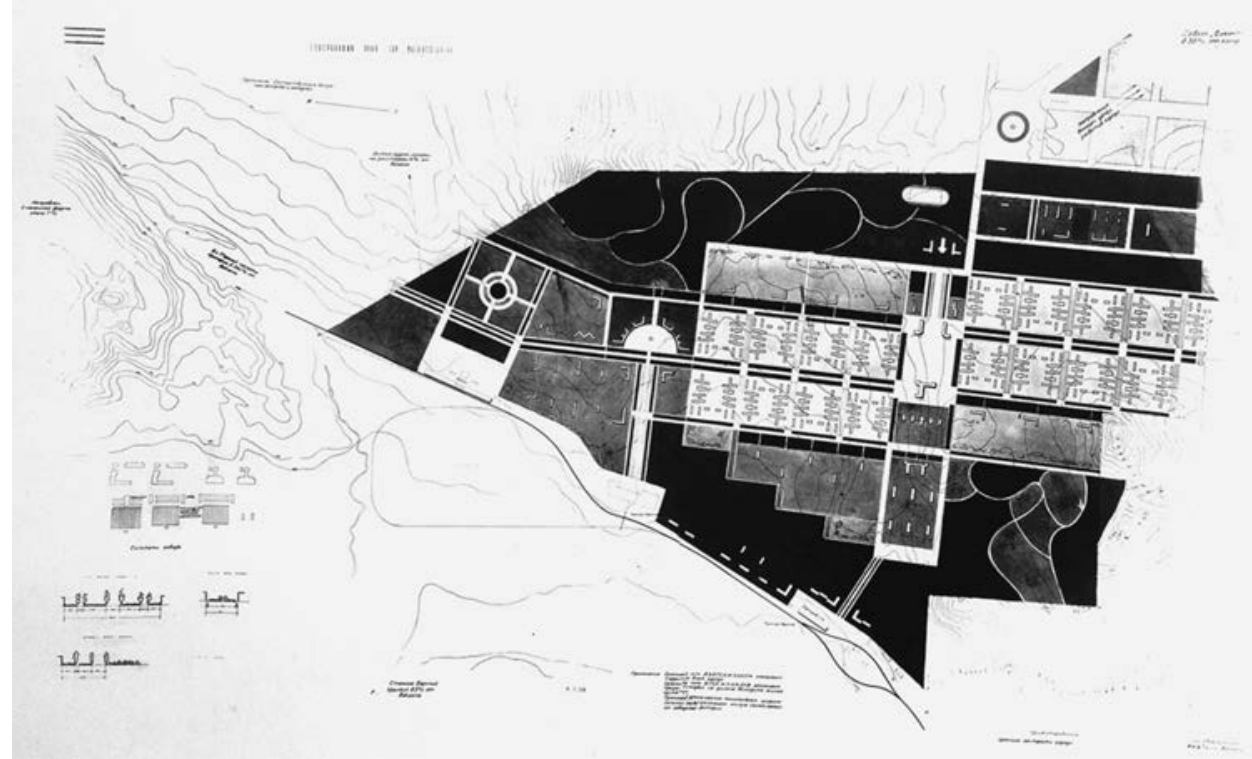

Figure 5.11. Three Lines Team sotsgorod plan, All-Union Open Design Competition for Magnitogorsk, 1930. 3rd prize. Designers: R. Val'denberg, S. Leontovich, and D. Meerson. TsDAMLM Ukrainy, f. 8, po. 1 , od. zb. 431 , ark. 63 .

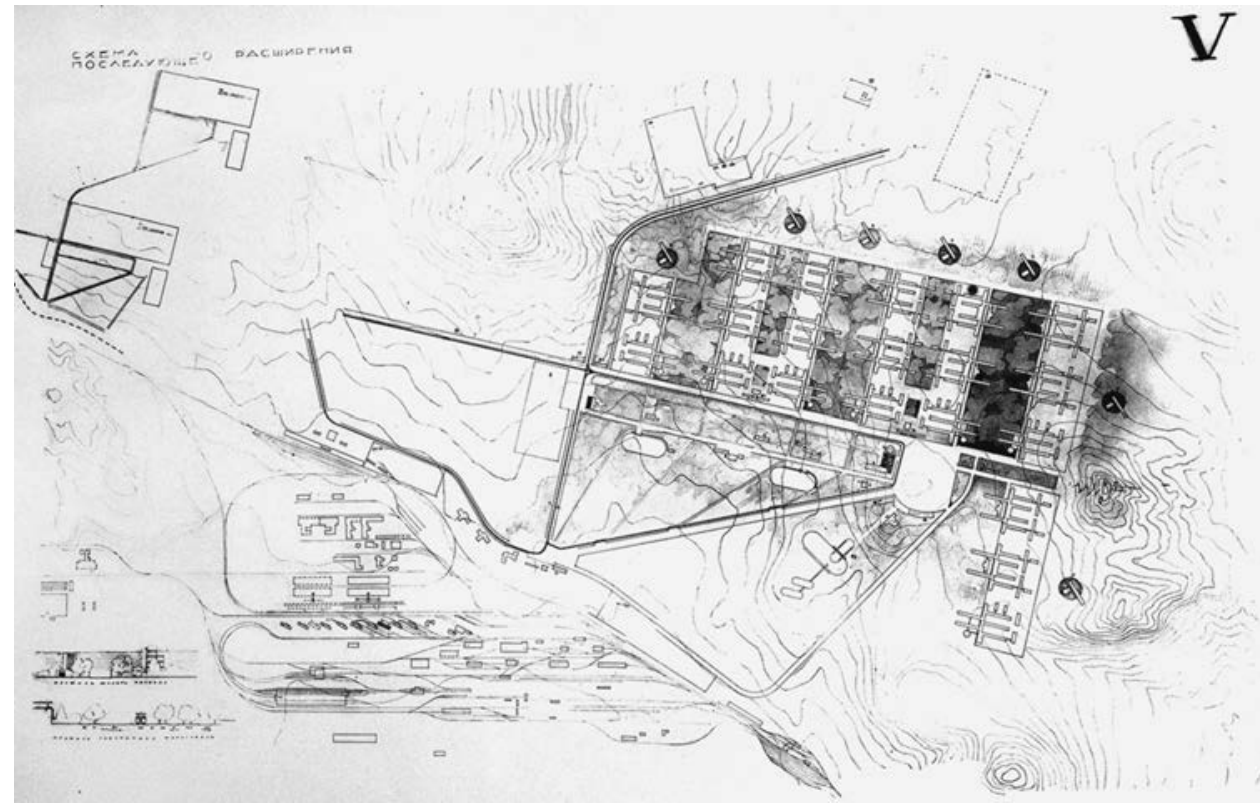

Figure 5.12. Roman Numeral Five Team sotsgorod plan, All-Union Open Design Competition for Magnitogorsk, 1930. 2nd prize (tie). Designers: R. Brilling with students of VKhTI: N. Gaicharov, M. Semenov, V. Armand, and V. Semenova. TsDAMLM Ukrainy, f. 8, po. 1, od. zb. 431, ark. 62. 


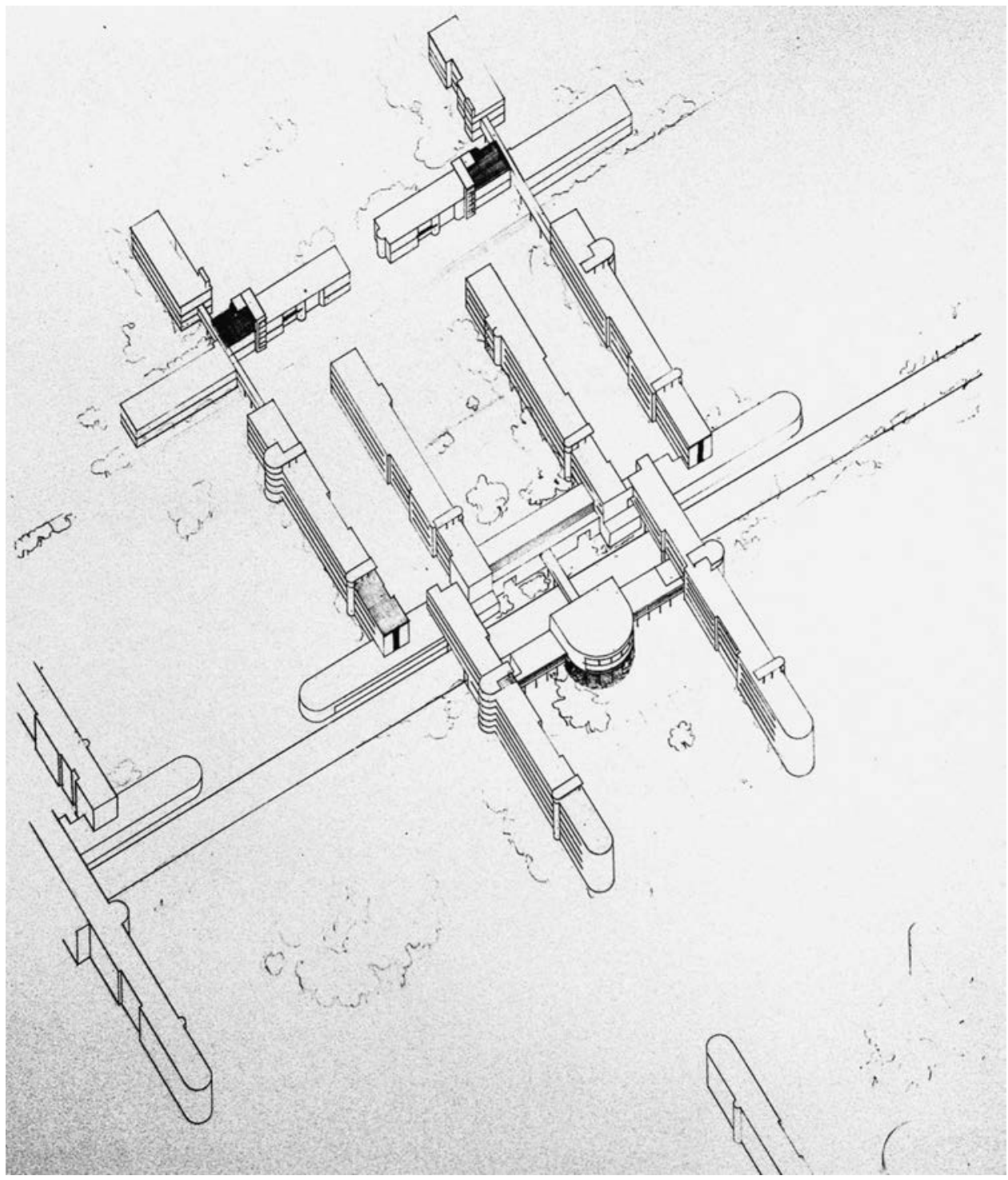

Figure 5.13. Roman Numeral Five Team zhilkombinat axonometric projection, All-Union Open Design Competition for Magnitogorsk, 1930. 2nd prize (tie). Designers: R. Brilling with students of VKhTI: N. Gaicharov, M. Semenov, V. Armand, and V. Semenova. TsDAMLM Ukrainy, f. 8, po. 1, od. zb. 431, ark. 69.

rectilinear housing bars with broad east-west faces that intersect-just barelywith perpendicular communal buildings (figure 5.13). A shared open space is captured between buildings connected by heated passageways. Dormitory schools for children of various ages fan out at the extremity of the composition and are surrounded by green space intended for gardening and animal husbandry.

The architectural and planning commonalities between these latter two submissions can be explained not only by their historical and professional context-the 
architectural language is redolent of Constructivism, ascendant in Moscow at the time-but equally by the brief itself. The programmatic requirements, population targets, four-story height cap, prerequisites of heated connections between all facilities, optimal east-west insolation, and small sleeping cells conspire to support programmatically articulated, insistently horizontal complexes of slim, linked buildings. The construction cost estimate required of each submission also forced designers to be cognizant of architectural economization. The buildings are rectilinear and aesthetically spare. The designers employed expressive rounded forms only where needed programmatically, for example in theater spaces. The brief proposed formal solutions through a combination of suggestion and requirement as similar competition entries confirm.

Although it was considered one of the most successful open entries, the jury found faults in the Black Square scheme that can be extrapolated to other concentrated city entries. At the urban scale, the jury resolved that the stretched (rastianutaia) planning of the socialist city created a "lengthy path between factory area and the institutions of public use, especially for the most distant residential communes on the opposite side of the city." The jury failed to note, or chose not to consider, that while a southeasterly-tending site plan at its most attenuated would preclude a walking commute for workers at the remote end (up to 4.7 kilometers away from the factory in the Black Square case), the fixed locations of Magnetic Mountain at the southern edge of the production zone, and the lake and river to the west, made more advantageous residential siting impossible. For the zhilkombinat design, the jury reprimanded the Black Square team for exceeding (by one floor) the fourfloor height limit set by the brief. They speculated that the relatively open ground floor of the housing bars was inspired by Le Corbusier, whose technique to raise buildings on slim columns was "often used in recent competition work." The jury determined that there was little reason to utilize such a costly detail. Lastly, they expressed dislike of the "single residential commune type." ${ }^{39}$ They were generally unsatisfied with the communes among the concentrated planning group because while they were "rational in terms of volume, they were extremely monotonous and did not address the question of insolation and the necessity for relief from such repetition." ${ }^{40}$ The jury's censure against architectural monotony comes across as a particularly unjust critique when the submitted designs are checked against the competition brief. To design a plausible residential commune to accommodate many demographic categories and programs is a challenging task under the best of circumstances. With a six-week deadline and a city to plan besides, artful deployment of a single zhilkombinat design-as the competition brief requested-was all that could plausibly be expected from entrants. The jury's disappointment with the repetition of a single commune type reflects poorly on the competition instructions and timeline more than the results. But it also prompts an important urban design question that the Soviets would grapple with for the next sixty years, namely: what 
are the psychological limits of typological standardization? Baku's Armenikend test block of 1927 was deemed a successful exemplar for residential standardization, but that may have been because it was not, in fact, repeated. The Magnitogorsk competition designs, on the other hand, demonstrated in graphic form the potential aesthetic pitfalls of scaling up superblock standardization.

\section{Visions of Dispersal and Freedom}

The OSA and Stroikom design teams elected to abide neither by the suggestions nor the requirements of the competition brief. Instead, their linear planning proposals for Magnitogorsk follow disurbanist directives set out by Okhitovich, though OSA's proposal is closer to meeting the spirit of the residential commune requested in the brief than the Stroikom proposal.

The linear scheme proposed by the OSA Brigade originates at the production zone and stretches to the southeast like the concentrated schemes, but formal and conceptual similarities end there (figure 5.14). Whereas the concentrated entries accept the singular gravitation pull of the factory, the OSA design introduces a second pole of activity: a giant collective farm (gigant-sovkhoz) twenty-five kilometers to the southeast. The OSA design is an extraordinarily attenuated residential commune that links these industrial and agricultural production areas. A dramatic single-point aerial perspective illustrates the basic structure of the design (figure 5.15). The line of settlement is divided into three equal strips along its length; the width of these strips determines a regular cadence of lines scored in the perpendicular direction to create a perfectly square mega-grid, open and ready to accept a wide variety of programmatic and formal insertions. As Andrei Gozak notes, OSA's scheme is a "model of organization," an ideogram more than a resolved urban design proposal. ${ }^{41}$ In the competition drawings and models, OSA's gridded blocks are filled with a mix of housing, cultural, and recreational facilities that include children's sectors, communications centers, and large-scale cultural and recreational facilities (figure 5.16). One repeated block holds low-rise residential buildings built of wood and glass arranged in a checkerboard pattern ( $v$ shakhmatnom poriadke) (figure 5.17). Both block and buildings imitate, at nesting scales, the grid of the site plan. Each typical checkerboard commune holds eight buildings with thirty-two residents each, for a total population of 256 . Four-story square residential buildings hold stacked pairs of sleeping units in each corner and double-height shared spaces with common bath and shower facilities, an exercise room, and spaces for collective rest and cultural work. The height of these residential buildings, the size of the individual sleeping cells, the assortment of communal programs, and the relative density of the housing here are all in line with the requirements of the competition brief. 


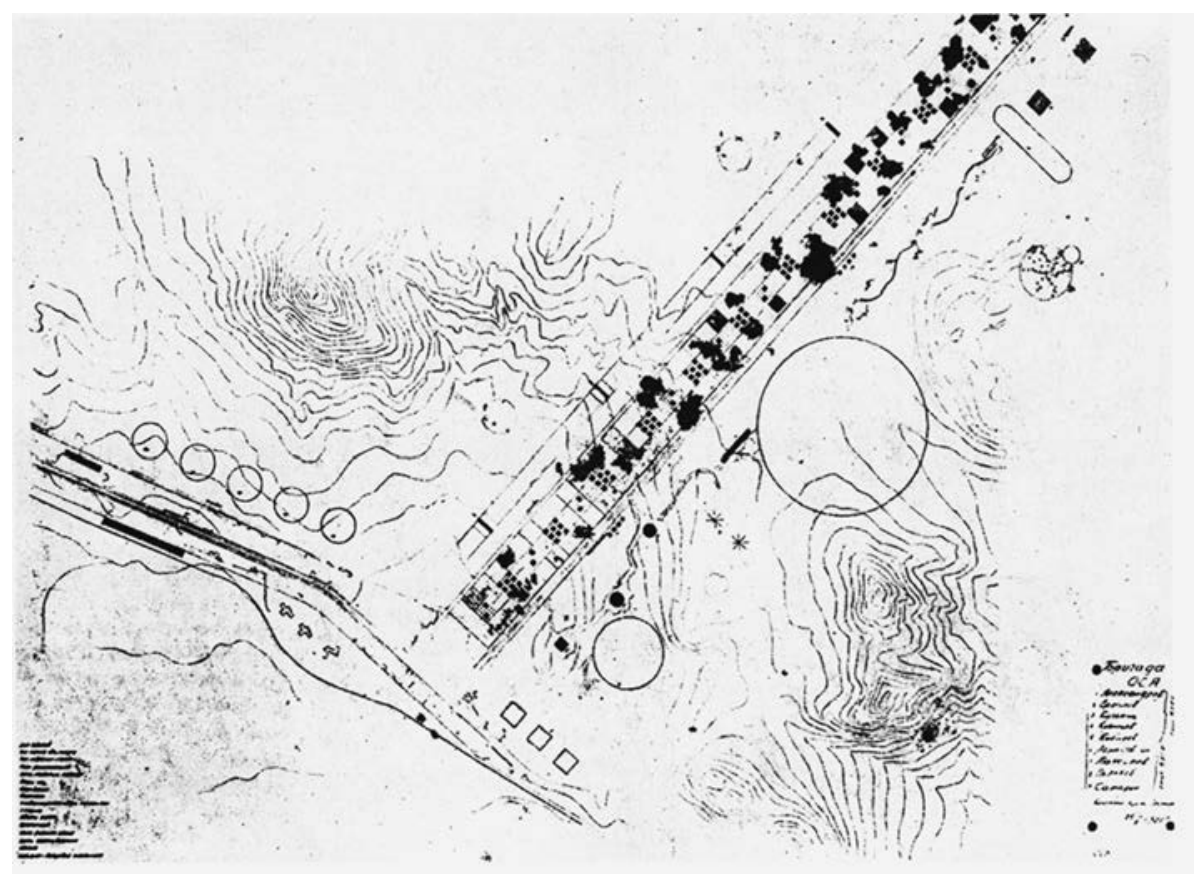

Figure 5.14. OSA Brigade sotsgorod plan, All-Union Open Design Competition for Magnitogorsk, 1930. Designers: I. Leonidov with P. Aleksandrov, A. Ermilov, S. Kibirev, G. P'iankov, S. Samarin, and Kuz'min, Kuznetsov, and Maksimov. Sovremennaia arkhitektura, no. 3 (1930), 1.
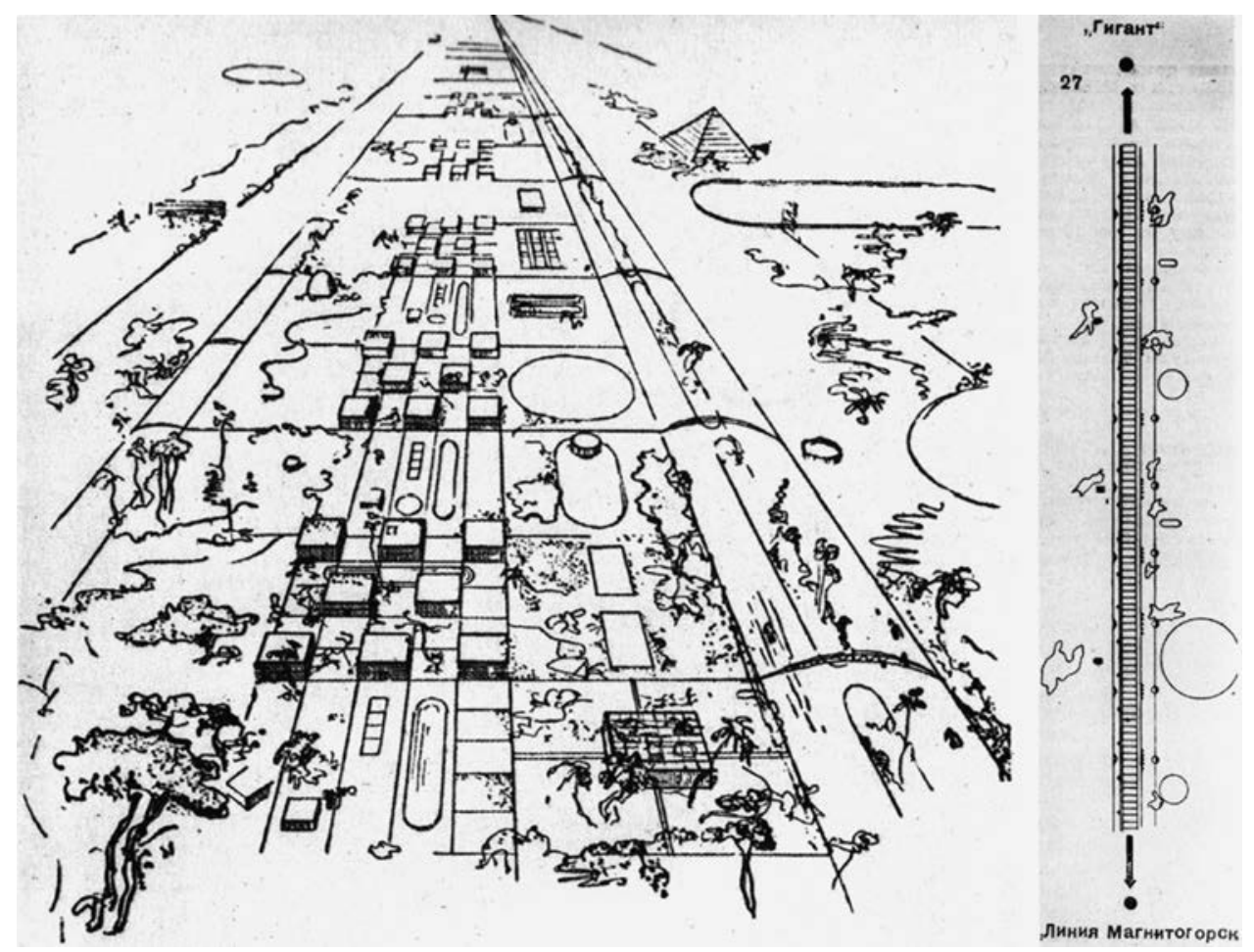

Figure 5.15. OSA Brigade perspective and diagram of the line of settlement, All-Union Open Design Competition for Magnitogorsk, 1930. Designers: I. Leonidov with P. Aleksandrov, A. Ermilov, S. Kibirev, G. P'iankov, S. Samarin, and Kuz'min, Kuznetsov, and Maksimov. Sovremennaia arkhitektura, no. 3 (1930), 3. 


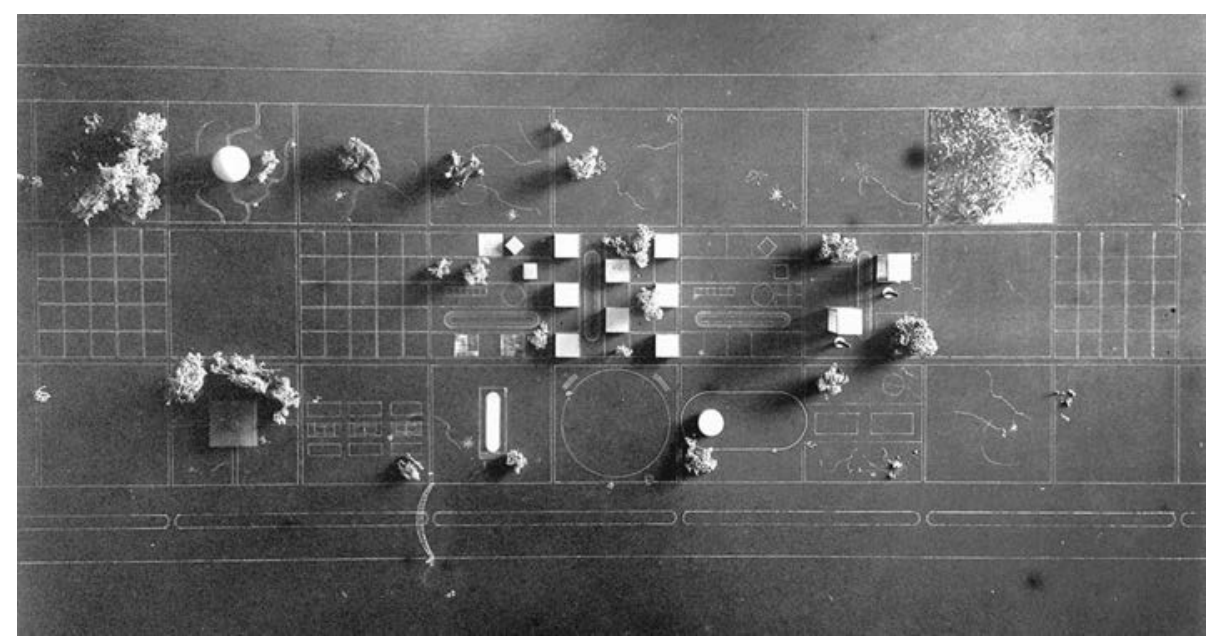

Figure 5.16. OSA Brigade model of the typical mega-grid block variations, All-Union Open Design Competition for Magnitogorsk, 1930. Designers: I. Leonidov with P. Aleksandrov, A. Ermilov, S. Kibirev, G. P'iankov, S. Samarin, and Kuz'min, Kuznetsov, and Maksimov. TsDAMLM Ukrainy, f. 8, po. 1 , od. zb. 431 , ark. 53 .

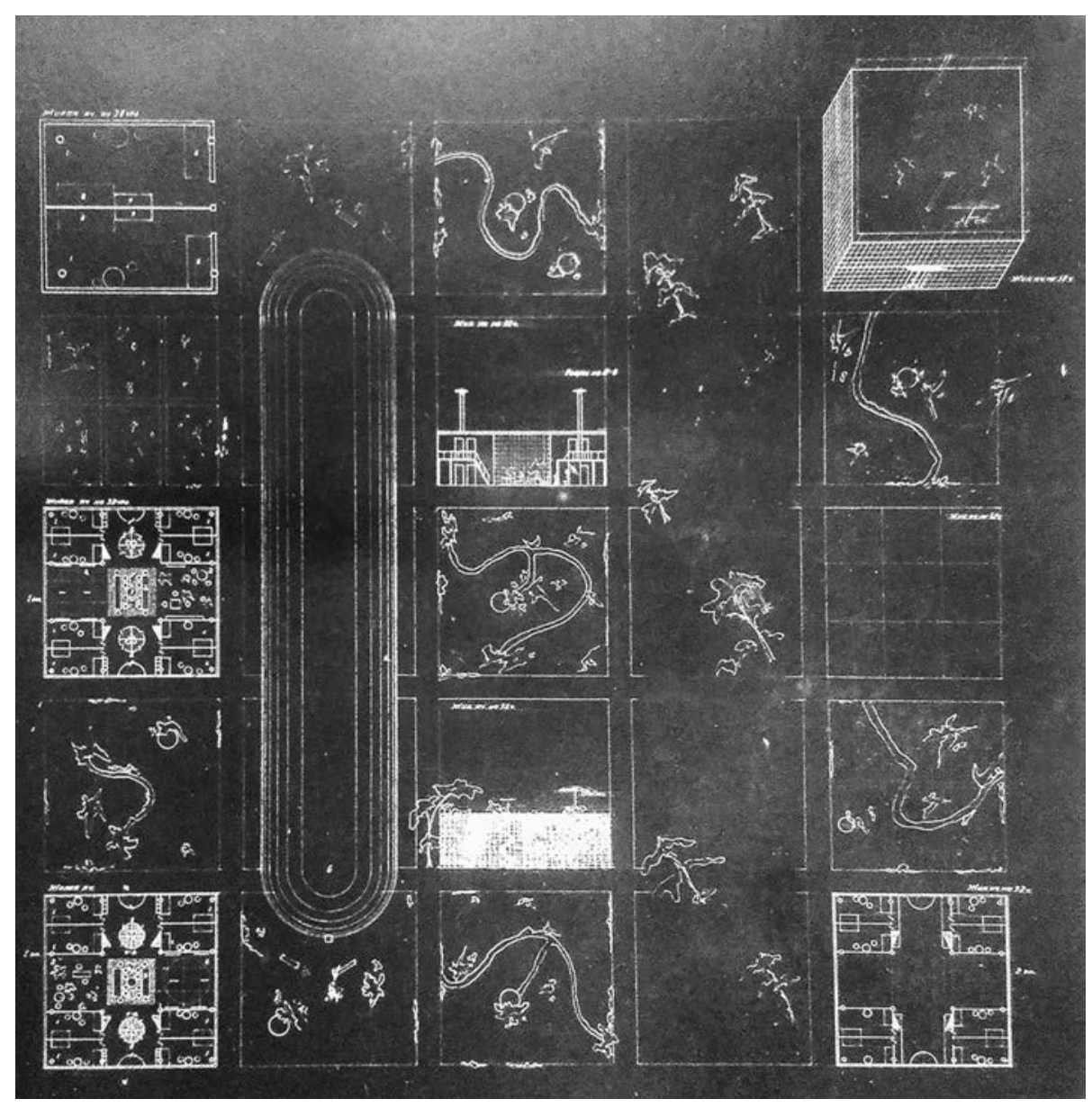

Figure 5.17. OSA Brigade model of the typical mega-grid block variations, All-Union Open Design Competition for Magnitogorsk, 1930. Designers: I. Leonidov with P. Aleksandrov, A. Ermilov, S. Kibirev, G. P'iankov, S. Samarin, and Kuz'min, Kuznetsov, and Maksimov. TsDAMLM Ukrainy, f. 8, po. 1 , od. zb. 431 , ark. 49. 
The OSA submission exceeds the brief's four-story height limit many times over in a skyscraper (neboskreb) block that is most evident in perspective drawings of the project (figure 5.18). Using the same housing floor plan as the low-rise buildings, two twenty-eight-story residential towers meet the 256-person population target of the neighboring low-rise block while retaining more open space on the ground. This high-rise planning logic was well practiced by 1930. "Towers in the park" urban schemes like Le Corbusier's Ville Contemporaine (1922) and Plan Voisin (1925) were known to the Soviet architectural community in general, and members of OSA-Le Corbusier's primary interlocutors on his visits to Moscow-in particular. The planning merits of building tall were offset by Soviet technical and economic realities, however. Steel, the future fruit of the Magnitogorsk industrial complex, was a rare commodity in 1930, and one earmarked for industrial, not residential, construction.

While OSA's submission was original, spatially dynamic, and evocative, it was plagued by questions of feasibility. As the jury noted, municipal services, transportation, and communications would be difficult to supply in such an attenuated

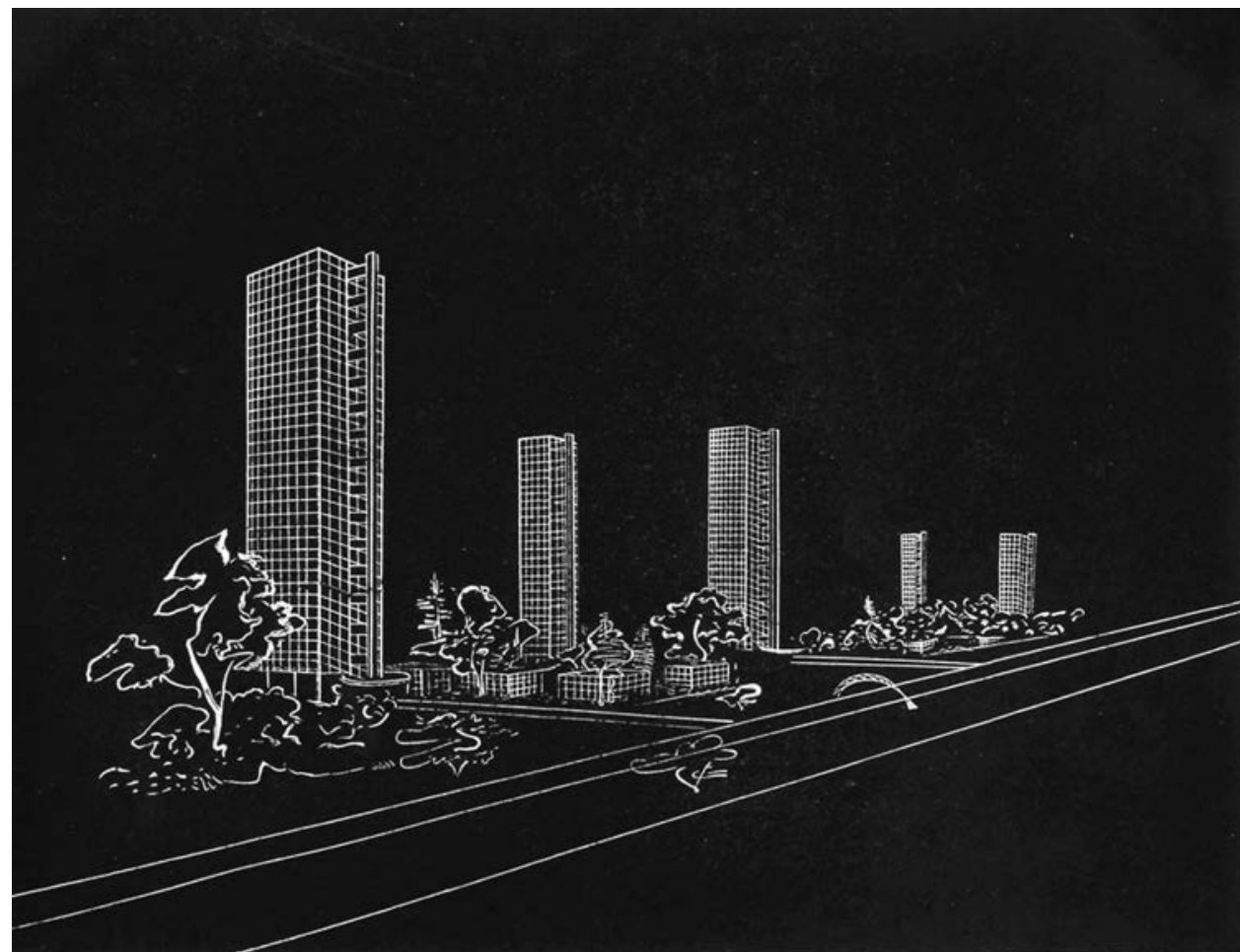

61. ОВщНH BHД ПOCEIRA. HEБOCKРEБЫ.

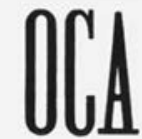

Figure 5.18. OSA Brigade residential perspective, All-Union Open Design Competition for Magnitogorsk, 1930. Designers: I. Leonidov with P. Aleksandrov, A. Ermilov, S. Kibirev, G. P'iankov, S. Samarin and Kuz'min, Kuznetsov, and Maksimov. TsDAMLM Ukrainy, f. 8, po. 1, od. zb. 431, ark. 51. 
development. In the journal Stroitel'stvo Moskvy (Moscow construction) the architect Nikolai Dokuchaev added a formal critique of the scheme when he asked, "how, in the random and chaotic distribution of the residential and communal buildingswhich is interesting only as an image-are we supposed to see a novel solution to the socialist city, instead of just another village of some self-build dacha association?"42 But it is precisely the open and readily transformable framework of the mega-grid that places this scheme in opposition to traditional fixed-goal general planning. The OSA scheme is a skeletal framework that allows for varied possibilities and transformation over time. It is, most important, an organizational infrastructure that welcomes the process of dispersal over large territories that Okhitovich called "disurbanization."

Okhitovich himself, joined by architects Mikhail Barshch, V. Vladimirov, and N. Sokolov, authored the linear Stroikom submission. Their general plan, titled "A New Resettlement of Mankind" (novoe rasselenie chelovechestva), is drawn at a scale much larger than the 1/5000 required by the competition brief because the scheme is premised on regional, not city, planning (figure 5.19). ${ }^{43}$ The industrial production zone at the center is supported by multiple agricultural zones twentyfive kilometers or more remote from the factory complex. The roads to connect industry and agriculture are the lines along which diffuse settlement will develop. On the general plan and project diagrams, these eight settlement ribbons (lenty) register as dark lines that radiate from the southern shore of the industrial lake and the production zone. A long multi-sheet drawing describes the constituent elements of a typical ribbon (figure 5.20). An automotive road runs down the center of the sinuous line. A communal service building at each kilometer (the so-called kilometer station) holds a canteen, provisions store, library, barber/hair salon, garage, and two motorcycles for communal use. Nurseries, boarding schools, and public recreational facilities flank the station (figure 5.21).

Fine-grained organization in the Stroikom scheme is loose and driven by personal choice, in keeping with Okhitovich's philosophy that socialism leads to individual freedom. Each socialist citizen should have the right, explained the design team, "not only to impact the collective, but also to deepen work on himself. Not only to engage in public action, but also in concentrated thinking." The architectural vessel for introspective self-improvement is the stand-alone living cell (zhilaia iacheika), a single occupancy cube sitting on thin columns that looks out over the landscape (figure 5.22). Any citizen could build the simple and lightweight living cell using structural elements kept on hand at the kilometer station. Location, orientation, and proximity to other cells would be a matter of personal preference. As the diagrams and axonometric view reveal, the system does not preclude communal living. The cells can be constructed in clusters, rendering density and communality a choice in the Stroikom scheme. To underscore once and for all the conceptual distinction between urbanist proposals that force shared living in a single large structure and this disurbanist scheme of cellular units, the Stroikom team adopted the motto: "not a house-commune, but a commune of houses." 4 


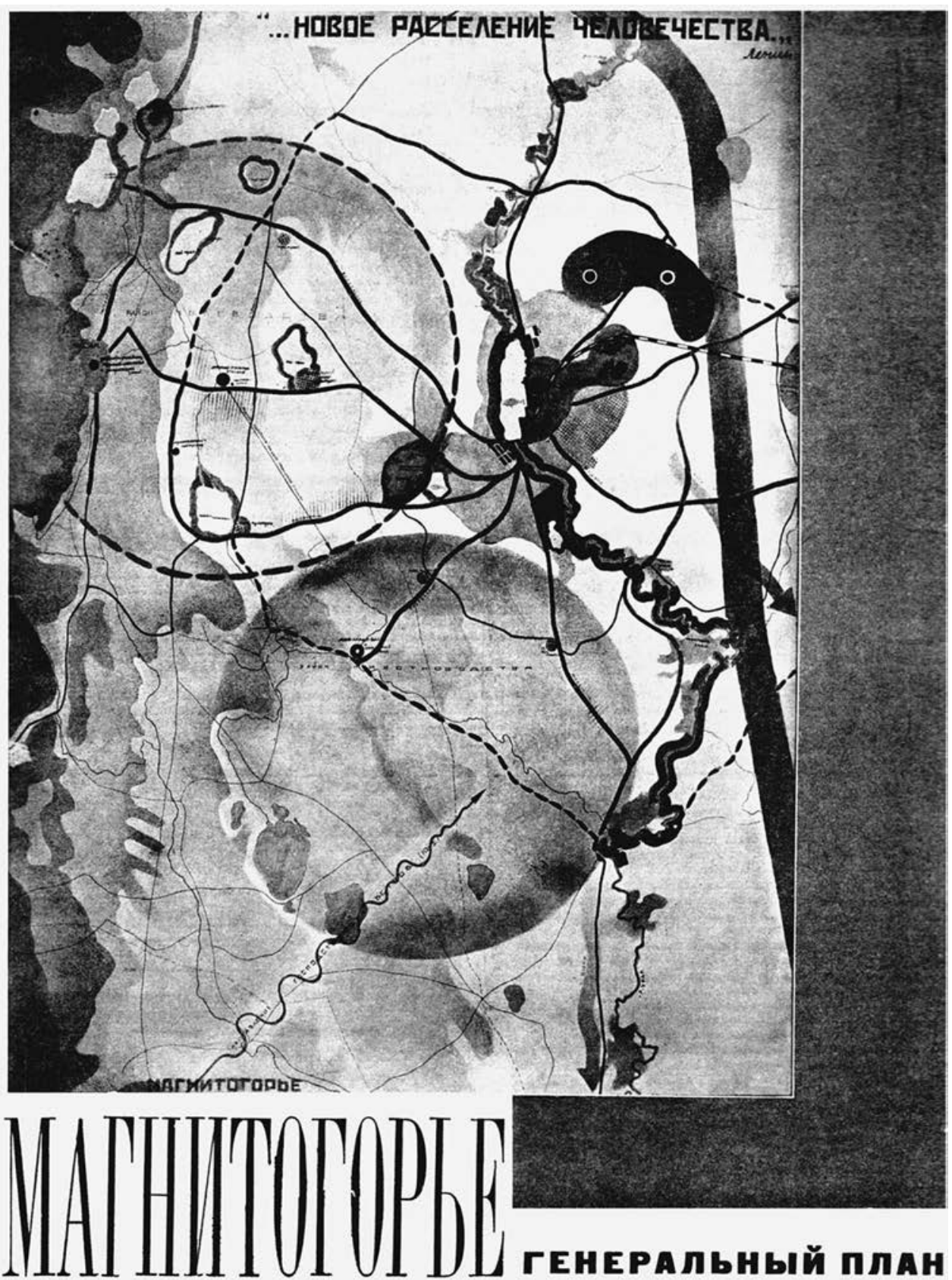

Figure 5.19. Stroikom RSFSR team general plan, All-Union Open Design Competition for Magnitogorsk, 1930. “New Resettlement of Mankind-Lenin.” Designers: M. Barshch, V. Vladimirov, M. Okhitovich, and N. Sokolov. Sovremennaia arkhitektura, no. 1-2 (1930), 39.

Dokuchaev homed in on a common critique of the Stroikom scheme. "A little individual house [on stilts], with a personal auto beneath, is the authors' solution to the Leninist charge to create 'a new resettlement of mankind which destroys 


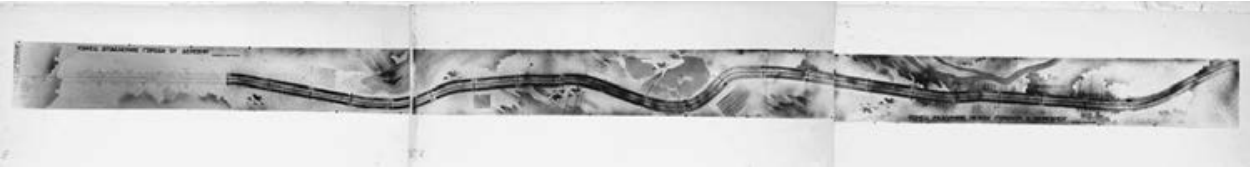

Figure 5.20. Stroikom RSFSR team, typical resettlement ribbon plan, All-Union Open Design Competition for Magnitogorsk, 1930. Inscribed on the drawing are the maxims "End of the separation of city and countryside-Marx-Engels" and "End of the distinction between city and countryside-Marx-

Engels.” Designers: M. Barshch, V. Vladimirov, M. Okhitovich, and N. Sokolov. TsDAMLM Ukrainy, f. 8 , po. 1 , od. zb. 431 , ark. 58 .

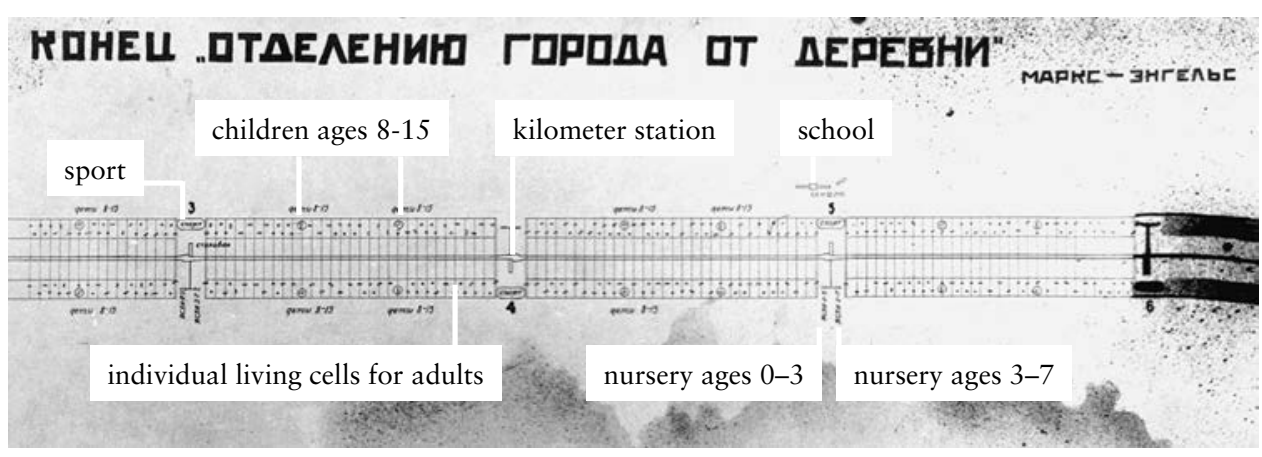

Figure 5.21. Stroikom RSFSR team, typical resettlement ribbon plan detail, All-Union Open Design Competition for Magnitogorsk, 1930. Designers: M. Barshch, V. Vladimirov, M. Okhitovich, and N. Sokolov. Diagram by the author based on TsDAMLM Ukrainy, f. 8, po. 1, od. zb. 431, ark. 57.

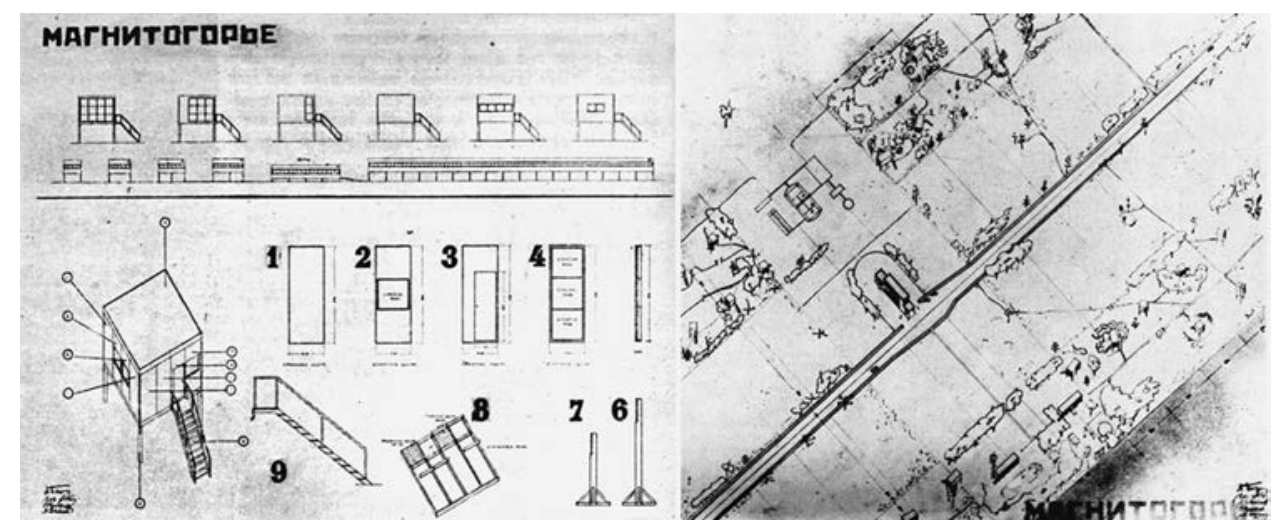

Figure 5.22. Stroikom RSFSR team, axonometric of urban scheme (left), and standard elements of the individual living cell (right), All-Union Open Design Competition for Magnitogorsk, 1930 Designers: M. Barshch, V. Vladimirov, M. Okhitovich, and N. Sokolov. Sovremennaia arkhitektura, no. 1-2 (1930), 44, 48 .

rural backwardness and isolation, and the inhumane concentration of masses in the large cities.' Here, the little house is cut off from urban density, and the auto abolishes rural isolation. A truly 'genius' answer to the problem." ${ }^{45}$ Dokuchaev's snide remarks aimed at Okhitovich's chief spatial principle of "to every worker and laborer-his own space." ${ }^{\prime 6}$ In the socialist urbanism debates taking place 
in Moscow at the end of 1929, there was a general consensus that collective living was the ultimate goal for Soviet society; only the timeline for and degree of change was unresolved. The free-floating individual living cells designed by Stroikom for Magnitogorsk simply flew in the face of prevailing logic at the time. They are not urban, dense, or collective. Further, the resonant image for the Stroikom scheme-the stand-alone elevated box-looks and acts nothing like the residential commune requested in the competition brief or any of the other entries to the competition. Sabsovich landed the most direct, if childish, hit against Stroikom's living cell by referring to it as an "izba on chicken legs" (izba na kur'ikh nozhkakh). ${ }^{47}$

Surprisingly, the jury reacted more favorably to the rule-breaking submissions than to those that met the brief's requirements. They declared that although linear settlements were still untested in practice, the proposals' only significant defect was their considerable length, for which "the issues of electrification, telephony, and water supply would be difficult and expensive to resolve." ${ }^{\prime 4}$ Linear settlement systems and their housing types were, furthermore, "truly interesting and positive ideas that fully answer Lenin's decree for the task of socialist settlement." And although "not one made an entirely detailed design project for the city," the jury nonetheless proposed that a small section of either the OSA or Stroikom design be installed as an experiment in Magnitogorsk. ${ }^{49}$ Both linear schemes do share a common commitment to process over totalizing vision and to granular versus monumental construction. These characteristics made it possible for the jury to imagine implanting one of the linear proposals as a seed project that could grow and be tested with time.

\section{What Now?}

After all of the collaborative energy exerted by individuals and groups on both sides of the Magnitogorsk competition-to craft the perfect brief, to design the model settlement, to select the most promising vision for socialist urbanism-the results were disappointingly inconclusive. The jury found that the submitted proposals "did not fully satisfy the requirements of the competition brief, and further, that among the total number of projects submitted, six did not satisfy the competition requirements even on formal grounds." In addition, they determined that "all of the projects proposed were unsatisfactory with regard to the socialization of everyday services for the population." Based on this assessment, the jury opted not to award a first-place prize. Two second-place awards were given, as well as a third- and two fourth-place awards. In an apparent effort to temper their critique, the jury concluded that because Magnitogorsk was "the first experiment in constructing new cities, the whole competition provided positive results which we will be able to use in future studies." 50 
The jury's unenthusiastic response to the submissions meant that the competition was of no service to the residents of Magnitogorsk insofar as it yielded no officially endorsed project to construct. The Magnitostroi administration disregarded the jury's recommendation to implant a fragment of one of the linear schemes on site, and the concentrated city entries likewise remained on paper. Despite the competition organizers' and participating designers' best efforts, the socialist city of Magnitogorsk was no closer to being built in March 1930 than it had been in January.

The jury's prediction that the Magnitogorsk competition was a "first experiment" likely to prompt more theorizing, discussion, and (ultimately) construction was accurate, however. In his book Sotsgorod, published soon after the competition, vice chair of the jury, Nikolai Miliutin, rolled out his own urban model he called the Linear City. ${ }^{51} \mathrm{He}$ included in the book diagrams of the Black Square, OSA, and Stroikom schemes for the Magnitogorsk competition as close, but imperfect, predecessors to his model. His own proposal "for a plan according to the functional-assembly-line system" was a "correction" of the plans of OSA and Stroikom and was "devoid of their shortcomings" (figure 5.23). ${ }^{52}$ Miliutin's version runs north-south along the left bank of the lake. The program is distributed in strict linear bands starting with the Ural River, followed by a park, a residential sector, a green buffer, and finally the industrial zone, which is bordered at the far eastern edge by a rail line. Members of the jury were strictly forbidden from participating

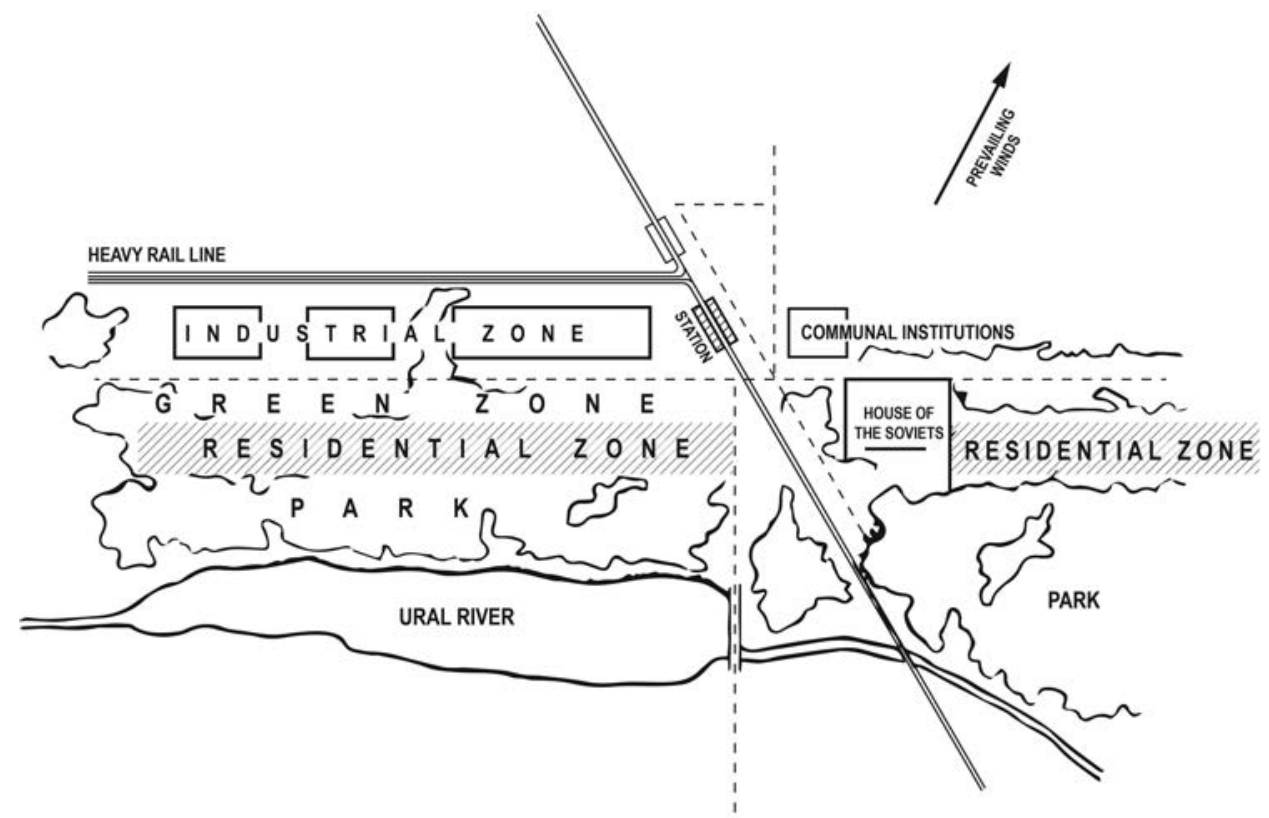

Figure 5.23. A site plan diagram for a linear city at Magnitogorsk, Nikolai Miliutin, 1930. Diagram by the author based on N. A. Miliutin, Sotsgorod: Problema stroitel'stva sotsialisticheskikh gorodov (Moscow: Gosudarstvennoe izdatel'stvo, 1930), 28. 
in the competition even as consultants, so this scheme was purely speculative and designed after the fact. ${ }^{53}$ Its purpose seems to have been to introduce readers to the idealized linear city model as tested on a well-known site recently covered in detail by the Soviet press.

In 1931, the German architect Ernst May, generally a proponent of linear planning, dismissed Miliutin's speculative proposal for Magnitogorsk. By then, May had learned for himself that topographical and industrial conditions on the site prohibited a clean linear solution like Miliutin's. May wrote that “quite obviously, the linear city is to a large extent influenced by local geographical conditions. For instance, Miliutin's proposal would not work for the city of Magnitogorsk, simply because the terrain there is restricted by the fourteen-kilometer-long dam on the one side and the iron-ore mountain on the other, thus precluding any kind of parallel development." ${ }^{54}$ The competition entrants, and eventually May, came to understand that physical realities stood in the way of easy solutions. Magnitogorsk was not at all a tabula rasa site. Contextual conditions would drive the city's design.

Did the Magnitogorsk competition brief, the primary instaurational text of the first Five-Year Plan, act as a mechanism for generating built space? Yes, and no. Yes, because from its opening operational principles to its concluding salvo of detailed requirements, the brief sparked the pivotal creative task of the first Five-Year Plan, namely the formulation of a buildable, replicable model socialist urban form. It conjured an image of future socialist space in the mind's eye before pencil was put to paper through its treatise-like framework of ground rules and utopian-ready set of architectonic details. The competition designs that resulted from the brief, especially the concentrated city examples, share remarkable organizational and formal similarities because the text specifically directed the creative work. No, because despite the creative output that resulted from the text, the competition did not generate actual built space on the site for which it was written.

Unlike Baku, and Kharkiv to come, where on-the-ground research and construction led to real-time development of new design processes, urban relationships, and architectural forms, the socialist city competition for Magnitogorsk was largely an intellectual project. Magnitogorsk prompted more theoretical and less material activity than the other two sites for a number of reasons, but perhaps most saliently for the prosaic facts of geographical distance and intensity of the industrial construction project. Because it was so remote-over four days from Moscow by train-few of the officials or designers charged to plot its future set foot on the site. This distance permitted the material fact of the Magnitogorsk sotsgorod to be deferred in favor of its conceptual potential. In addition, the factory complex was perpetually siphoning funding, workers, and materials from the residential quarter. 
Although the gap between intellectual work and actual construction was undoubtedly a tribulation for the workers living in substandard housing on the Ural steppe, it would be unjust to brand the theory generated in the name of Magnitogorsk a failure. If we choose to characterize the All-Union competition brief as an instaurational text-the purpose of which was to stimulate the development of model spatial solutions-it is possible to judge the competition positively, even though it produced no winning scheme. The text did drive the development of urban and architectural types by the next round of designers hired to solve the Magnitogorsk sotsgorod: the Soviet architect Sergei Chernyshev and the German architect Ernst May. 


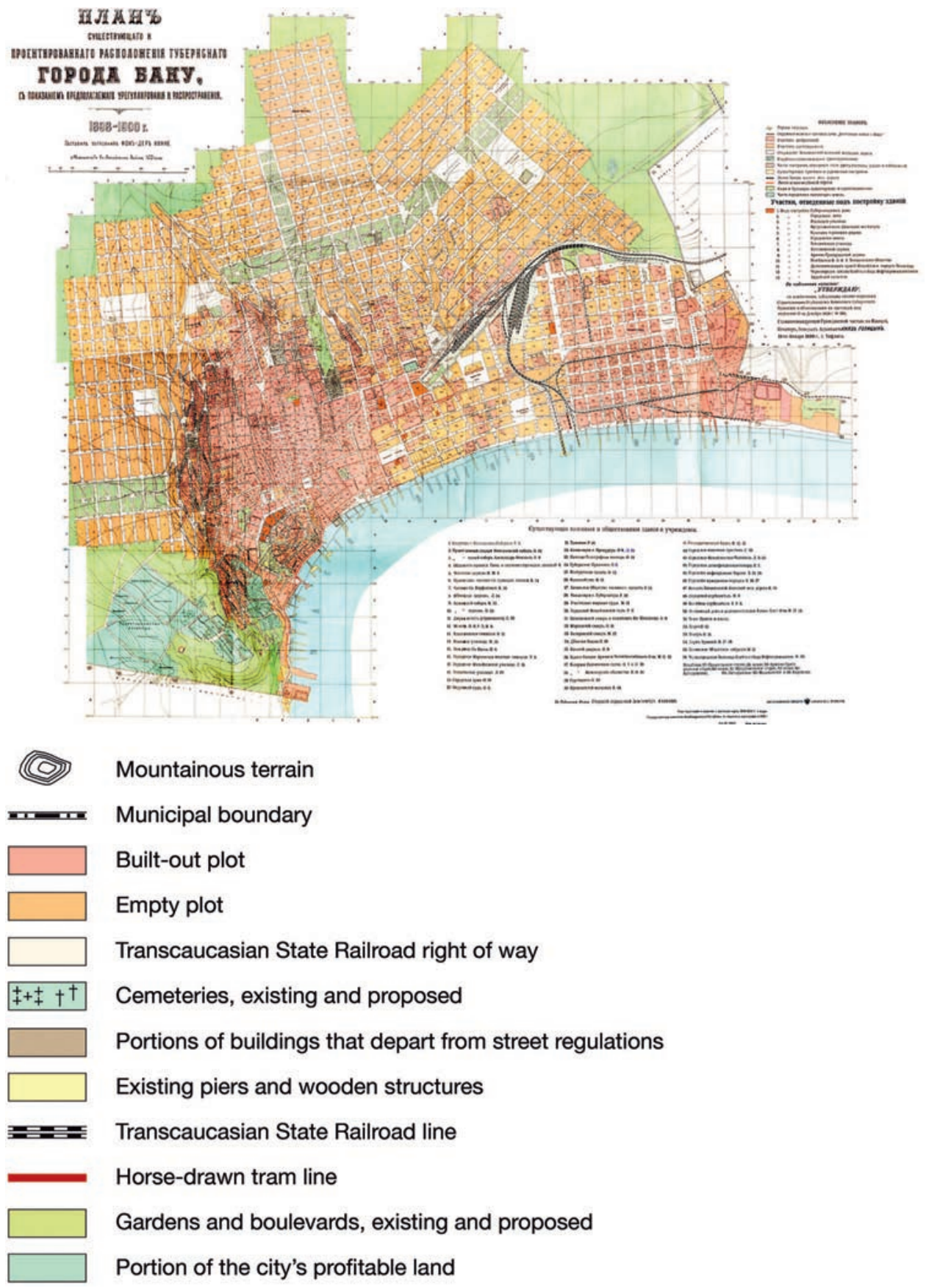

Plate 1. A plan for the City of Baku, Azerbaijan, 1898. Planner: Nikolaus von der Nonne. Library of Congress, Geography and Map Division, G7144.B2 1900. F6 1992 MLC. CC-PD-Mark. Key diagram by the author. 


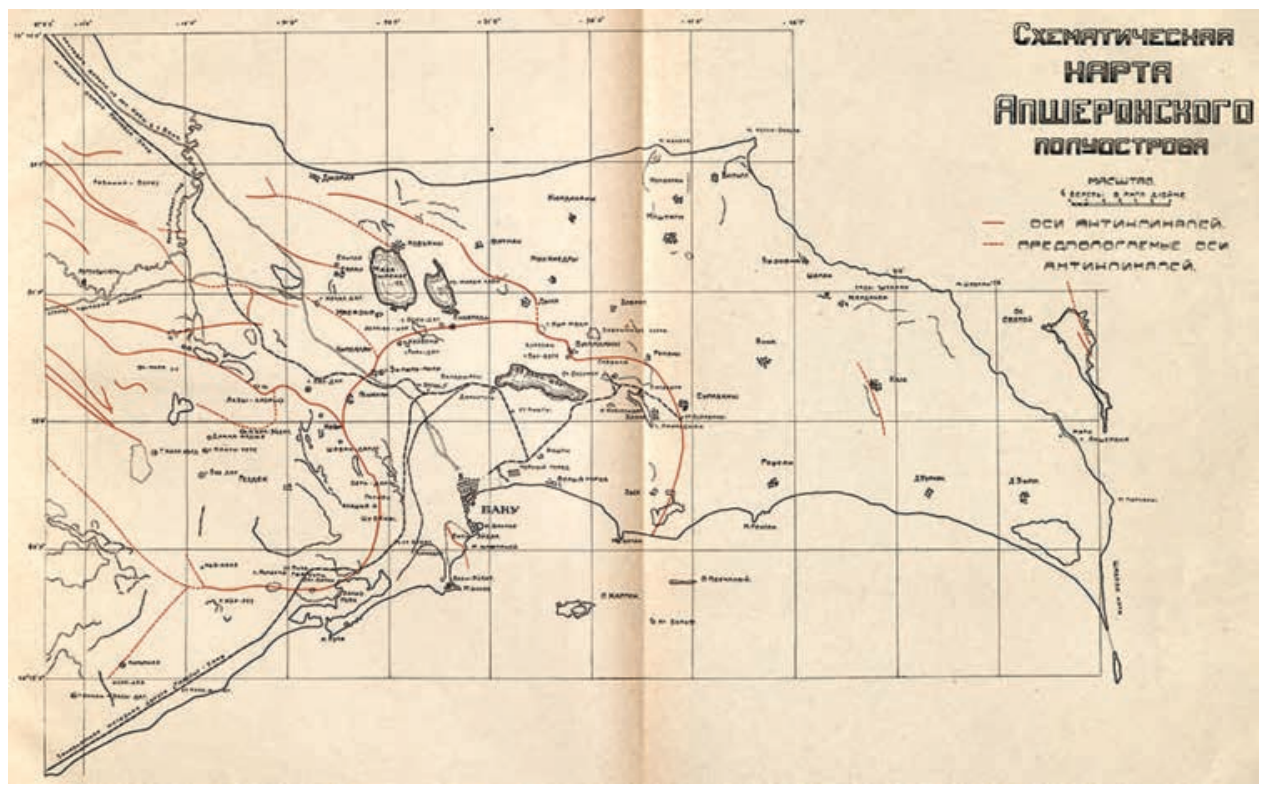

Plate 2. A schematic map of the Apsheron Peninsula. Red lines trace the anticline axes, geological folds along which oil and gas drilling is most productive. Azneft, Obzor Azerbaidzhanskoi neftianoi promyshlennosti za dva goda nationalizatsii: 1920-1922 (Baku: Azneft, 1922).

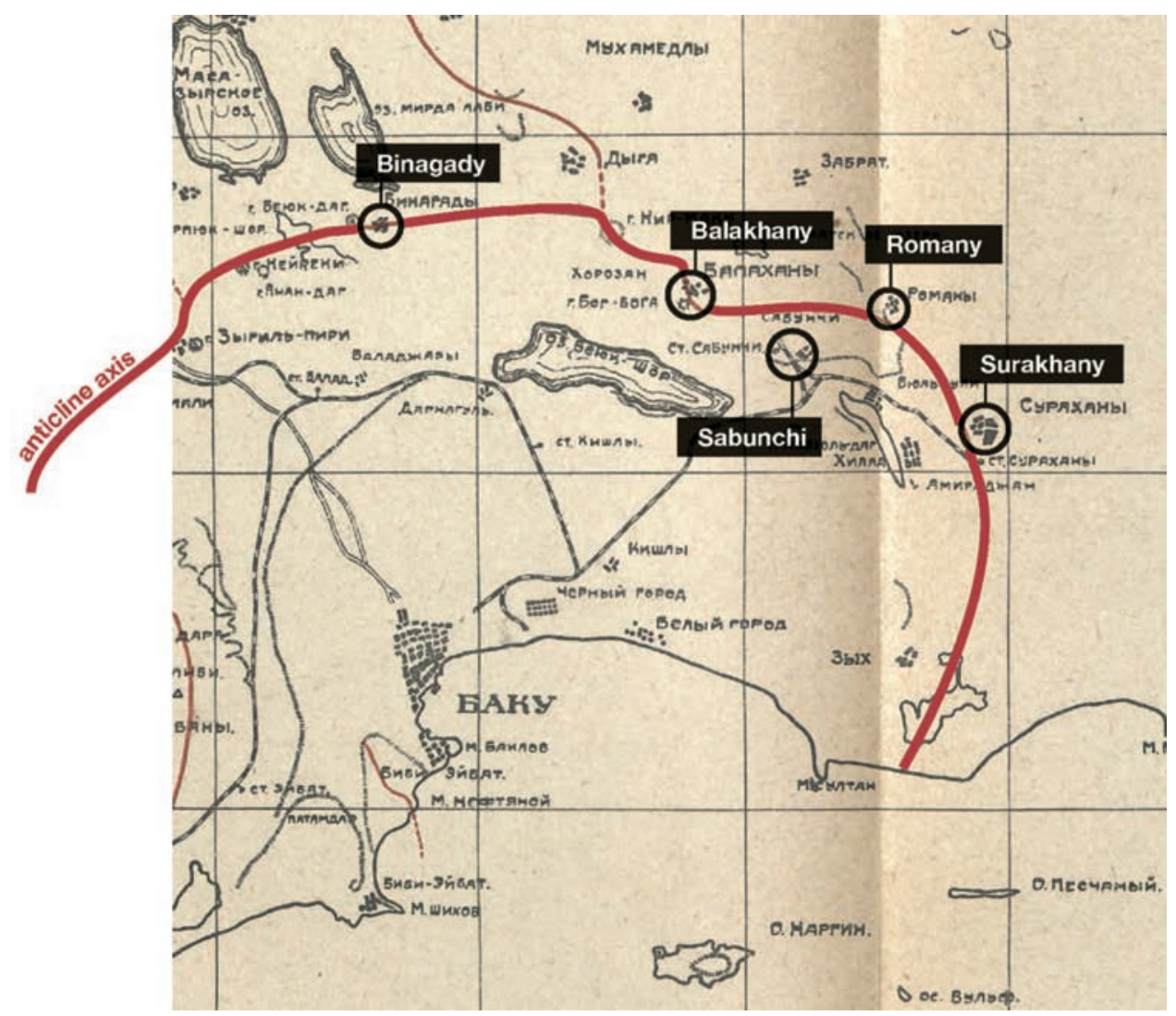

Plate 3. Map detail showing the location of pre-Soviet worker villages that sit directly on the cherished fault line. Diagram by the author based on the map in Azneft, Obzor Azerbaidzhanskoi neftianoi promyshlennosti za dva goda nationalizatsii: 1920-1922 (Baku: Azneft, 1922). 


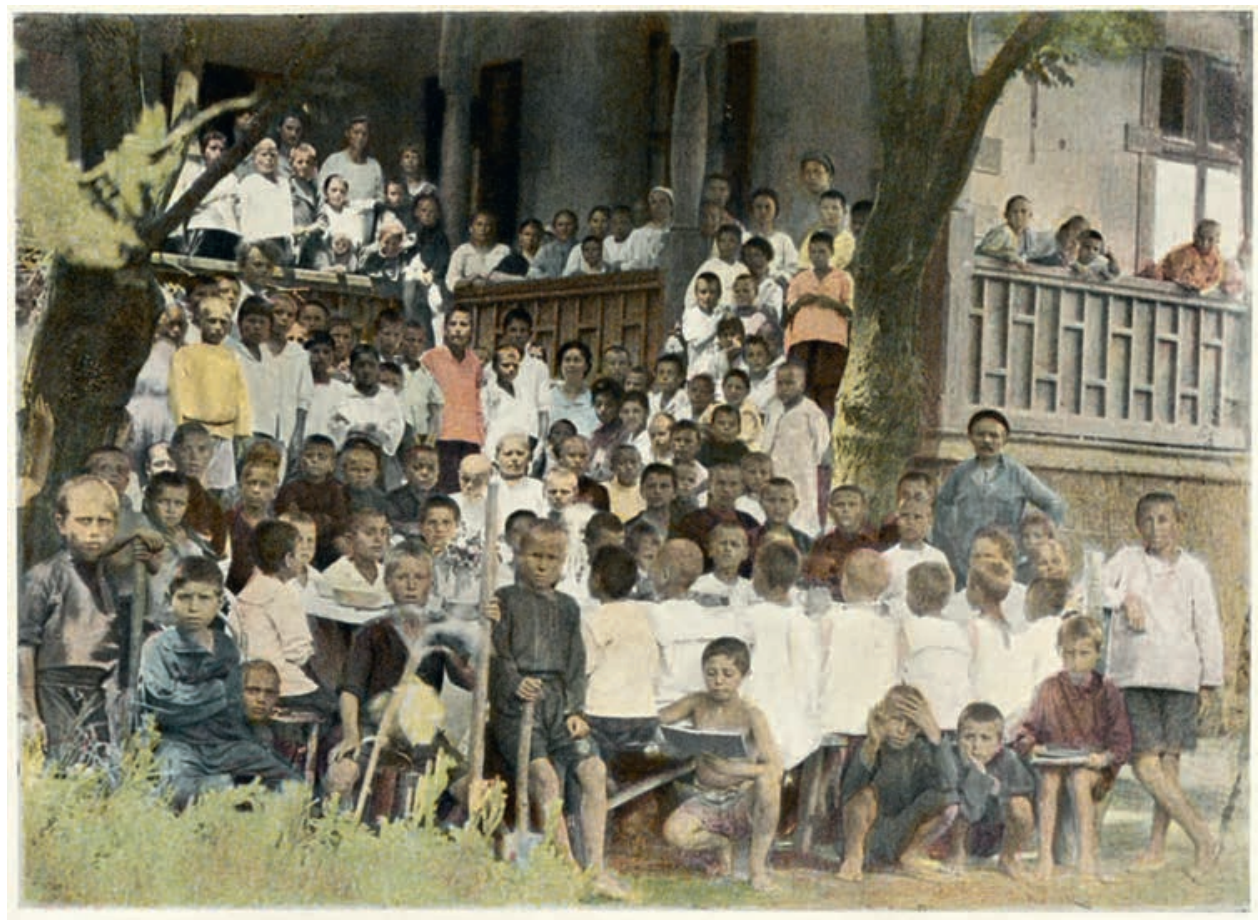

Аом отдыха для детей нефтеработников в Белом городе

Plate 4. House of rest for the children of oil workers in the White Town, Baku. Azneft, Obzor Azerbaidzhanskoi neftianoi promyshlennosti za dva goda nationalizatsii: 1920-1922 (Baku: Azneft, 1922), 265. 


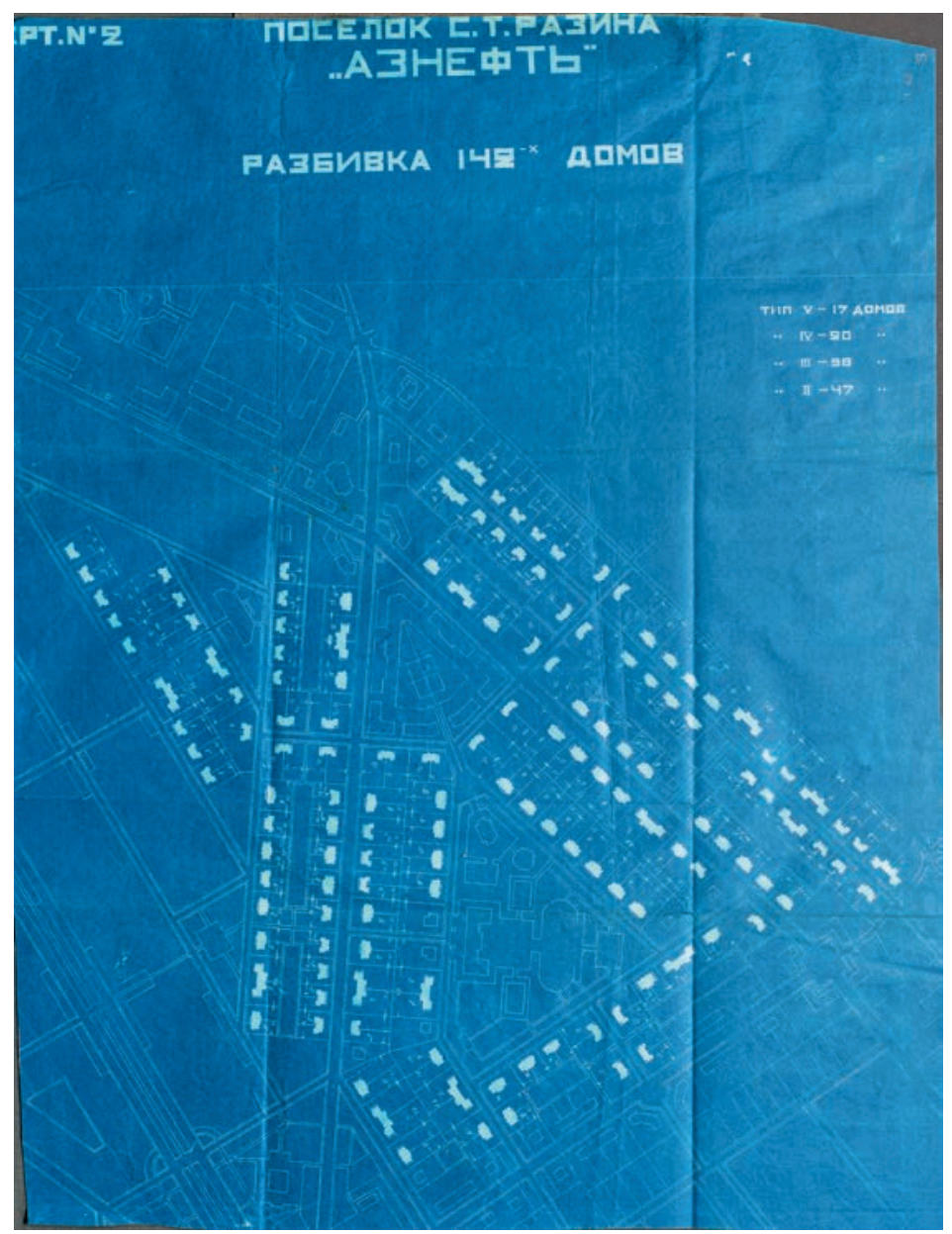

Plate 5. Site plan of the 142 houses planned for the first phase of construction in the Azneft Stepan Razin settlement, 1925. Planners: Aleksandr Ivanitskii, Viktor Vesnin, Leonid Vesnin, et al. RGALI, f. 2991, o. 1, d. 17, 1. 10.

Plate 6. A detailed plan of the four primary worker housing types and their quantities planned for the first phase of construction in Azneft's Stepan Razin settlement, 1925. Planners: Aleksandr Ivanitskii, Viktor Vesnin, Leonid Vesnin, et al. Diagram by the author based on RGALI, $\mathrm{f}$.

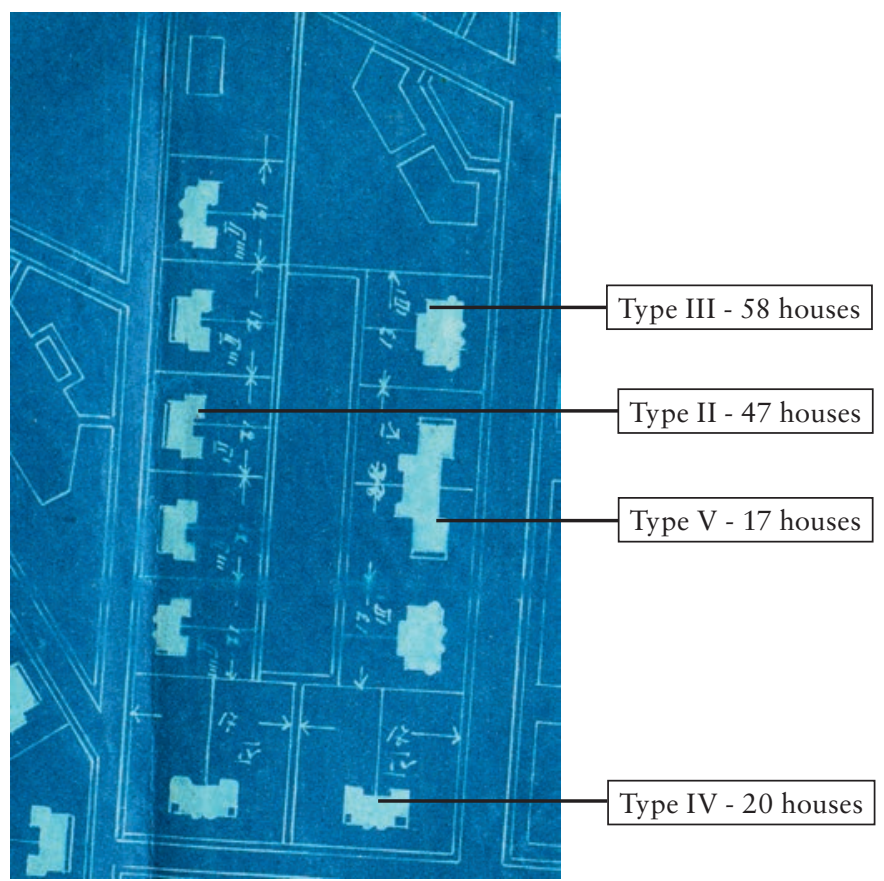
2991, o. 1, d. 17, 1. 10. 


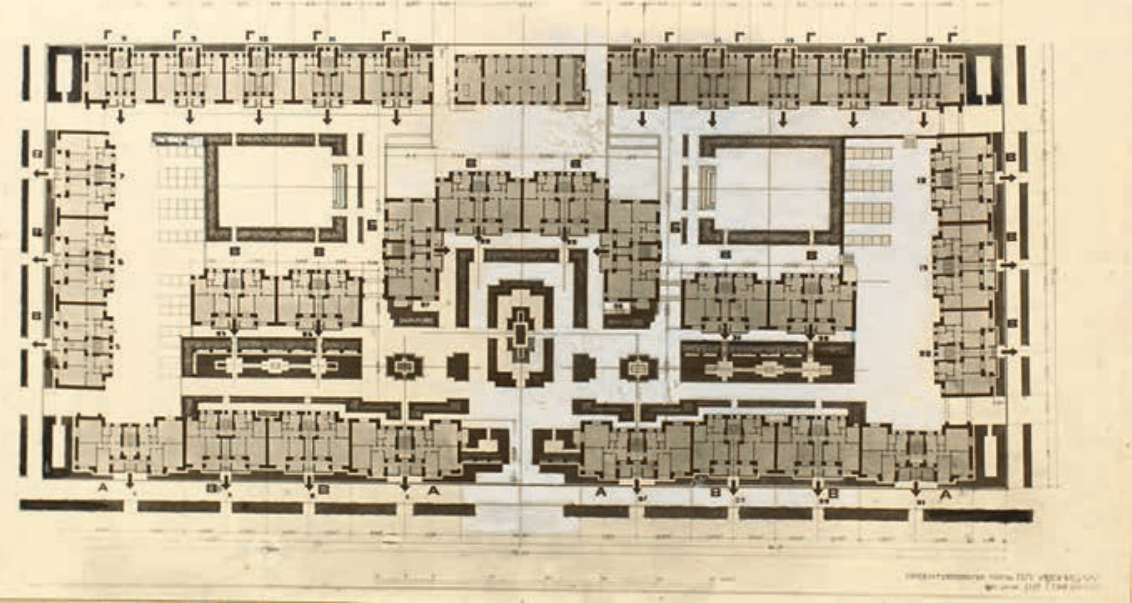

Armenikend Test Block 171 Approved unit mix

3-story buildings

174 apartments

300 families

shared laundry building

playgrounds + garden plots
Living norms + dimensions Type A (3-room/2-family, 27.5\%): 48 units 240 s.m. average / unit Types Б/B (2-room/2-family, 45\%): 78 units 138 s.m. / family Type $\Gamma$ (1-room/1-family, $27.5 \%$ ): 48 units 7.6 s.m. / person $22.8 \mathrm{cu} . \mathrm{m} . /$ person 51 s.m. open space / person

Plate 7. Armenikend Test Block (Block 171), Baku, Azerbaijan, 1927. Architects: Aleksandr Ivanitskii, Anatolii Samoilov, et al. RGALI, f.2991, o.1, d.17, 1.87. Detailed information about the block, unit numbers, and mix from ARDA, f. 1933, o. 1, d. 353, 11. 29-37.

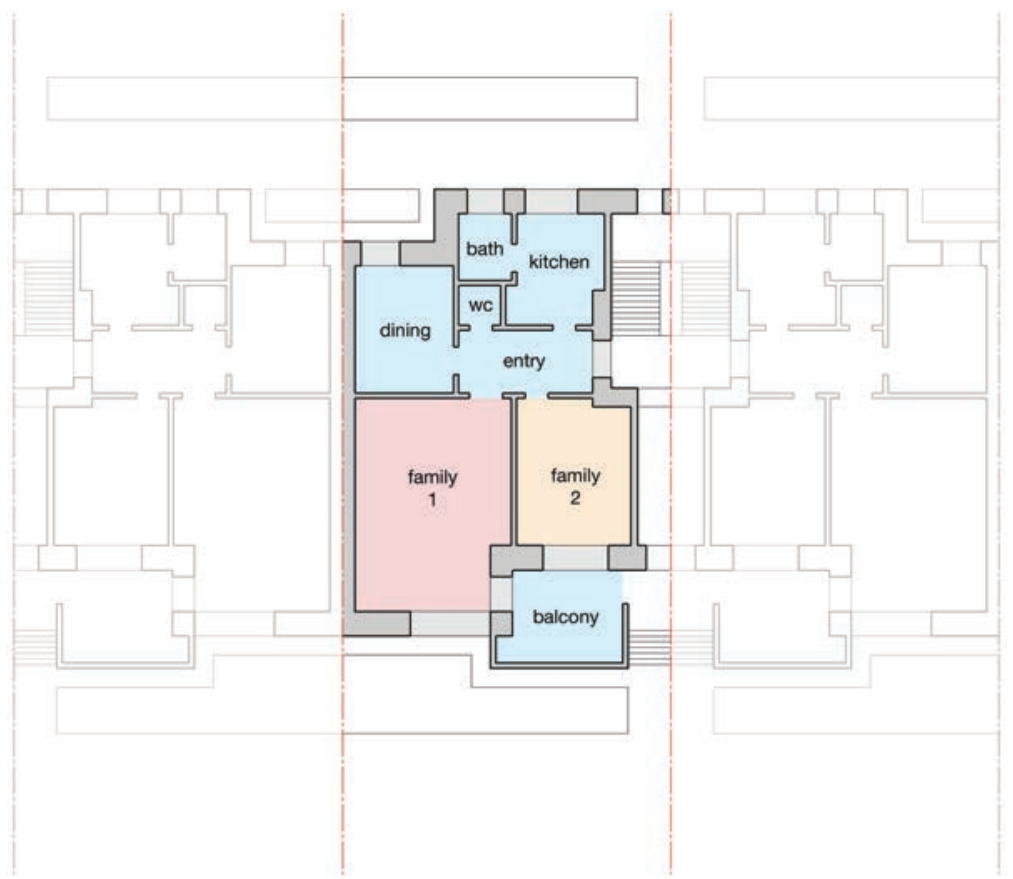

Plate 8. Apartment Type B, a two-room unit, Armenikend test block, Baku, Azerbaijan, 1927. These units were shared by two families, each of whom were given a single private room. Gathering and utility spaces were communal (in blue). Identical Type B units are mirrored on both sides. Architects: Aleksandr Ivanitskii, Anatolii Samoilov, et al. Drawing by the author based on RGALI, f. 2991, o. 1, d. 17, 1. 87. 

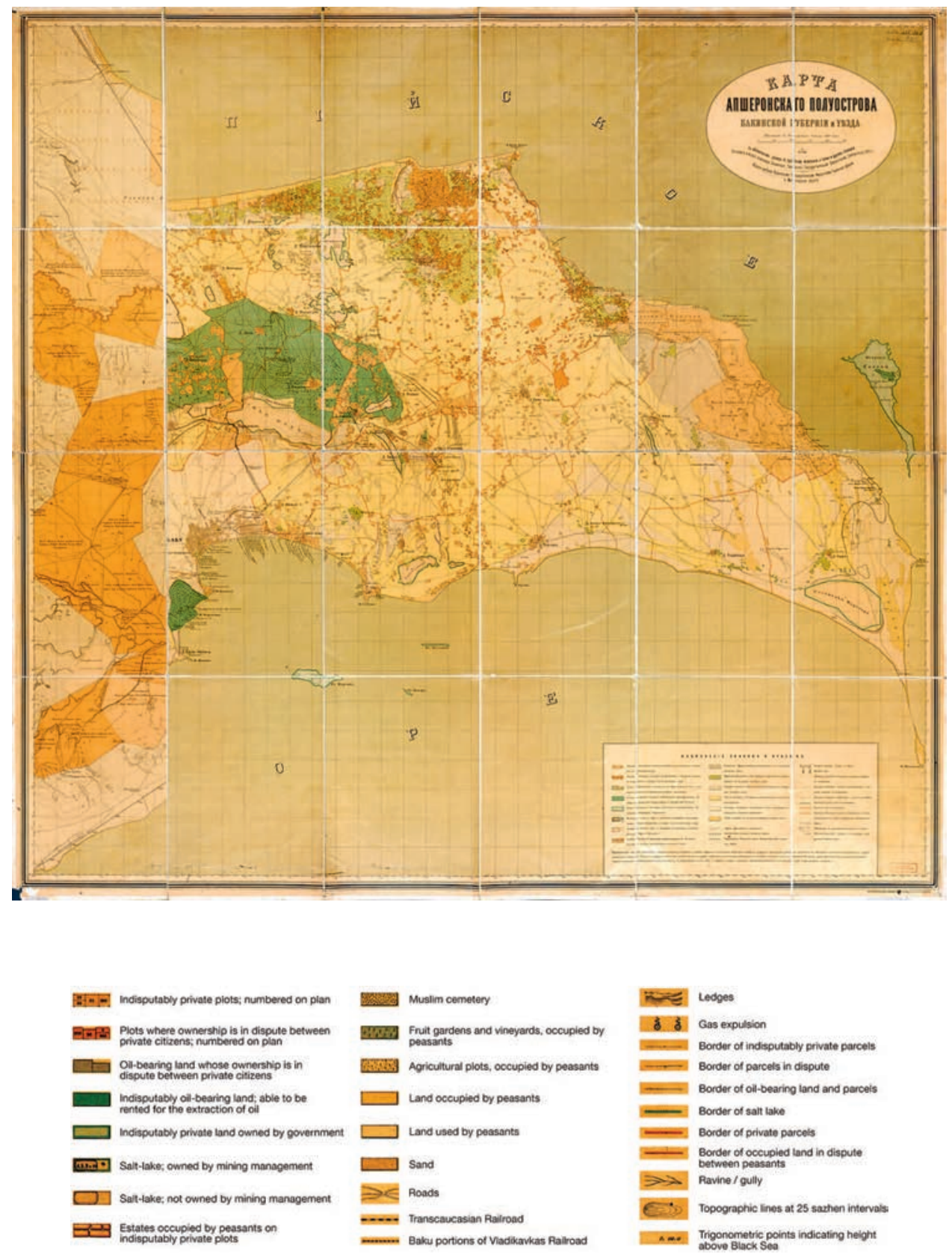

Plate 9. Map of the Apsheron Peninsula in the Baku Governate, 1899. Zemlemier Dmitriev and Kartograficheskoe Zavedenie A. Il'ina, Karta Apsheronskago poluostrova Bakinskoi gubernii $i$ uiezda: s oboznacheniem granits po sudebnomy mezhevaniiu, a takzhe i drugikh sviedienii (Baku: Bakinskoe upravlenie gosudarstvennykh imushchestv, 1899). Library of Congress, Geography and Map Division, G7142.A6G46 1899. D5. Key diagram by the author. 


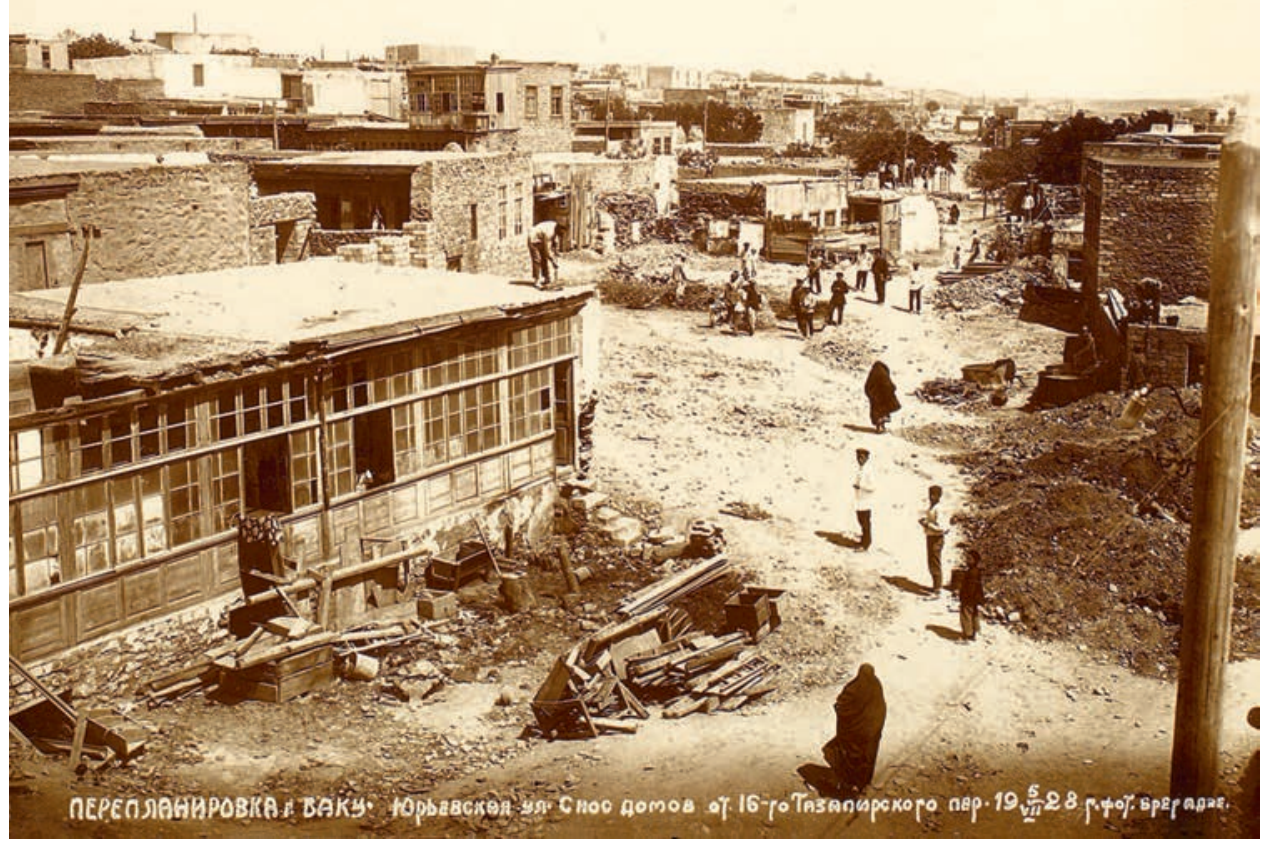

Plate 10. Replanning the City of Baku photo series, documenting the removal of houses along Iur'evskaia Street on July 5, 1928. The elevated vantage point captures the Nagornoe Plateau's character before the street was "punched through.” Photo: L. Bregadze. RGALI, f. 2991, o. 1, d. 17, 1. 125 .

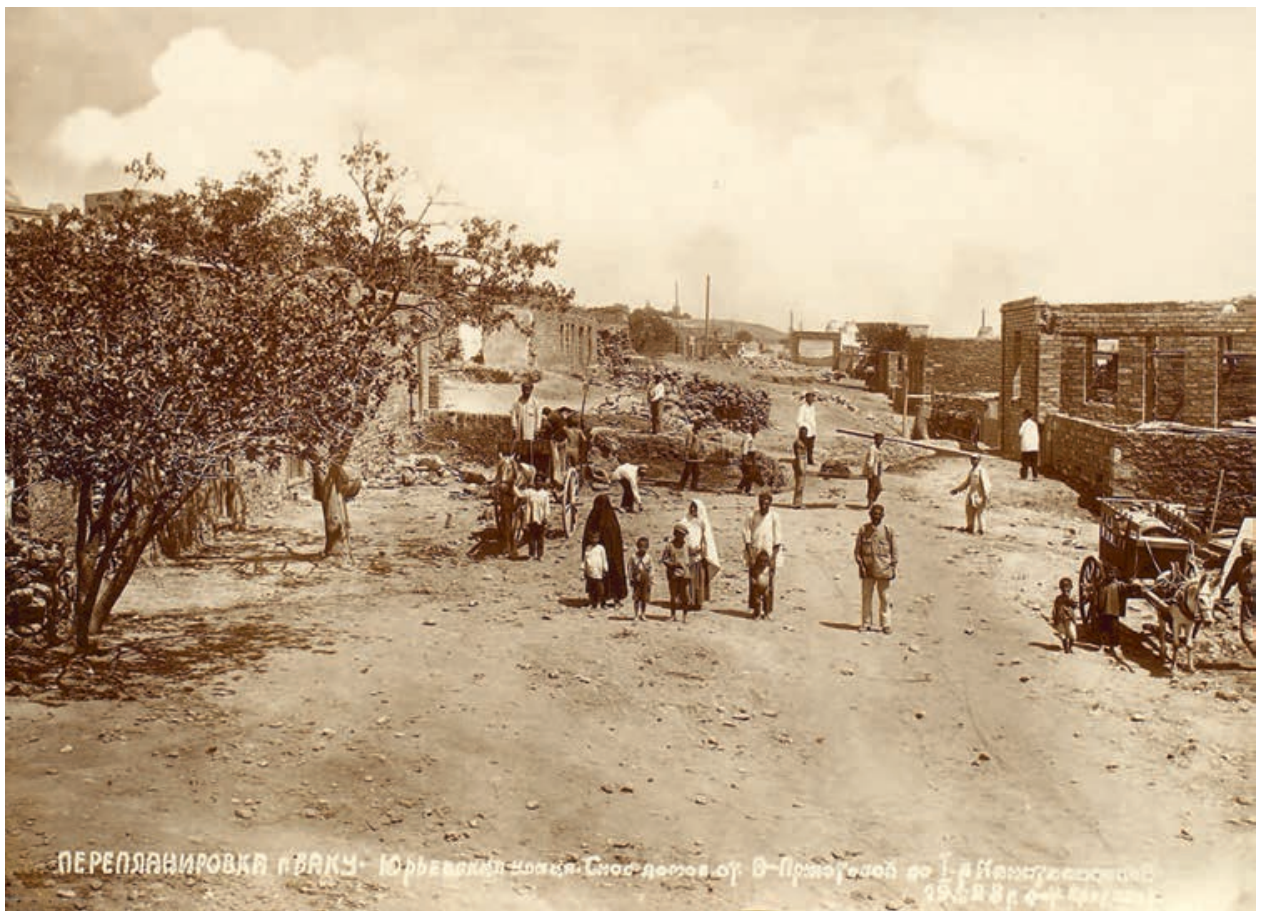

Plate 11. Replanning the City of Baku photo series, documenting the removal of houses along Iur'evskaia Street on July 5, 1928. The photographer often posed his human subjects to mark the scale of intervention. Photo: L. Bregadze. RGALI, f. 2991, o. 1, d. 17, 1. 123. 


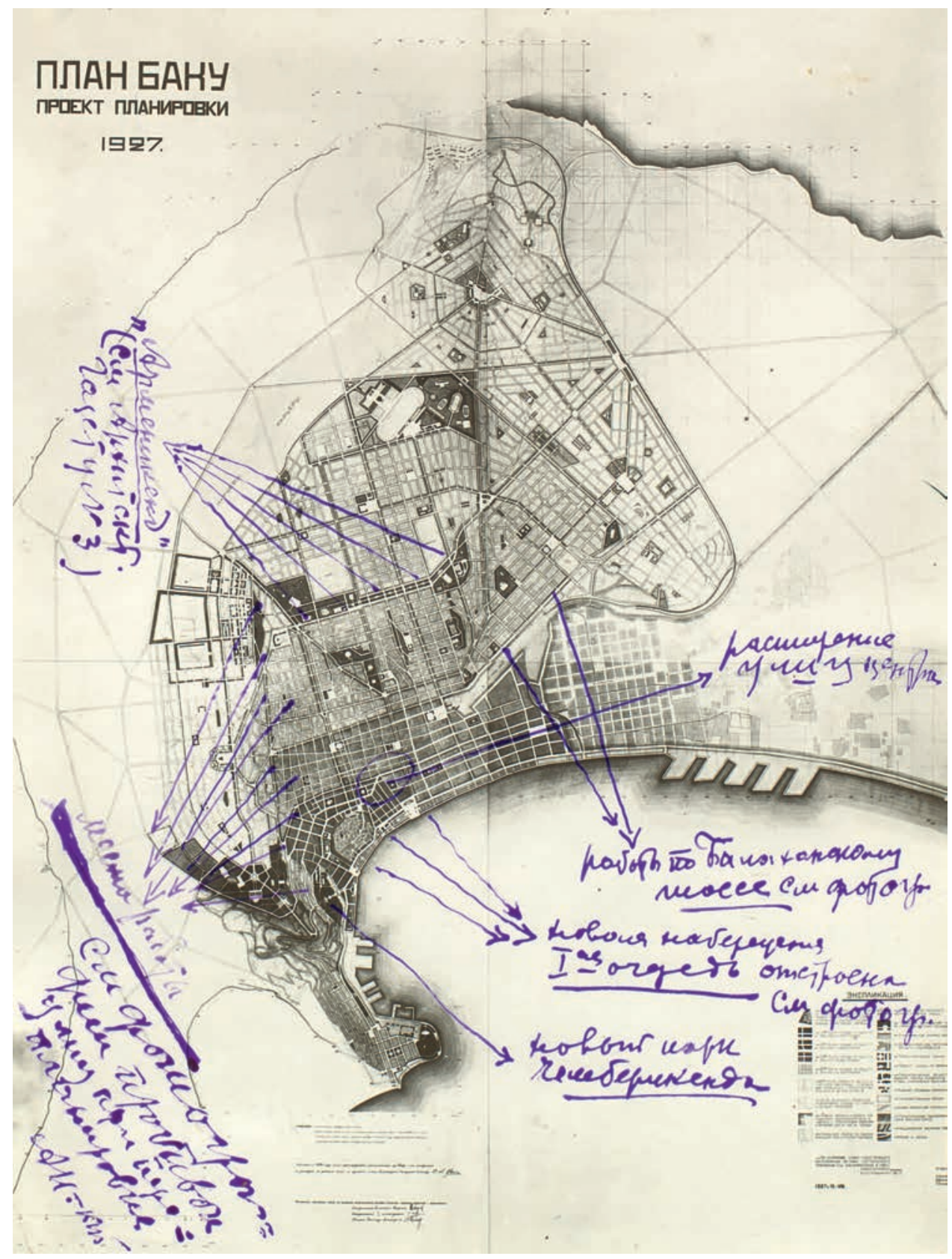

Plate 12. Baku Plan with Ivanitskii's hand notations, 1927. Read clockwise from the lower left-hand corner: places of work [Iur'evskaia]-see photographs of the street punch-through from the replanning-A.I.-skii -; "Armenikend" see [unclear] Newspaper, no. 3; widening of the street in the center; work on Balakhanskoe shosse-see photo; work on the seafront boulevard, 1st phase completed-see photo; new park in Chemberekend. Planners: Aleksandr Ivanitskii, et al. RGALI, f. 2991, o. 1, d. 17, 1. 115 . 


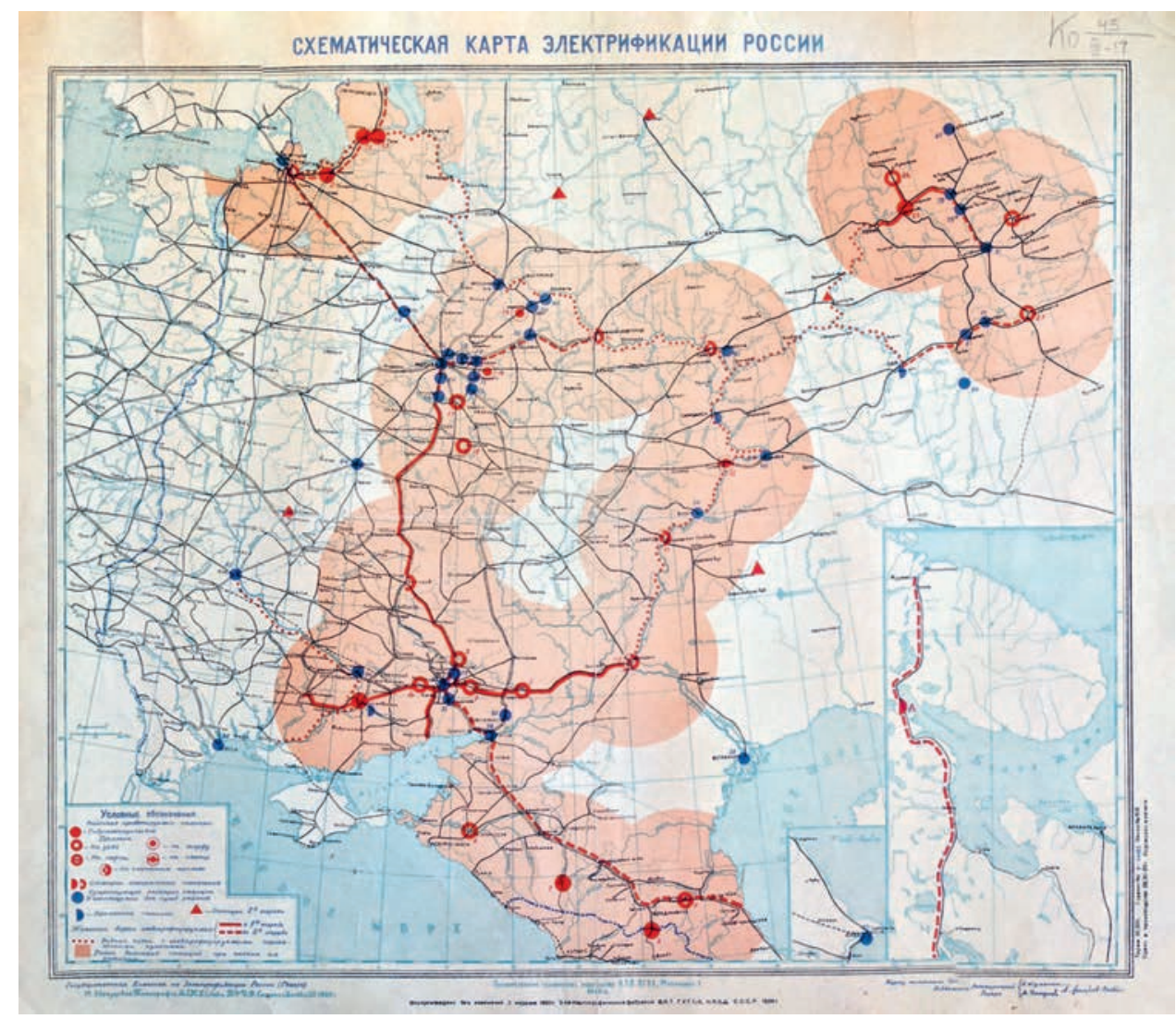

Hydroelectrical station
- Coal-fired station
- Peat-fired station
○ Oil-fired station
Shale-fired station

(6) Mixed fuel station

D Specialized station

Existing electrical station 31 serving the needs of the region

Phase 2 station

Demporary station

Electrified railroads $\quad\left\{\begin{array}{l}--- \text { Phase } 1 \\ -- \text { Phase } 2\end{array}\right.$

... Waterways with electrified transshipment points

Area of electrical service when plan fully developed

Plate 13. GOELRO Plan for the Electrification of Russia, 1920. Planners: Gosplan USSR. RGB/KGR Ko 45/III-17. Key diagram by the author. 


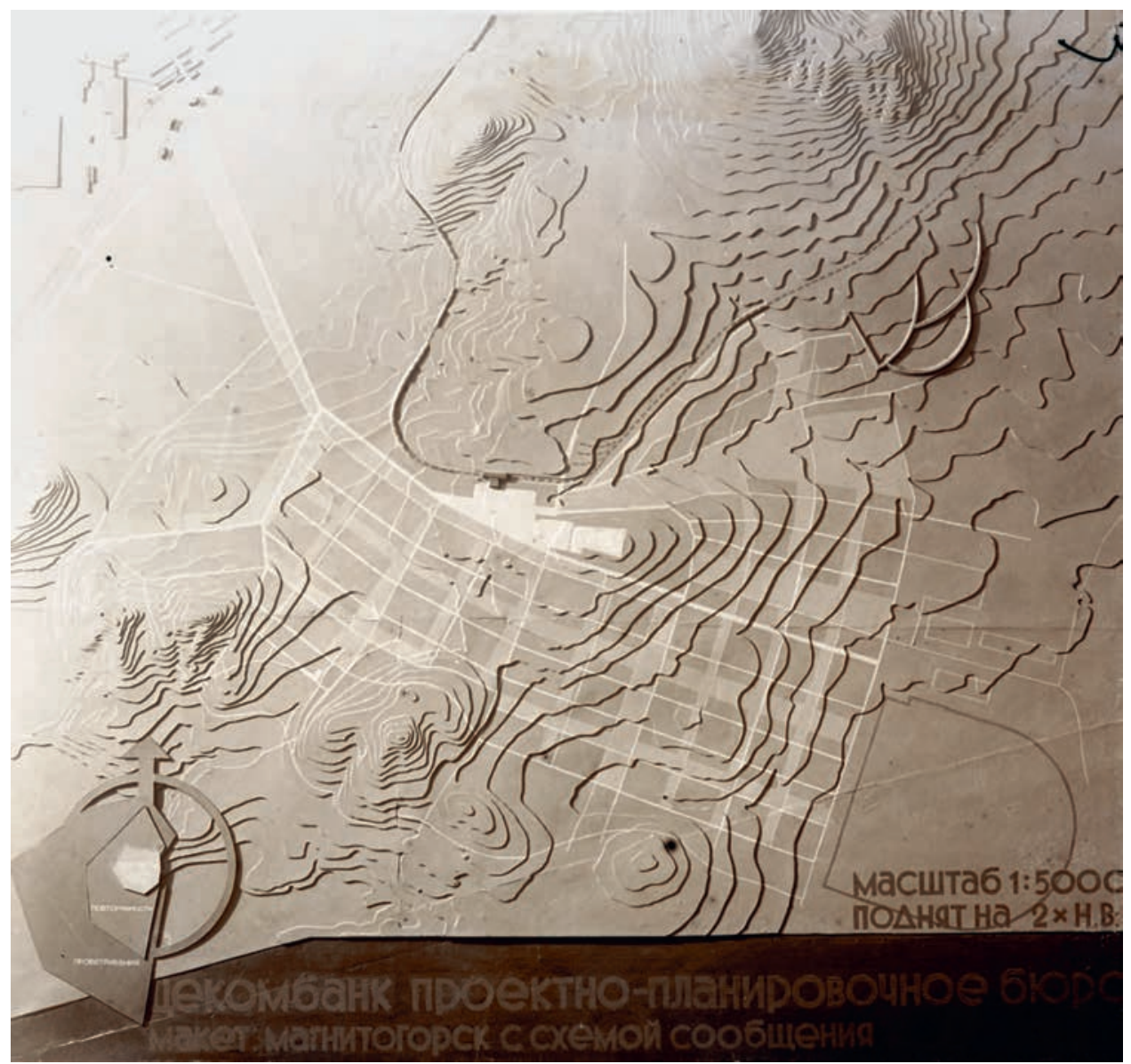

Plate 14. A topographical model of the Left Bank socialist settlement scheme, Magnitogorsk, Russia, 1930. Architects: Tsekombank / Ernst May Brigade. The bowed shape of the housing area is explained by its location between the mine and industrial lake to the north and a row of hills to the south. MUAR, Negative VII-572. 


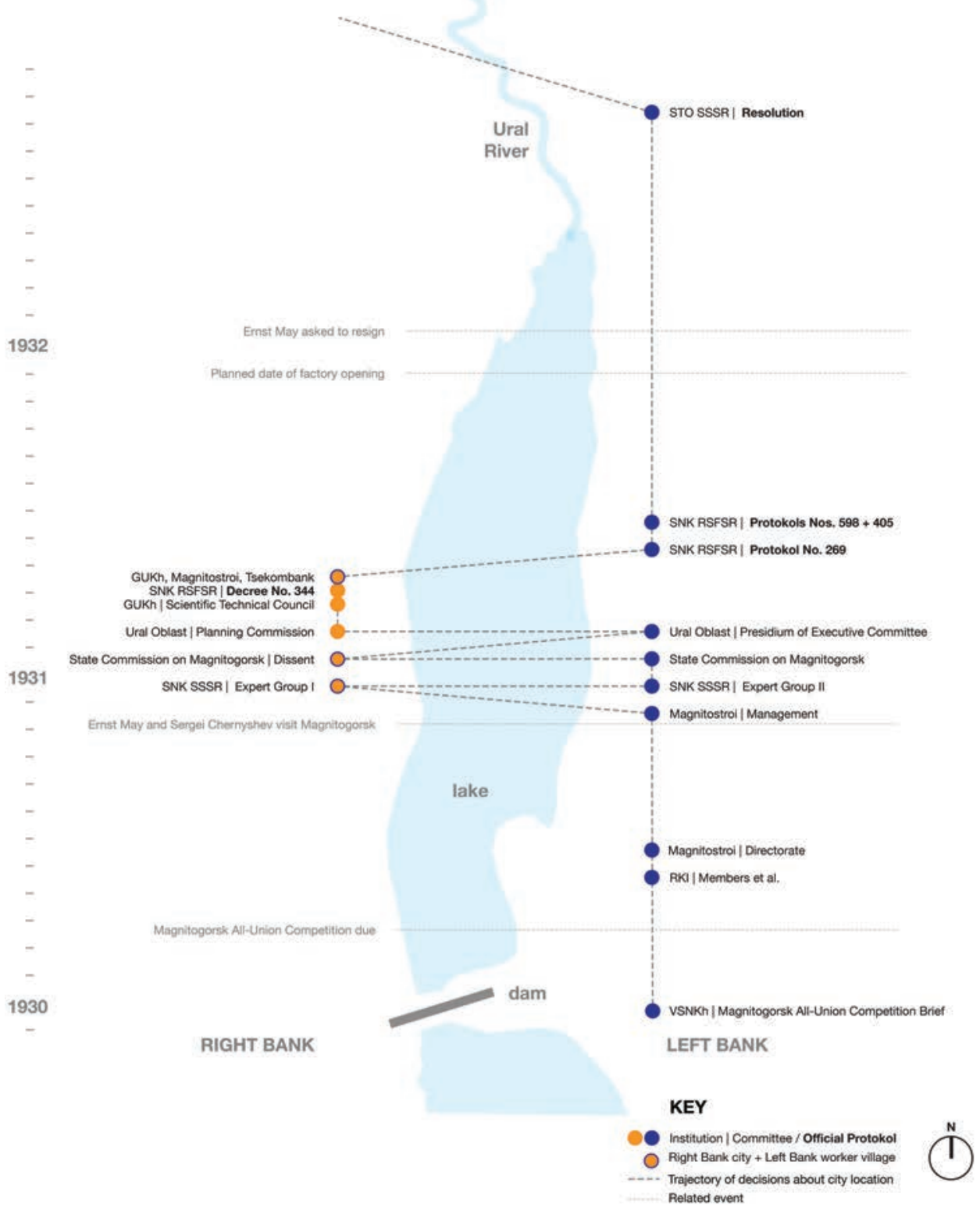

Plate 15. A spatio-temporal map of decisions about the optimal location for the socialist city of Magnitogorsk, 1930-33. From November 1930 to June 1931, the location of the city shifted between the left and right banks seven times. Graphic by the author based primarily on the Magnitogorsk timeline for 1929-1932 at GARF, f. A-314, o. 1, d. 7667, 11. 184-92. 


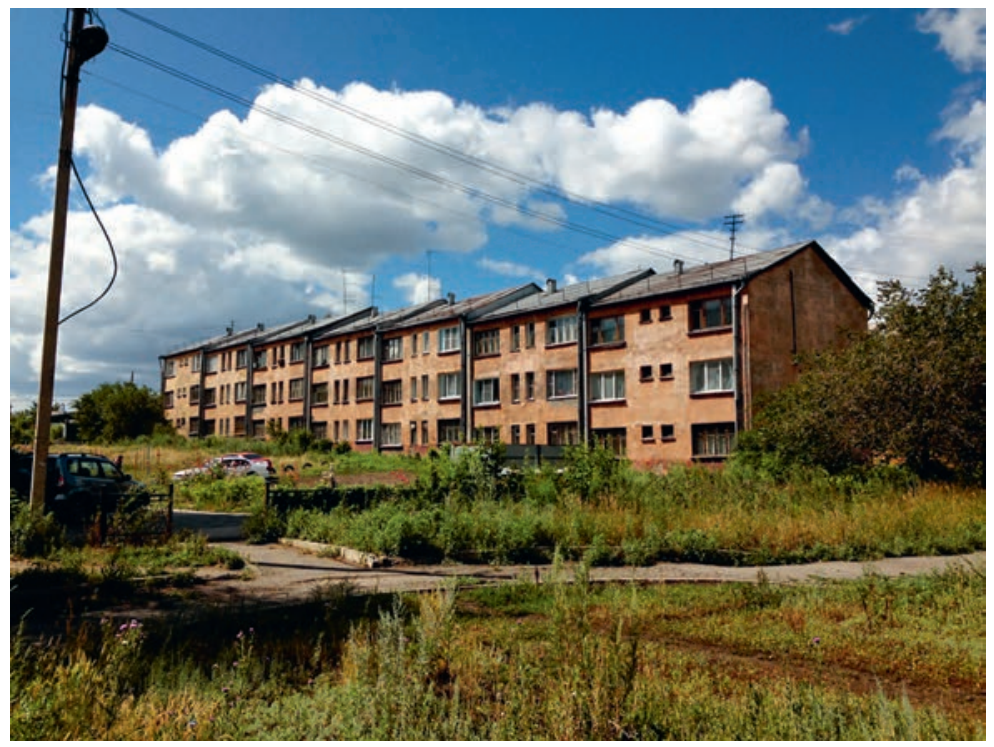

Plate 16. Kirov District “sectional housing,” Magnitogorsk, Russia, 1931-34. Architects: Standartgorproekt / Ernst May Brigade. Photo by the author, 2013.

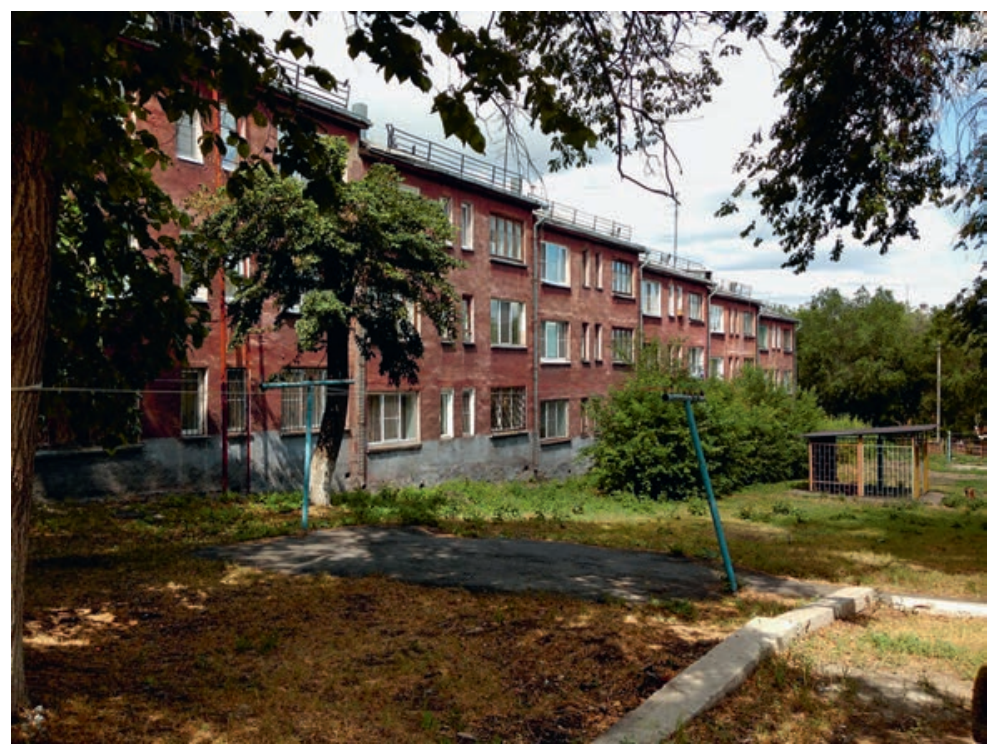

Plate 17. Kirov District INKO-A type housing, Magnitogorsk, Russia, 1931-34. Architects: Standartgorproekt / Ernst May Brigade. Photo by the author, 2013.
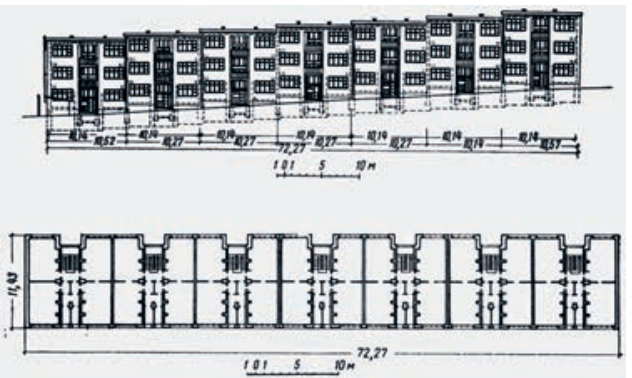

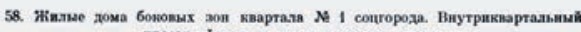
152
Plate 18. Kirov District INKO-A type housing elevation (top) and plan (bottom), Magnitogorsk, Russia, 1931-34. Architects: Standartgorproekt / Ernst May Brigade. V.I. Kazarinova, Magnitogorsk: Opyt sovetskoi arkhitektury (Moscow: Gos. izd. lit. po stroitel'stvu, arkhitekture i stroit. materialam, 1961), 152. 


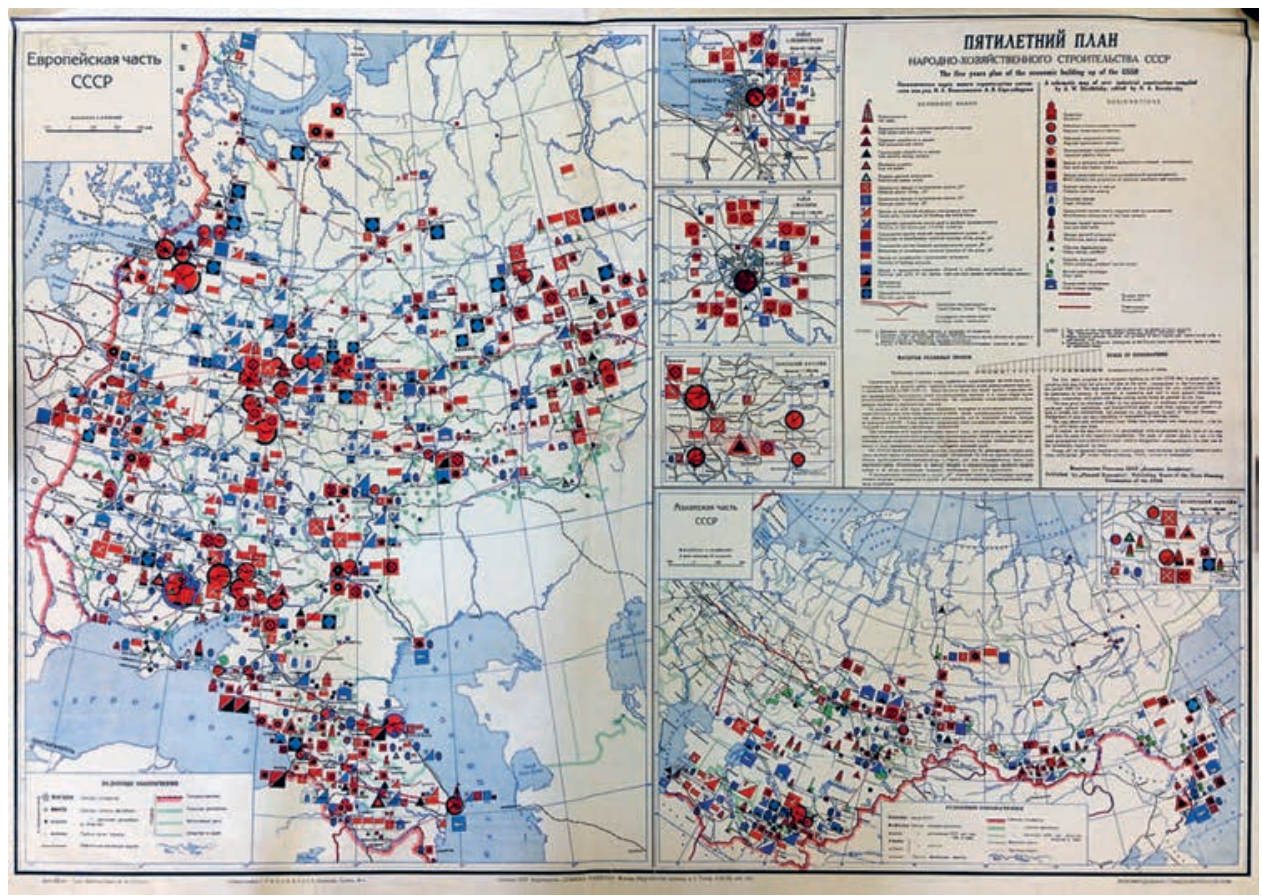

\section{ПЯТИЛЕТНИЙ ПЛАН}

\section{НАРОДНО-ХОЗЯЙСТВЕННОГО СТРОИТЕАЬСТВА СССР}

The five years plan of the economic building up of the USSR

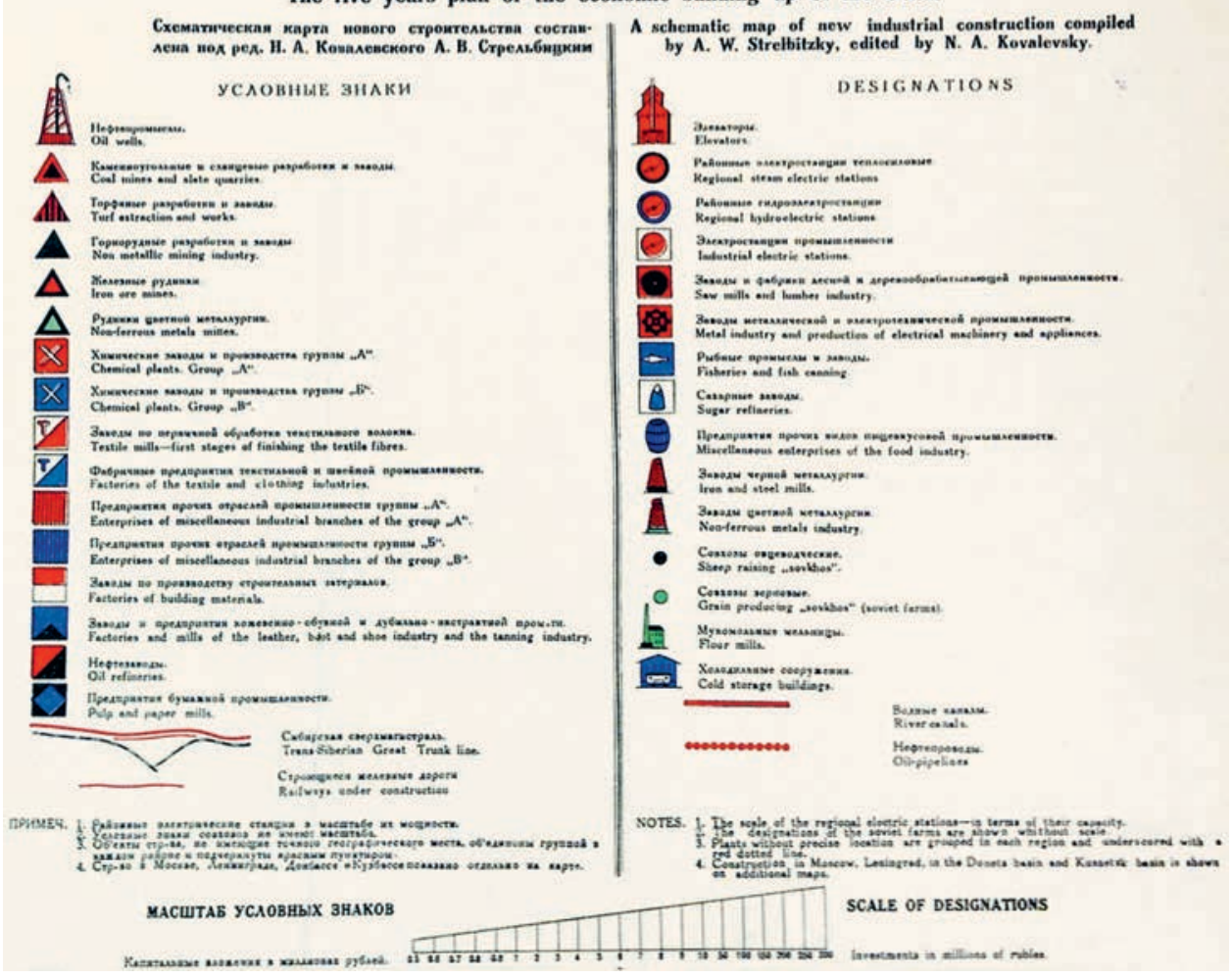

Plate 19. The Five-Year Plan of Economic Development of the USSR map (top) and key detail (bottom), 1930. Planners: Gosplan USSR (Moscow: Izdatel'stvo planovoe khozaistvo, 1930). RGB/KGR Ko 46/VII-37. 


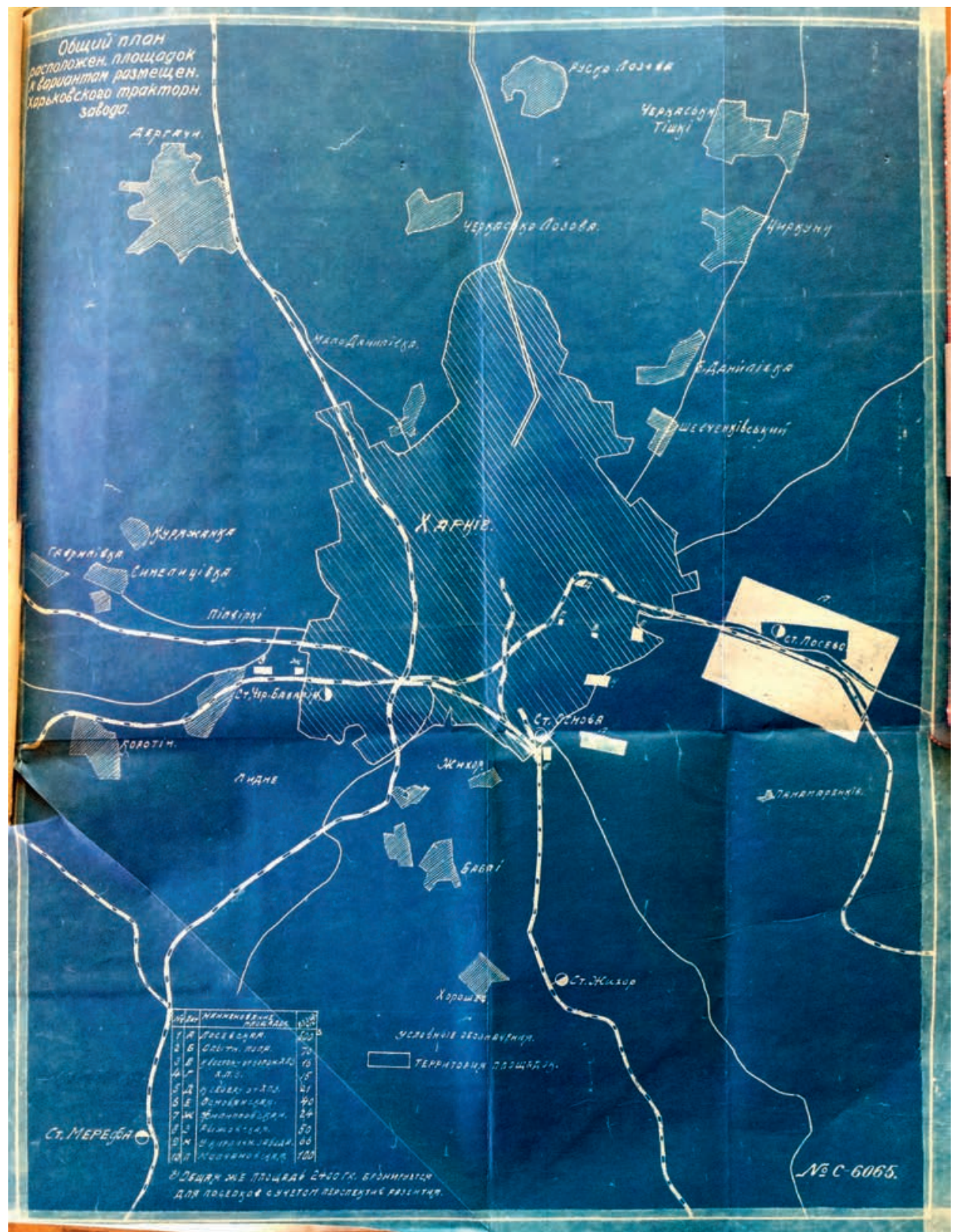

Plate 20. A plan of potential sites for the Kharkiv Tractor Factory, 1929. Report author: Ukrgipromez. The plan shows the city boundary of Kharkiv (hatched) plus major roads and rail lines radiating from the center. Ten potential factory sites are indicated by white rectangles. Losevo, a preexisting station stop on the southeast heavy rail line out of the city (far right), and largest site by far, was ultimately chosen. TsDAMLM Ukrainy, f. 8, po. 1, od. zb. 259, ark. 32 . 


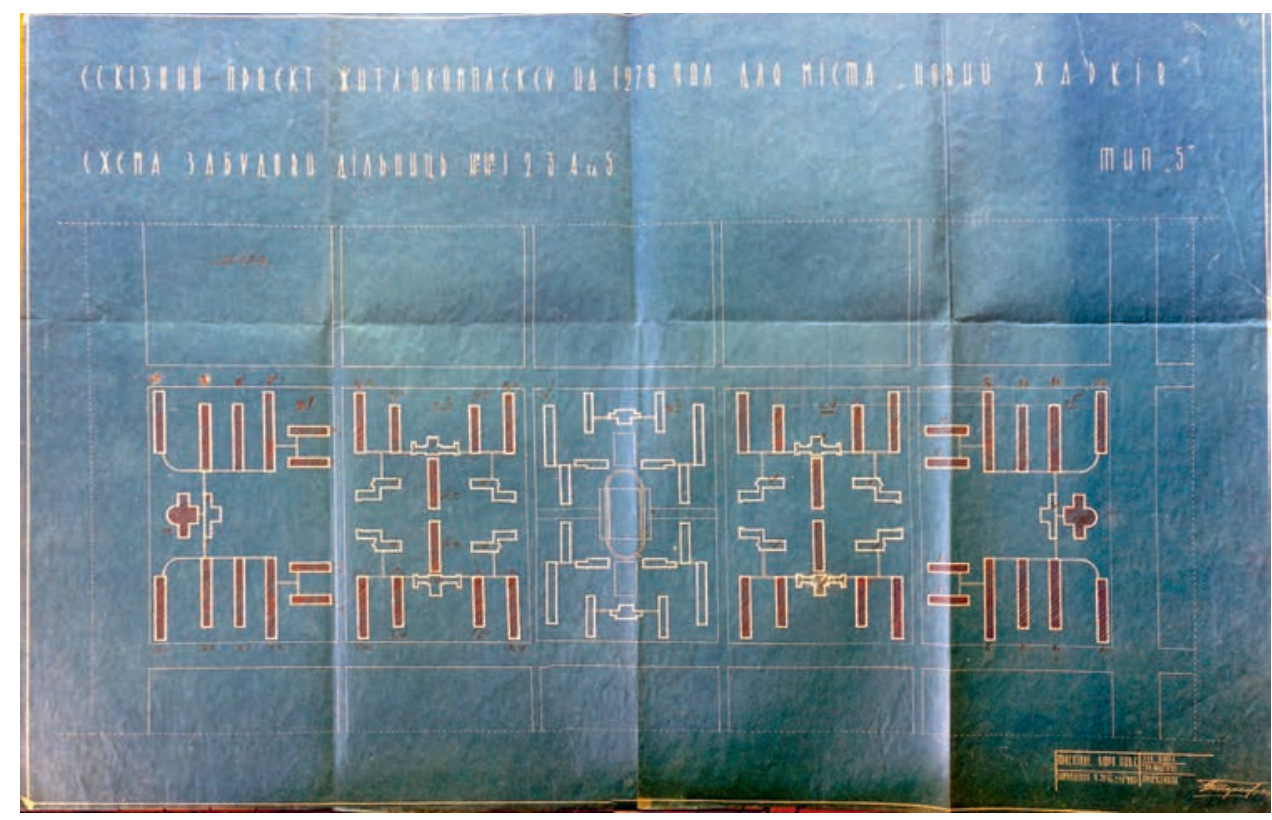

Plate 21. A draft site plan for residential complexes (zhilkombinaty/zhilkompleksy) for 1,276 people, New Kharkiv sotsgorod, Kharkiv, Ukraine, 1931. Architects: Pavel Aleshin, et al. TsDAMLM Ukrainy, f. 8 , po. 1 , od. zb. 260 , ark. 166 .

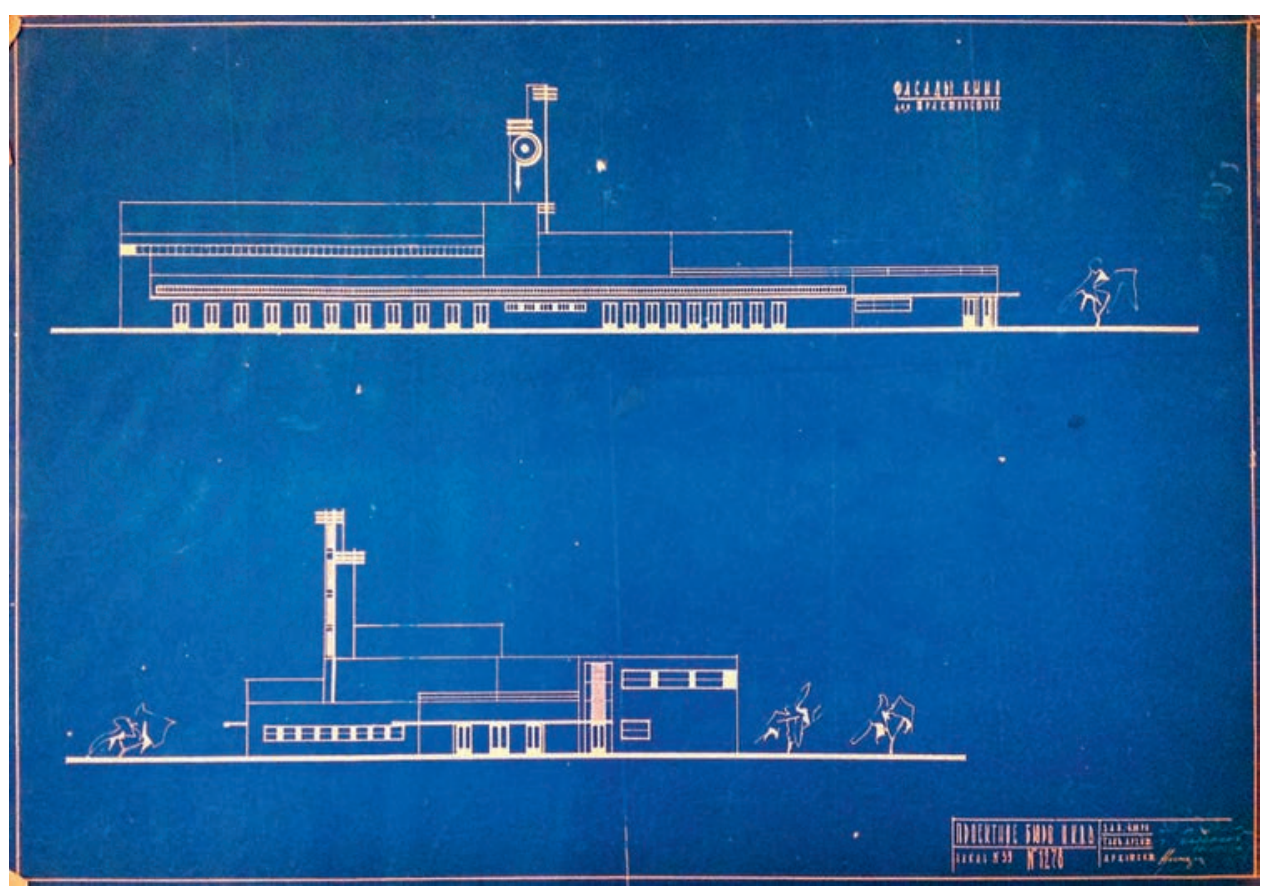

Plate 22. Cinema elevations, New Kharkiv sotsgorod, Kharkiv, Ukraine, 1931. Architects: NKVD Design Bureau, Ukraine. Derzhavna naukova arkitekturno-budivel'na biblioteka imeni V.G. Zabolotnogo. 


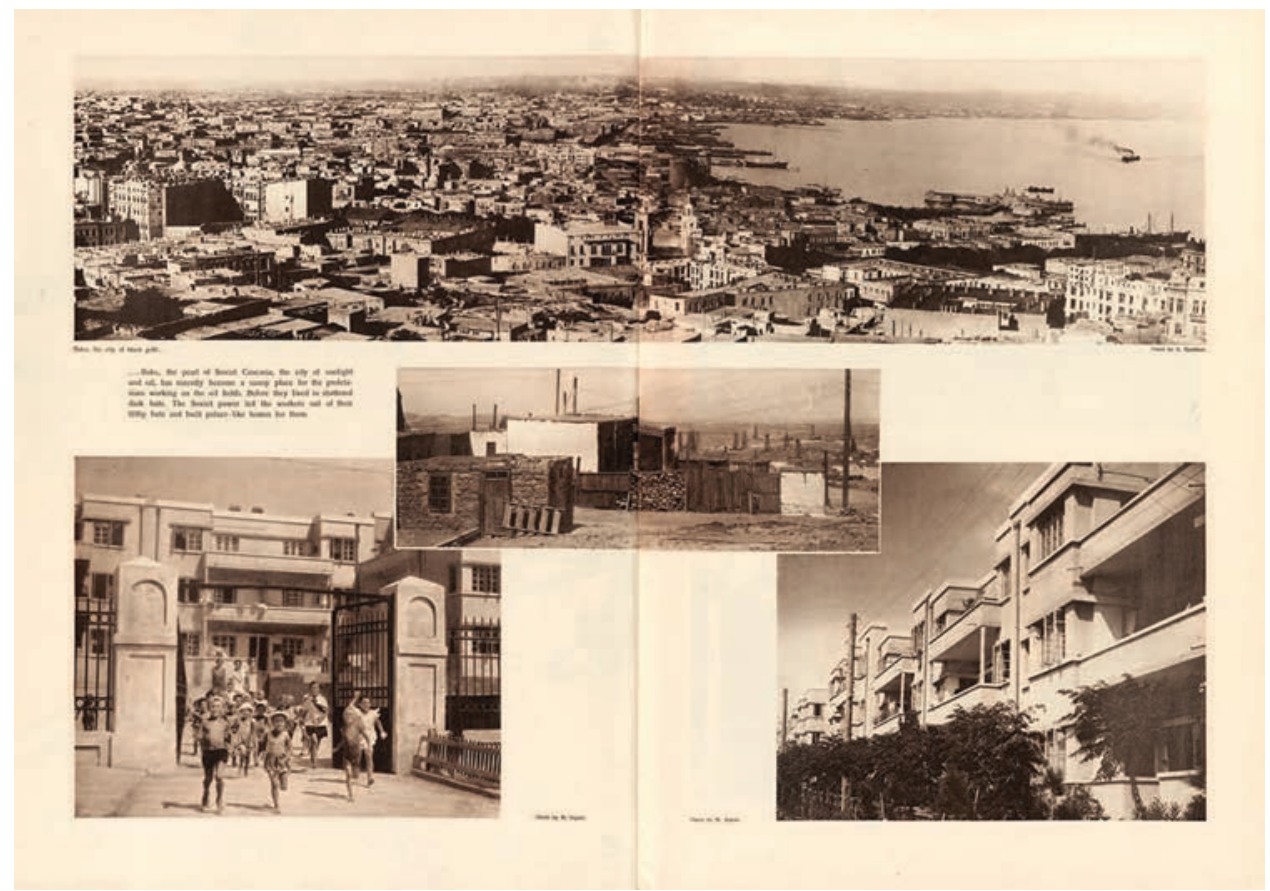

Plate 23. Armenikend Test Block, Baku, Azerbaijan, in the bottom two images, compared to the prerevolutionary city, above. USSR in Construction, no. 12 (1931). Houghton Library, Harvard University.

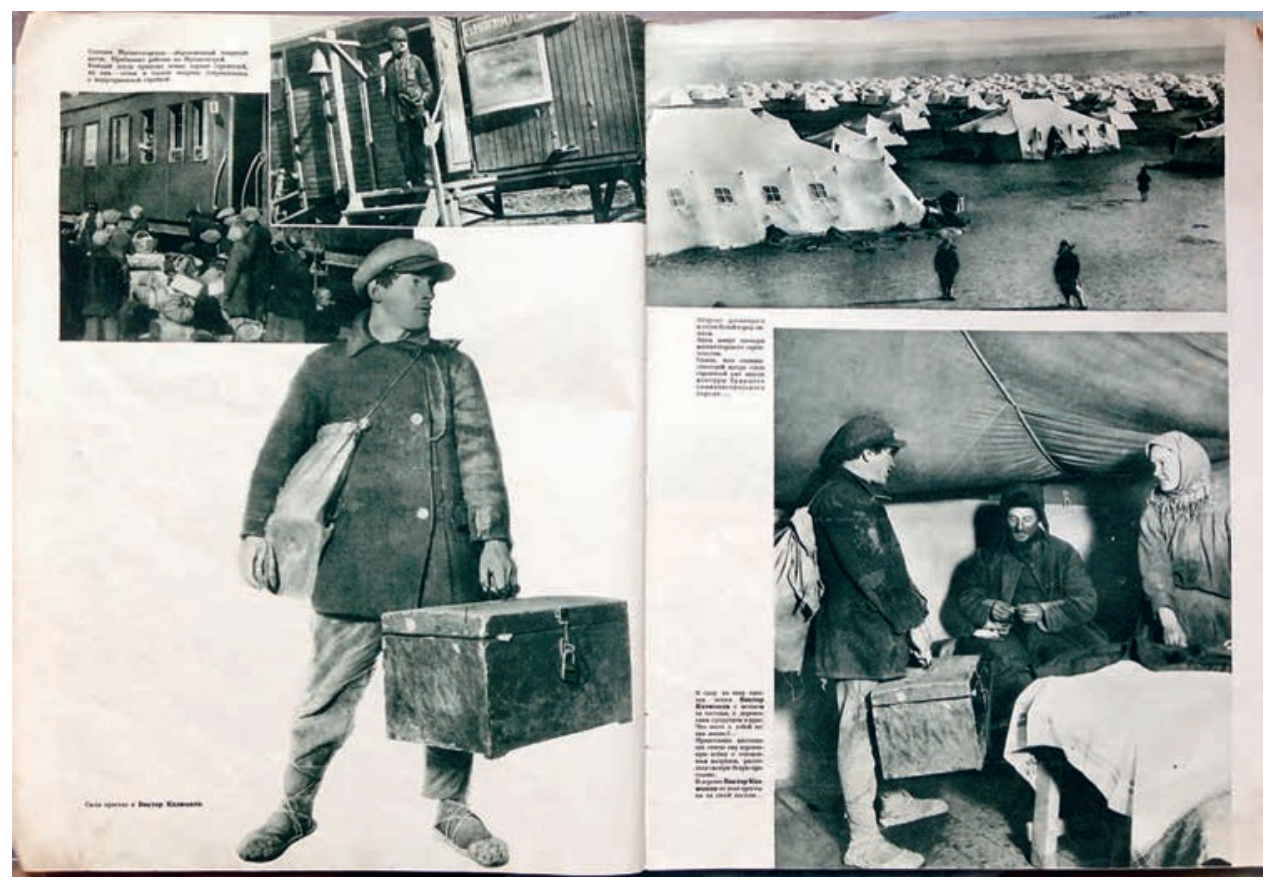

Plate 24. Magnitogorsk issue, with Viktor Kalmykov, "young rural fellow” (molodoi derevenskii

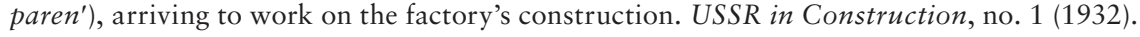
Magnitogorskii kraevedcheskii muzei. 